\title{
EXPRESSÃO DE VEGF-C EM CARCINOMAS ESPINOCELULARES DE BOCA: CORRELAÇÃO COM AS METÁSTASES LINFONODAIS OCULTAS E COM O PROGNÓSTICO DOS PACIENTES
}

\section{Simone Eloiza Sita Faustino}

Dissertação apresentada à Faculdade de Odontologia de Bauru da Universidade de São Paulo, como parte dos requisitos para a obtenção do título de mestre em Odontologia, área de Patologia Bucal. 


\section{EXPRESSÃO DE VEGF-C EM CARCINOMAS ESPINOCELULARES DE BOCA: CORRELAÇÃO COM AS METÁSTASES LINFONODAIS OCULTAS E COM O PROGNÓSTICO DOS PACIENTES}

\section{Simone Eloiza Sita Faustino}

Dissertação apresentada à Faculdade de Odontologia de Bauru da Universidade de São Paulo, como parte dos requisitos para a obtenção do título de mestre em Odontologia, área de Patologia Bucal.

Orientadora: Profa. Dra. Denise Tostes Oliveira. 


\begin{tabular}{|l} 
Faustino, Simone Eloiza Sita \\
F275e Expressão de VEGF-C em carcinomas \\
espinocelulares de boca: correlação com as metástases \\
linfonodais ocultas e com o prognóstico dos \\
pacientes/Simone Eloiza Sita Faustino. -- Bauru, 2007. \\
111p.: il.; 31cm. \\
Dissertação. (Mestrado) -- Faculdade de Odontologia \\
de Bauru. Universidade de São Paulo. \\
Orientadora: Profa. Dra. Denise Tostes Oliveira.
\end{tabular}

Autorizo, exclusivamente para fins acadêmicos e científicos, a reprodução total ou parcial desta dissertação, por processos fotocopiadores e outros meios eletrônicos.

Assinatura:

Data:

Comissão de Ética em Pesquisa do Hospital do Câncer A. C. Camargo.

Protocolo n: $746 / 05$

Data: 29 de novembro de 2005. 


\title{
DADOS CURRICULARES
}

\section{Simone Eloiza Sita Faustino}

\author{
27/01/1978 \\ Nascimento \\ Araraquara - SP \\ $1997-2000$ \\ Curso de Graduação em Odontologia pela Faculdade de \\ Odontologia de Bauru - USP \\ $2000-2000$ \\ Aperfeiçoamento em Ortodontia Preventiva e \\ Interceptativa pela Escola de Aperfeiçoamento Profissional \\ da Associação Paulista de Cirurgiões-Dentistas, \\ Araraquara - SP \\ 2000 - 2001 Aperfeiçoamento em Cirurgia pela Sociedade Paulista de \\ Ortodontia, Botucatu - SP \\ 2001 - 2001 Participação no Programa de Capacitação Profissional em \\ Periodontia da Faculdade de Odontologia de Bauru - USP \\ 2001-2002 Aperfeiçoamento em Periodontia pela Fundação \\ Araraquarense de Ensino e Pesquisa em Odontologia da \\ Universidade Estadual Paulista, Araraquara - SP \\ 2003-2005 Cirurgiã-dentista do Convênio USP/Pittsburgh da \\ Faculdade de Odontologia de Bauru - USP \\ 2005-2007 Curso de Mestrado em Patologia pela Faculdade de \\ Odontologia de Bauru - USP \\ Associação $\quad$ SBPqO - Sociedade Brasileira de Pesquisa Odontológica
}


DEDICATÓRIA

Dedico este trabalho aos meus pais,

Eloiza e Osni 


\section{AGRADECIMENTOS}

\section{A Deus,}

por minha vida, pelas oportunidades e por mostrar-se presente sempre que precisei.

\section{Aos meus pais,}

pelo amor, pela confiança e por me ensinarem a nunca desistir. É difícil Ihes agradecer com palavras, pois não foi somente com elas que vocês me ensinaram a viver. Espero que vocês se orgulhem em me ter como filha, pois eu tenho um imenso orgulho por tê-los como pais. Vocês são o alicerce da minha vida.

\section{Aos meus irmãos, Péricles e Igor,}

pelo amor e por tudo que compartilhamos. Espero que, apesar da ausência física, eu tenha sido um bom exemplo, pois mesmo distante penso em vocês todos os dias, desde quando lhes peguei no colo pela primeira vez.

\section{À minha madrinha Ângela,}

pelos incentivos constantes, pelo apoio nos momentos difíceis, pelo carinho e pelo exemplo profissional.

\section{Aos meus avós, Domingos e Elisa (em memória),}

vocês foram o meu exemplo de honestidade e dignidade. Obrigada por me ensinarem a ter Fé, por tornarem a minha infância mais bela e por todo o cuidado que tiveram comigo.

\section{Ao meu amado Anderson,}

por todo o amor, pela paciência, por querer passar sua vida ao meu lado e por me ajudar a seguir em frente a cada dia. 


\section{AGRADECIMENTOS}

À minha orientadora, Profa. Dra. Denise Tostes Oliveira, você foi muito mais do que minha professora e minha orientadora, você foi acima de tudo minha amiga. Obrigada por todo o conhecimento transmitido, pelos ensinamentos de vida, por confiar em mim, por me acolher nos momentos difíceis e por me incentivar sempre.

Aos professores da Disciplina de Patologia da Faculdade de Odontologia de Bauru Prof. Dr. Alberto Consolaro, Prof. Dr. Luís Antônio de Assis Taveira e Profa. Dra. Vanessa Soares Lara, pelo carinho, pelo exemplo profissional e pelos ensinamentos que me engrandecem desde a graduação.

A todos os professores da Faculdade de Odontologia de Bauru da Universidade de São Paulo que de uma forma ou de outra contribuíram para a minha formação profissional.

Aos funcionários e ex-funcionários da Disciplina de Patologia da Faculdade de Odontologia de Bauru Cristina, Fátima, Oziel, Rodrigo e Valdir, pelo respeito, pelo aconchego nos momentos de tristeza e por serem zelosos e eficientes em suas funções.

Aos colegas de mestrado Ana Carolina, Carlos, Erika, Érika Sinara e Janaína, pelas experiências compartilhadas.

A todos os colegas de pós-graduação, em especial ao Aroldo, à Michele, ao Renato e à Rosário, pela amizade e pelos bons momentos.

Aos meus notáveis amigos Érika Sinara, Fernando, Janaína e Marta, que com suas qualidades ímpares, cada um a sua maneira, me trouxeram conforto e muitas felicidades. A melhor forma que tenho para agradecê-los é oferecer-lhes todo o meu carinho e a minha amizade. Não há palavras para definir o valor que vocês têm para mim. 
À minha amiga Carina, que apesar da distância, nunca se afastou, mantendo o mesmo tratamento doce e amigo.

Às amigas, Ivânia e Edilaine, pelos conselhos e cuidados desde a graduação.

Aos ex-colegas do Convênio USP/Pittsburgh, Christiano, Eliene, Érika, Hebe, Luciana, Marcelo e Patrícia, pelo carinho, por me incentivarem a cursar o mestrado e pelas experiências que vivenciamos.

À Profa. Dra. Odila Pereira Rosa e à Profa. Dra. Salete Moura Bonifácio da Silva, pelos ensinamentos desde a graduação, pela maneira com que me receberam no Convênio USP/Pittsburgh e pelo incentivo que me deram ao querer seguir a carreira acadêmica.

Às funcionárias e ex-funcionárias do Setor de Urgência Odontológica da Faculdade de Odontologia de Bauru: Alice, Ana, Elza, Regina e à querida Maria, pelo respeito, pelo tratamento carinhoso e pelos momentos descontraídos.

A todos os funcionários da Secretaria de Pós-graduação da Faculdade de Odontologia de Bauru, em especial à Giane e à Ana Letícia, pela prontidão, atenção, gentileza e competência.

A todos os funcionários da Biblioteca da Faculdade de Odontologia de Bauru, em nome de Cybelle de Assumpção Fontes, pelo auxílio e orientações no transcorrer do curso.

A todos os funcionários do Serviço de Arquivo Médico do Hospital do Câncer A. C. Camargo, em especial a D. Hirde e ao Luís, por toda consideração, paciência, disponibilidade e presteza com que sempre me atenderam.

Aos funcionários do Arquivo da Anatomia Patológica do Hospital do Câncer A.C. Camargo, Glauber e Marcelo, pelo constante bom humor, pela assistência e pela prontidão na solicitação e localização dos blocos. 
Aos funcionários da Fundação Antônio Prudente, do Hospital do Câncer A.C. Camargo, Carlinhos e Severino pela atenção, presteza e pela confecção dos cortes microscópicos.

À química e farmacêutica Suely Nonogaki, do Setor de ImunoHistoquímica da Fundação Antônio Prudente, do Hospital do Câncer A.C. Camargo, pela atenção, carinho e paciência com que sempre me recebeu, pela segura orientação nas reações imuno-histoquímicas e pelas sugestões apresentadas.

A todos os funcionários da Secretaria do Departamento de Anatomia Patológica do Hospital do Câncer A.C. Camargo, pela gentileza sempre dispensada.

Ao Prof. Dr. Fernando Augusto Soares, chefe do Departamento de Anatomia Patológica do Hospital do Câncer A.C. Camargo e diretor do Centro de Pesquisa da Fundação Antônio Prudente, pela oportunidade de realização desta pesquisa.

Ao Prof. Dr. Gilles Landman, pelas críticas, sugestões e ensinamentos que enriqueceram este trabalho, bem como pela oportunidade e confiança em mim depositada.

Ao Prof. Dr. Luiz Paulo Kowalski, pela sugestão que gerou este trabalho, pela oportunidade de executá-lo, pelo exemplo profissional e pela atenção, paciência e disposição com que sempre me atendeu.

Ao Prof. Dr. André Lopes Carvalho, pela realização da análise estatística, pelos ensinamentos que obtive em nossas reuniões, por toda sua presteza, atenção e paciência, mesmo quando seu tempo estava escasso. Minha admiração e sincera gratidão!

Aos Drs. José Magrin, Mauro Kasuo Ikeda, José Guilherme Vartanian e Mônica Lúcia Rodrigues, médicos do Departamento de Cirurgia de Cabeça e Pescoço e Otorrinolaringologia, do Hospital do Câncer A. C. Camargo, bem como a todos os seus funcionários e residentes, pelo exemplo profissional, pela atenção e pelo respeito. 
Aos pacientes do Hospital do Câncer A. C. Camargo por me fazerem enxergar o valor da vida.

Muito Obrigada! 


\section{AGRADECIMENTOS INSTITUCIONAIS}

À Faculdade de Odontologia de Bauru - Universidade de São Paulo, na pessoa do seu diretor Prof. Dr. Luiz Fernando Pegoraro.

À Comissão de Pós-Graduação da Faculdade de Odontologia de Bauru - USP, na pessoa de sua presidente Profa. Dra. Maria Aparecida de Andrade Moreira Machado.

Ao Curso de Pós-graduação em Patologia da Faculdade de Odontologia de Bauru - USP, na pessoa do seu coordenador Prof. Dr. Luís Antônio de Assis Taveira.

Ao Hospital do Câncer A. C. Camargo e ao Instituto Ludwig de Pesquisa sobre o Câncer, na pessoa do seu diretor Prof. Dr. Ricardo Renzo Brentani.

À CAPES, pelo auxílio pecuniário.

À FAPESP, pelo auxílio pecuniário, imprescindível para a realização desta pesquisa (Processo n²005/04577-4). 
“O sucesso não é final, a falha não é fatal. É a coragem de continuar que importa".

Winston Churchill 


\section{RESUMO}

A forte expressão do fator de crescimento endotelial vascular do tipo -C (VEGF-C) tem sido correlacionada com a presença de metástases linfonodais em carcinomas espinocelulares (CECs) de boca. O objetivo deste estudo consistiu em avaliar a expressão imuno-histoquímica do anticorpo antiVEGF-C, nas células malignas de pacientes com CEC de boca em estádios iniciais, correlacionando-a com a ocorrência de metástases ocultas nos linfonodos cervicais e com o prognóstico dos pacientes. Um total de 87 pacientes com CEC de língua e assoalho de boca, estadiamento clínico I e II, tratados no Departamento de Cirurgia de Cabeça e Pescoço, do Hospital do Câncer A.C. Camargo, São Paulo, no período de 1968 a 2001, foram analisados quanto as características demográficas, clínicas, classificação pelo sistema TNM, tratamento e evolução clínica. Avaliou-se também o índice de malignidade tumoral histopatológico e a expressão imuno-histoquímica de VEGF-C foi comparada entre os CECs de boca sem (pN0) e com (pN+) comprometimento linfonodal (metástases ocultas). As probabilidades de sobrevidas global, livre de doença e específica por câncer dos pacientes com CEC, acumuladas nos períodos de cinco e dez anos, em relação a expressão tumoral de VEGF-C, foram calculadas pelo método de Kaplan-Meier. De sessenta e quatro pacientes submetidos ao esvaziamento cervical eletivo, quatorze deles $(21,9 \%)$ apresentaram comprometimento linfonodal cervical histopatológico (metástase oculta). De acordo com os resultados, não houve correlação estatisticamente significativa entre a expressão de VEGF-C e as principais variáveis demográficas, clínicas, microscópicas e 0 índice histopatológico de malignidade tumoral $(p=0,406)$, bem como com relação a ocorrência de metástases ocultas nos linfonodos cervicais $(p=0,876)$. O único fator de prognóstico significativo para a sobrevida global $(p=0,030)$ foi a ocorrência de metástase oculta comprovada por exame histopatológico. Concluiu-se que a expressão imuno-histoquímica isolada de VEGF-C nas células malignas não influenciou a evolução clínica e o prognóstico dos pacientes com CEC de língua e assoalho de boca nos estádios iniciais (I e II) e, portanto, o esvaziamento cervical eletivo permanece como uma intervenção terapêutica recomendada no tratamento destes pacientes.

Palavras-chave: Neoplasias bucais. Carcinoma espinocelular. Metástase linfática. Prognóstico. 


\begin{abstract}
Expression of vascular endothelial growth factor $-C$ in oral squamous cell carcinoma: correlation with occult lymph node metastasis and patients

prognosis
\end{abstract}

The high expression of vascular endothelial growth factor-C (VEGFC) has been correlated with the presence of lymph node metastasis from oral squamous cell carcinoma (OSCC). The purpose of this study was to evaluate the immunoexpression of VEGF-C antibody in malignant cells of patients in early stages of OSCC, and to correlate it with occult cervical lymph node metastasis and patients prognosis. Eighty seven patients with OSCC of tongue and floor of the mouth, clinical stage I and II, treated at the Department of Head and Neck Surgery and Otorhinolaryngology of Cancer Hospital A. C. Camargo, São Paulo, from 1968 to 2001, were included in this study. It was evaluated the demographical and clinical characteristics, TNM classification, treatment and clinical outcome. The histopathological malignancy index and immunoexpression of VEGF-C and their correlation with OSCC with $(\mathrm{pN}+)$ and without (pNo) positive lymph node (occult metastasis) were also evaluated. The overall and disease-free survival for OSCC patients for five and ten years related to VEGF-C tumor expression were calculated by Kaplan-Meier method. Among 64 patients that were submitted to elective neck dissection, 14 (21,9\%) showed positive histopathological lymph node (occult metastasis). Our results did not show statistically significant difference for VEGF-C expression and main demographical, clinical, microscopical characteristics and histopathological malignancy index $(p=0,406)$, as well as to occult neck metastasis $(p=0,876)$. The occult lymph node metastasis was a prognostic factor for overall survival of patients with OSCC $(p=0,030)$. In conclusion, the immunoexpression of VEGF$C$ in malignant cells per se did not influence the clinical outcome and prognosis of patients with OSCC of tongue and floor of the mouth in early stages (I and II). Therefore, elective neck dissection seems to be a therapeutical recommendation for the treatment of these patients.

Keywords: Mouth neoplasms. Squamous cell carcinoma. Lymphatic metastasis. Prognosis. 


\section{LISTA DE FIGURAS}

Figura 1 - VEGFs conhecidos e seus receptores correspondentes (VEGFRs) (adaptado de AL-RAWI; MANSEL; JIANG ${ }^{3}$, 2005).

Figura 2 - O VEGF-C secretado pelas células tumorais estimula o VEGFR-3 expresso nas células endoteliais linfáticas e assim induz a hiperplasia nos vasos linfáticos peritumorais (em cima à direita). Um aumento da área de superfície linfática aumenta a oportunidade para a entrada da célula tumoral nos vasos linfáticos. O aumento do fluxo linfático também aumenta a disseminação de células tumorais aos linfonodos. Por outro lado, tumores transplantados não induziram uma forte hiperplasia linfática, embora o diâmetro linfático estivesse aumentado em comparação aos tecidos normais (em cima à esquerda). Um aumento do número de células tumorais foi entregue aos linfonodos cervicais dos camundongos portadores de tumores com alta expressão de VEGF-C (embaixo à direita). Chegam mais células neoplásicas aos linfonodos do que as que formarão metástase. As taxas de apoptose e de proliferação das células tumorais não estavam aumentadas nos linfonodos dos tumores com alta expressão de VEGF-C. O anticorpo anti-VEGFR-3 de bloqueio impede a atuação do VEGF-C evitando a hiperplasia dos vasos linfáticos e a disseminação de células tumorais para os linfonodos (abaixo à esquerda). O VEGF-C parece aumentar a ocorrência de metástase linfática pelo aumento da área de superfície dos vasos linfáticos e do fluxo linfático até o momento em que a célula neoplásica entra no vaso linfático (adaptado de HOSHIDA et al. $\left.{ }^{19}, 2006\right)$.

Figura 3 - Localização do front de invasão tumoral com a objetiva de 2,5X em A e aquisição da imagem com a tecla Snap em B no programa Axiovision 4.5 (ZEISS).

Figura 4 - Carcinoma espinocelular de boca com intensa queratinização e padrão de invasão em cordões grossos (A). Em B, observar CEC de boca pouco queratinizado e com padrão de invasão em cordões finos. (HE, aumento original de $63 \mathrm{X}$ em $\mathrm{A}$ e $\mathrm{B})$.

Figura 5 - Algumas figuras de mitose do carcinoma espinocelular de boca (A). Em B, observar a infiltração muscular do CEC de boca. (HE, aumento original de 630X em A e B). 
Figura 6 - Infiltração perineural do CEC de boca (A). Observar no detalhe (B) a presença de cordões finos de células neoplásicas circundando e permeando as células neurais. (HE, aumento original de 63X em A e de 252X em B).

Figura 7 - Expressão imuno-histoquímica fraca do anticorpo antiVEGF-C no CEC de boca (A). Em B, observar o detalhe da área neoplásica demarcada em A. (IHQ, aumento original de $63 \mathrm{X}$ em A e de 252X em B).

Figura 8 - Expressão imuno-histoquímica forte do anticorpo anti-VEGF$C$ no CEC de boca (A). Em B, detalhe da área demarcada em A mostrando células neoplásicas fortemente coradas pelo VEGF-C. (IHQ, aumento original de $63 \mathrm{X}$ em A e de 252X em B).

Figura 9 - Sobrevida global dos pacientes com carcinoma espinocelular de boca de acordo com a expressão de VEGF-C. Porcentagem de sobrevida acumulada pela técnica de Kaplan-Meier.

Figura 10 - Sobrevida livre de doença dos pacientes com carcinoma espinocelular de boca de acordo com a expressão de VEGFC. Porcentagem de sobrevida acumulada pela técnica de Kaplan-Meier.

Figura 11 - Sobrevida específica dos pacientes com carcinoma espinocelular de boca de acordo com a expressão de VEGFC. Porcentagem de sobrevida acumulada pela técnica de Kaplan-Meier.

Figura 12 - Sobrevida global dos pacientes com carcinoma espinocelular de boca de acordo com o comprometimento linfonodal cervical histopatológico. Porcentagem de sobrevida acumulada pela técnica de Kaplan-Meier. 


\section{LISTA DE TABELAS}

Tabela 1 - Distribuição das principais características dos VEGFs em humanos.

Tabela 2 - Graduação de malignidade do front de invasão tumoral de BRYNE et al. ${ }^{11}$.

Tabela 3 - Distribuição de freqüência dos pacientes acometidos pelo carcinoma espinocelular de boca, segundo as características demográficas e os fatores de risco (tabaco e álcool). Hospital do Câncer A. C. Camargo, São Paulo, 1968 a 2001.

Tabela 4 - Distribuição de freqüência dos pacientes acometidos pelo carcinoma espinocelular de boca, segundo as características clínicas e a história clínica. Hospital do Câncer A. C. Camargo, São Paulo, 1968 a 2001.

Tabela 5 - Distribuição de freqüência dos pacientes acometidos pelo carcinoma espinocelular de boca, segundo o tratamento e a evolução clínica. Hospital do Câncer A. C. Camargo, São Paulo, 1968 a 2001.

Tabela 6 - Distribuição de freqüência dos 87 carcinomas espinocelulares de boca, segundo o sistema de graduação de malignidade, do front de invasão tumoral, de BRYNE et al. ${ }^{11}$ Hospital do Câncer A. C. Camargo, São Paulo, 1968 a 2001.

Tabela 7 - Distribuição de freqüência dos carcinomas espinocelulares de boca, segundo a graduação de malignidade tumoral. Hospital do Câncer A. C. Camargo, São Paulo, 1968 a 2001.

Tabela 8 - Distribuição de freqüência dos carcinomas espinocelulares de boca, segundo as características histopatológicas e o comprometimento linfonodal. Hospital do Câncer A. C. Camargo, São Paulo, 1968 a 2001.

Tabela 9 - Distribuição da expressão imuno-histoquímica do anticorpo anti-VEGF-C nos carcinomas espinocelulares de boca, segundo alg variáveis demográficas e clínicas. Hospital do Câncer A. C. Camargo, São Paulo, 1968 a 2001.

Tabela 10 - Distribuição da expressão imuno-histoquímica do anticorpo anti-VEGF-C nos carcinomas espinocelulares de boca, segundo a evolução clínica e as variáveis microscópicas de infiltração neoplásica. Hospital do Câncer A. C. Camargo, São Paulo, 1968 a 2001. 
Tabela 11 - Distribuição da expressão imuno-histoquímica do anticorpo anti-VEGF-C nos carcinomas espinocelulares de boca, segundo o comprometimento linfonodal cervical histopatológico. Hospital do Câncer A. C. Camargo, São Paulo, 1968 a 2001.

Tabela 12 - Distribuição da expressão imuno-histoquímica do anticorpo anti-VEGF-C nos carcinomas espinocelulares de boca, segundo a graduação de malignidade tumoral. Hospital do Câncer A. C. Camargo, São Paulo, 1968 a 2001.

Tabela 13 - Distribuição da expressão imuno-histoquímica do anticorpo anti-VEGF-C nos carcinomas espinocelulares de boca, conforme as sobrevidas global e livre de doença para cinco e dez anos. Hospital do Câncer A. C. Camargo, São Paulo, 1968 a 2001.

Tabela 14 - Distribuição da expressão imuno-histoquímica do anticorpo anti-VEGF-C nos carcinomas espinocelulares de boca, conforme a sobrevida específica por câncer para cinco e dez anos. Hospital do Câncer A. C. Camargo, São Paulo, 1968 a 2001.

Tabela 15 - Distribuição do comprometimento linfonodal cervical histopatológico nos pacientes com carcinoma espinocelular de boca, conforme a sobrevida global para cinco e dez anos. Hospital do Câncer A. C. Camargo, São Paulo, 1968 a 2001. 


\section{LISTA DE ABREVIATURAS, SIGLAS E SÍMBOLOS}

$\mu \mathrm{L}=$ microlitro

$\mu \mathrm{m}=$ micrometro

$\mu \mathrm{M}=$ micromol

BSA = Bovine Serum Albumin (albumina sérica bovina)

$\mathrm{CEC}=$ carcinoma espinocelular

CEC I = carcinoma espinocelular bem diferenciado

CEC II = carcinoma espinocelular moderadamente diferenciado

CEC III = carcinoma espinocelular pouco diferenciado ou indiferenciado

CEC SOE = carcinoma espinocelular sem outras especificações

CECCP = carcinoma espinocelular de cabeça e pescoço

CEC-pN+ = carcinoma espinocelular bem diferenciado com comprometimento linfonodal

CEC-pNO = carcinoma espinocelular bem diferenciado sem comprometimento linfonodal

CECs $=$ carcinomas espinocelulares

CEP = Comissão de Ética em Pesquisa

$\mathrm{cm}=$ centímetro

DAB = Diaminobenzidine Tetrahydrochloride

$\mathrm{ECR}=$ Esvaziamento Cervical Radical

ECRC = Esvaziamento Cervical Radical Clássico

ECRM $(X I)=$ Esvaziamento Cervical Radical Modificado, com preservação do nervo espinhal

ECRM $(\mathrm{XI}+\mathrm{VJ})=$ Esvaziamento Cervical Radical Modificado, com preservação do nervo espinhal e da veia jugular interna.

ECRM I = Esvaziamento Cervical Radical Modificado, com preservação do nervo espinhal. 
ECRM II = Esvaziamento Cervical Radical Modificado, com preservação do nervo espinhal e da veia jugular interna.

ECRM III = Esvaziamento Cervical Radical Modificado, com preservação do nervo espinhal, da veia jugular interna e do músculo esternocleidomastóideo.

ELISA = Enzyme-Linked Immunosorbent Assay

ESOH = Esvaziamento Cervical Supra-Omo-Hióideo

$E U A=$ Estados Unidos da América

Flk-1 = fetal liver kinase-1

Flt-1 = fms-like tyrosine kinase-1

Flt-4 = fms-like tyrosine kinase-4

fms = feline McDonough sarcoma virus

$\mathrm{H}_{2} \mathrm{O}_{2}=$ peróxido de hidrogênio (água oxigenada)

$\mathrm{HE}=$ hematoxilina e eosina

$\mathrm{IHQ}=$ imuno-histoquímica

$\mathrm{kDa}=$ quilodalton

$\mathrm{KDR}=$ kinase insert domain-containing receptor

$\mathrm{M}=\mathrm{mol}$

$\mathrm{mg}=$ miligrama

$\mathrm{mL}=$ mililitro

$\mathrm{mm}=$ milímetro

$\mathrm{mM}=$ milimol

$\mathrm{MN}=$ mononucleares

MOASS = morte sem evidência de recidiva do tumor primário

MOCA = morte decorrente do tumor primário

$\mathrm{MOCl}=$ morte por intercorrência cirúrgica

$\mathrm{N}+=$ presença de linfonodos regionais palpáveis

NO = ausência de linfonodos regionais palpáveis

$N^{0}=$ número 
${ }^{\circ} \mathrm{C}=$ grau Celsius

OMS = Organização Mundial da Saúde

PBS = Phosphate Buffered Saline (solução salina fostatada tamponada)

PDGF = Platelet Derived Growth Factor (fator de crescimento derivado de plaquetas)

pH = concentração hidrogeniônica

PIGF = Placental Growth Factor (fator de crescimento placentário)

PMN = polimorfonucleares

pN+ = presença de metástase em um ou mais linfonodos regionais confirmada microscopicamente

pNO = ausência de metástase em linfonodos regionais confirmada microscopicamente

RNAm = ácido ribonucléico mensageiro

rpm = rotação por minuto

RT-PCR = Reverse Transcription Polymerase Chain Reaction (reação em cadeia da polimerase por transcrição reversa)

SAME = Serviço de Arquivo Médico

SG = sobrevida global

SLD = sobrevida livre de doença

StreptABComplex $=$ streptavidin and biotinylated peroxidase complex

T1 = tumor com até $2 \mathrm{~cm}$ em sua maior extensão, segundo a classificação TNM para tumores malignos de boca

T2 = tumor com mais de $2 \mathrm{~cm}$ e até $4 \mathrm{~cm}$ em sua maior extensão, segundo a classificação TNM para tumores malignos de boca

T3 = tumor com mais de 4cm em sua maior extensão, segundo a classificação TNM para tumores malignos de boca

T4 = tumor com mais de 4cm em sua maior extensão, invadindo estruturas adjacentes, segundo a classificação TNM para tumores malignos de boca

TNM = Tumor Node Metastasis (classificação dos tumores malignos)

$\mathrm{u}=$ unidade 
UICC = Union Internacionale Contre le Cancer (União Internacional Contra o Câncer)

VEGF = Vascular Endothelial Growth Factor (fator de crescimento endotelial vascular)

VEGF-A = fator de crescimento endotelial vascular $-\mathrm{A}$

VEGF-B = fator de crescimento endotelial vascular -B

VEGF-C = fator de crescimento endotelial vascular $-C$

VEGF-D = fator de crescimento endotelial vascular $-D$

VEGF-E = fator de crescimento endotelial vascular $-E$

VEGFR = Vascular Endothelial Growth Factor Receptor (receptor para o fator de crescimento endotelial vascular)

VEGFR-1 = receptor para o fator de crescimento endotelial vascular -1

VEGFR-2 = receptor para o fator de crescimento endotelial vascular -2

VEGFR-3 = receptor para o fator de crescimento endotelial vascular -3

Vivo 000 = vivo e sem evidência da doença 


\section{SUMÁRIO}

1 INTRODUÇÃO

2 REVISÃO DA LITERATURA 7

2.1 EXPRESSÃO DE VEGF-C EM TUMORES SÓLIDOS MALIGNOS 14

2.2 EXPRESSÃO DE VEGF-C NO CARCINOMA ESPINOCELULAR DE BOCA

3 PROPOSIÇÃO

4 CASUÍSTICA E MÉTODOS 33

4.1 POPULAÇÃO DE ESTUDO 35

4.2 REGISTRO DOS DADOS CLÍNICOS 36

4.3 VARIÁVEIS DE ESTUDO 36

4.4 ANÁLISE MICROSCÓPICA 38

4.4.1 Graduação da Malignidade Tumoral 38

4.4.2 Técnica Imuno-Histoquímica 39

4.4.3 Avaliação Imuno-Histoquímica 42

4.5 ANÁLISE ESTATÍSTICA

4.6 AQUISIÇÃO DAS FOTOMICROGRAFIAS 48

4.7 COMISSÃO DE ÉTICA EM PESQUISA (CEP) 48

5 RESULTADOS $\quad 49$

5.1 CASUÍSTICA

5.2 CARACTERIZAÇÃO DEMOGRÁFICA E CLÍNICA DA POPULAÇÃO DE ESTUDO 
5.3 ANÁLISE MICROSCÓPICA 55

5.3.1 Graduação da Malignidade Tumoral 56

5.3.2 Avaliação Imuno-Histoquímica 67

5.4 ANÁLISE DE SOBREVIDA 75

$\begin{array}{lll}6 & \text { DISCUSSÃO } & 79\end{array}$

7 CONCLUSÕES $\quad 89$

REFERÊNCIAS BIBLIOGRÁFICAS 93

$\begin{array}{ll}\text { APÊNDICES } & 101\end{array}$

$\begin{array}{ll}\text { ANEXO } & 109\end{array}$ 
1 - Introdução 


\section{1 - INTRODUÇÃO}

O carcinoma espinocelular (CEC) de boca permanece como o câncer mais freqüente da região de cabeça e pescoço ${ }^{32}$. Apesar dos avanços no diagnóstico e no tratamento, o prognóstico dos pacientes com carcinoma espinocelular de cabeça e pescoço permaneceu sem grandes mudanças na última década. Além disso, progressos no controle local levaram a um aumento na identificação de metástases ${ }^{42}$.

O prognóstico dos pacientes com CEC de boca depende de múltiplos fatores do hospedeiro bem como de características inerentes ao tumor e ao tipo de tratamento ${ }^{5}$. Todavia, o comprometimento dos linfonodos regionais, comprovado por exame histopatológico $(\mathrm{pN}+)$, continua sendo o fator mais importante no estabelecimento do prognóstico dos pacientes com câncer de cabeça e pescoço ${ }^{9,23,25,42}$.

A disseminação metastática dos carcinomas espinocelulares (CECs) de cabeça e pescoço geralmente ocorre através do sistema linfático e os níveis I e || dos linfonodos cervicais são os mais freqüentemente envolvidos ${ }^{4,24,26}$. O nível I dos linfonodos cervicais inclui os linfonodos submentonianos e submandibulares, enquanto o nível II refere-se aos linfonodos da porção superior da veia jugular interna (TNM/UICC $\left.{ }^{31,58}\right)$.

A ocorrência de metástases em carcinomas espinocelulares de língua e assoalho de boca é alta ${ }^{5,43}$, provavelmente, devido à ampla rede vascular, linfática e sangüínea, presente nestas regiões anatômicas. Embora o sistema de estadiamento clínico $\mathrm{TNM}^{31,58}$ continue sendo o mais utilizado para a determinação do prognóstico, este sistema nem sempre é preciso na detecção das metástases linfonodais, muitas das quais permanecem ocultas até serem diagnosticadas pelo exame histopatológico. A incidência de metástases ocultas nos linfonodos cervicais de pacientes com CEC de boca, estádios clínicos I e II, varia de 23,1\% a $42 \%$ e permanece como um forte argumento para a indicação do esvaziamento cervical eletivo nos estádios iniciais de tumores de língua e assoalho de boca ${ }^{5,43}$. 
Essas metástases regionais ocultas $(\mathrm{pN}+)$ são fatores determinantes para a evolução clínica e o prognóstico dos pacientes, por reduzirem a probabilidade de controle da doença, bem como a sobrevida dos mesmos ${ }^{5,23,43,64}$. Entretanto, há uma alta porcentagem de pacientes que não apresentam metástase ao exame histopatológico (pN0) e são submetidos ao esvaziamento cervical eletivo. Nestes, os efeitos cosméticos e funcionais indesejáveis, assim como o aumento da morbidade do esvaziamento linfonodal do pescoço, idealmente, deveriam ser evitados ${ }^{5}$.

Determinar se o esvaziamento cervical eletivo será ou não benéfico ao paciente continua sendo um importante dilema clínico ${ }^{5}$. O reconhecimento de marcadores tumorais que permitam identificar pacientes com tumores biologicamente agressivos e, portanto, de pior prognóstico, tem sido uma busca constante dos pesquisadores. A determinação criteriosa de pacientes com CEC de boca e um maior risco de desenvolverem metástases, principalmente as regionais, com base no conhecimento biológico tumoral, pode ser usada para uma adequada e segura seleção ao esvaziamento cervical.

Com esse intuito alguns marcadores tumorais, como os fatores de crescimento associados à angiogênese e à linfangiogênese, vêm sendo correlacionados a um maior risco de ocorrência de metástase regional $^{7,9,19,23,28,33,34,36,37,38,42,43,54,56,57,60,64,65}$.

Os mediadores químicos responsáveis pela indução e inibição dos processos de angiogênese e linfangiogênese tumoral são produzidos por uma variedade de células, incluindo as células malignas, as células endoteliais, as células do estroma e os leucócitos associados ao tumor ${ }^{6,20,46}$. Dentre os vários indutores endógenos destaca-se o fator de crescimento endotelial vascular (VEGF), cuja expressão associa-se fortemente à angiogênese, ao crescimento progressivo dos tumores sólidos e à ocorrência de metástases linfonodais ${ }^{7,9,19,23,28,33,34,36,37,38,42,43,54,56,57,60,64,65}$.

O fator de crescimento endotelial vascular (VEGF) consiste em uma família de proteínas específicas, altamente potentes, são agentes angiogênicos que atuam no aumento da permeabilidade vascular, no crescimento, proliferação, migração e diferenciação de células endoteliais ${ }^{68}$. Até agora, cinco 
membros dessa família foram identificados em humanos, incluindo o VEGF-A, o VEGF-B, o VEGF-C, o VEGF-D e o PIGF $^{14,21,39,42,48,68}$.

Alguns autores têm mostrado que o VEGF-C consiste em um mediador químico capaz de induzir a linfangiogênese e a dilatação dos vasos linfáticos ao redor do tumor primário, facilitando a disseminação maligna pela ocorrência de metástases ${ }^{19,42,51}$. Além disso, foi sugerido que a expressão de VEGF-C pelas células malignas de alguns tipos de câncer, como o de próstata, mama e pulmão, está fortemente associada a uma maior ocorrência de metástases linfonodais ${ }^{7,34,34.57,65}$. Particularmente, nos carcinomas espinocelulares da região de cabeça e pescoço, incluindo os de boca, a forte expressão de VEGF-C por células tumorais também tem sido fortemente correlacionada com 0 comprometimento metastático linfonodal $^{9,23,28,36,37,42,54,56,64}$.

De acordo com a literatura, o VEGF-C parece constituir uma molécula de ligação entre a linfangiogênese e as metástases regionais em carcinomas espinocelulares de boca. Portanto, a investigação do VEGF-C como fator de prognóstico nesses tumores e sua possível correlação com as metastáses linfonodais, principalmente as ocultas, conforme a proposição do presente estudo, pode contribuir para a adequada indicação de pacientes ao esvaziamento cervical, bem como para o desenvolvimento de novas estratégias antitumorais, baseadas em alvos terapêuticos relacionados aos fatores linfangiogênicos. 


\section{2 - Revisão da Literatura}




\section{2 - REVISÃO DA LITERATURA}

A angiogênese, crescimento e desenvolvimento de novos microvasos sangüíneos ${ }^{16}$, exerce um papel fundamental em muitos processos biológicos; sejam eles fisiológicos, como na proliferação do endométrio, na formação do corpo lúteo e na embriogênese; ou patológicos, como na artrite reumatóide, na retinopatia diabética e nas neoplasias, por exemplo ${ }^{15,41,52}$. Esta formação de novos vasos sangüíneos é essencial para o desenvolvimento e a progressão de tumores sólidos malignos ${ }^{16,17,20,42,63,66}$, pois estes não crescem além de certo tamanho, aproximadamente $1 \mathrm{~mm}^{3}$, até que se estabeleça um suprimento sangüíneo adequado ${ }^{17,40}$. Além de suportar as necessidades metabólicas tumorais, os novos vasos sangüíneos servem como uma rota de escape para as células do tumor primário se disseminarem, ou seja, formarem metástases ${ }^{20}$.

Os reguladores da angiogênese nos tumores, ambos os indutores e os inibidores, são produzidos por uma variedade de células, incluindo as células malignas, as células endoteliais, as células do estroma e os leucócitos associados ao tumor ${ }^{6,20,46}$. Dentre os vários indutores endógenos, destacamse: o fator de crescimento endotelial vascular (VEGF), os fatores de crescimento fibroblásticos ácidos e básicos, a angiogenina, o fator de crescimento do hepatócito, a interleucina 8, as metaloproteinases (MMP), os ativadores do plasminogênio, o fator de crescimento derivado de plaquetas e o fator de crescimento transformador $\beta^{6,20,48}$.

Dentre os fatores de crescimento conhecidos, o VEGF tem sido considerado um regulador central dos processos de angiogênese e linfangiogênese em condições fisiológicas e patológicas ${ }^{14,60}$, por exercer uma função predominante na formação de microvasos sangüíneos e linfáticos ${ }^{45}$.

A família VEGF consiste em várias glicoproteínas, secretadas por leucócitos células endoteliais, células neoplásicas e células do estroma tumoral $^{20,46}$, responsáveis pela regulação de diferentes funções nas células endoteliais, destacando-se: o crescimento, a proliferação, a migração e a 
diferenciação celular. Estas glicoproteínas também atuam na permeabilidade e no tônus vascular, na produção de moléculas vasoativas e no estímulo à quimiotaxia de monócitos ${ }^{63,68}$.

Os principais fatores de crescimento endotelial vascular (VEGFs), em humanos, atualmente incluem cinco membros ${ }^{14,21,39,42,48,68}$.

$\Rightarrow$ VEGF-A: fator de crescimento endotelial vascular -A

$\Rightarrow$ VEGF-B: fator de crescimento endotelial vascular -B

$\Rightarrow$ VEGF-C: fator de crescimento endotelial vascular -C

$\Rightarrow$ VEGF-D: fator de crescimento endotelial vascular -D

$\Rightarrow$ PIGF: fator de crescimento placentário

Os VEGFs são mediadores químicos angiogênicos e linfangiogênicos para o endotélio vascular via receptores tirosino-quinases (RTKs) de alta afinidade. Até a presente data, três receptores tirosino-quinases para VEGFs foram identificados. Eles são relativamente específicos para as células endoteliais e demonstram similaridades estruturais e funcionais à família de receptores do PDGF (Platelet Derived Growth Factor), por apresentarem sete domínios homólogos de imunoglobulina em suas partes extracelulares e um domínio intracelular sinalizador de tirosina-quinase. Estes receptores são chamados de VEGFR-1, VEGFR-2 e VEGFR-3, mas foram originalmente designados de Flt-1 (fms-like tyrosine kinase-1), KDR (kinase insert domain-containing receptor)/Flk-1 (fetal liver kinase-1) e Flt-4 (fms-like tyrosine kinase-4) respectivamente. Nos homens adultos, o VEGFR-1 e o VEGFR-2 são expressos principalmente no endotélio vascular sangüíneo, enquanto o VEGFR-3 apresenta-se, predominantemente, no endotélio linfático dos tecidos adultos normais ${ }^{14,39,42,48,53,60,68}$.

As principais características da família VEGF incluindo: isoformas, localização cromossômica, receptor correspondente e ligação vascular (sangüínea ou linfática) foram cuidadosamente agrupados na Tabela 1. 
TABELA 1 - Distribuição das principais características dos VEGFs em humanos.

\begin{tabular}{|c|c|c|c|c|}
\hline $\begin{array}{c}\text { Fator de } \\
\text { crescimento }\end{array}$ & Isoforma & Cromossomo & Receptor & $\begin{array}{l}\text { Ligação } \\
\text { vascular }\end{array}$ \\
\hline VEGF-A & $\begin{array}{l}\text { VEGF }_{121} \\
\text { VEGF }_{145} \\
\text { VEGF }_{165} \\
\text { VEGF }_{189} \\
\text { VEGF }_{206}\end{array}$ & $6 p$ & $\begin{array}{l}\text { VEGFR-1 } \\
\text { VEGFR-2 } \\
\text { VEGFR-2 } \\
\text { VEGFR-2 } \\
\text { VEGFR-2 }\end{array}$ & $\begin{array}{l}\text { Endotélio } \\
\text { sangüíneo }\end{array}$ \\
\hline VEGF-B & $\begin{array}{l}\text { VEGF-B } 167 \\
\text { VEGF-B } \\
\end{array}$ & $11 q$ & $\begin{array}{l}\text { VEGFR-1 } \\
\text { VEGFR-1 }\end{array}$ & $\begin{array}{l}\text { Endotélio } \\
\text { sangüíneo }\end{array}$ \\
\hline VEGF-C & VEGF-C & $4 q$ & $\begin{array}{l}\text { VEGFR-2 } \\
\text { VEGFR-3 }\end{array}$ & $\begin{array}{c}\text { Endotélio } \\
\text { sangüíneo } \\
\text { Endotélio } \\
\text { linfático }\end{array}$ \\
\hline VEGF-D & VEGF-D & $X p$ & $\begin{array}{l}\text { VEGFR-2 } \\
\text { VEGFR-3 }\end{array}$ & $\begin{array}{c}\text { Endotélio } \\
\text { sangüíneo } \\
\text { Endotélio } \\
\text { linfático }\end{array}$ \\
\hline PIGF & $\begin{array}{l}\text { PIGF-1 } \\
\text { PIGF-2 } \\
\text { PIGF-3 }\end{array}$ & $14 q$ & $\begin{array}{l}\text { VEGFR-1 } \\
\text { VEGFR-1 } \\
\text { VEGFR-1 }\end{array}$ & $\begin{array}{l}\text { Endotélio } \\
\text { sangüíneo }\end{array}$ \\
\hline
\end{tabular}

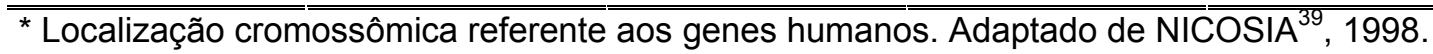

O VEGF-A, também conhecido como VPF (Vascular Permeability Factor), apresenta cinco isoformas descritas até o presente: VEGF ${ }_{121}, V_{E G F} F_{145}$, $V_{E G F} 165, V E_{189}$ e VEGF 206 . Estas isoformas se ligam a dois receptores tirosino-quinases: VEGFR-1 e VEGFR-2 ${ }^{14,21,39,41,42,48,68}$. A isoforma 121 tem alta afinidade pelo VEGFR-1, enquanto as outras apresentam afinidade pelo VEGFR-2 ${ }^{39}$, conforme elucidado pela Figura 1. Através destes receptores, o VEGF-A estimula a migração e a proliferação de células endoteliais de artérias, veias e microvasos, bem como a angiogênese in vivo e in vitro ${ }^{14,39,41,48}$. O VEGF-A promove a degradação balanceada da matriz extracelular ao redor dos brotos endoteliais e aumenta a permeabilidade de vênulas às proteínas circulantes, incluindo o fibrinogênio, o que facilita a deposição perivascular de fibrina, a qual também potencializa a angiogênese. Além disso, através de sua capacidade de induzir o óxido nítrico, o VEGF-A, também pode mediar a vasodilatação e o aumento do fluxo sangüíneo que precede a angiogênese ${ }^{39}$. Estes achados revelaram a importância da sinalização promovida pelos VEGFs na biologia da progressão tumoral ${ }^{60}$. 
O VEGF-B, anteriormente chamado de VRF (VEGF-related factor), está presente em uma variedade de órgãos normais e é particularmente abundante nos músculos esqueléticos e cardíacos. Há duas isoformas de VEGF-B: 167 e 186. O VEGF 167 é uma proteína ligante de heparina que, similarmente ao VEGF 189 e ao VEGF 206 , permanece associado com a célula ou à matriz extracelular e não é liberado em meio de cultura a menos que as células sejam tratadas com heparina. Em contrapartida, o VEGF 186 é facilmente secretado e difundido livremente. O VEGF-B estimula a proliferação de células endoteliais pelo receptor VEGFR-1 (Tabela 1 e Figura 1) e parece ser necessário na manutenção das funções normais do tecido cardíaco adulto, mas não no desenvolvimento e na vasculogênese cardiovascular ${ }^{39,48}$.

O VRP (VEGF-related protein), atualmente conhecido como VEGF$\mathrm{C}$, é produzido como um pró-peptídeo que é proteoliticamente clivado a uma molécula de $21 \mathrm{kDa}^{27}$. Diferentemente das isoformas VEGF-A, VEGF-B e PIGF, ele não se liga à heparina. O VEGF-C aumenta a permeabilidade vascular e estimula a migração e proliferação de células endoteliais, mas numa concentração muito superior a do VEGF-A ${ }^{27}$. A molécula de VEGF-C liga-se ao receptor de tirosina-quinase Flt-4, que hoje é chamado de VEGFR-3, bem como ativa o receptor VEGFR-2/KDR ${ }^{27,39,48}$. O processamento proteolítico de VEGF-C gera um pró-VEGF-C e um VEGF-C completamente processado, ambos têm afinidade pelo VEGFR-3, mas somente o VEGF-C completamente processado pode ligar-se ao VEGFR-2 $2^{22,48}$ (Tabela 1 e Figura 1). Moléculas de VEGF-C atuam na linfangiogênese durante o desenvolvimento embrionário e mantendo a diferenciação do endotélio linfático em adultos ${ }^{27,48}$. O VEGF-C tem sido correlacionado a alguns tumores humanos, incluindo os de mama, colo uterino, pulmão, próstata e de cabeça e pescoço $^{7,9,19,23,28,34,35,36,37,42,54,56,57,60,64,65}$.

Com relação ao VEGF-D, também chamado de FIGF (c-fos-induced growth factor), consiste em uma molécula $48 \%$ idêntica ao VEGF-C. Ambos os fatores têm extensões terminais longas de $-\mathrm{NH}_{2}$ e $-\mathrm{C}$, o que coloca estes fatores de crescimento a parte, como uma subfamília de proteínas relacionadas ao VEGF. Nos adultos, ele é principalmente encontrado no músculo esquelético, no coração, no pulmão e no intestino ${ }^{39,48}$. Assim como o VEGF-C 
seus receptores são o VEGFR-2 e o VEGFR-3 e por meio destes estimula a proliferação de células endoteliais ${ }^{39,48}$ (Tabela 1 e Figura 1). De acordo com o trabalho de O-CHAROENRAT; RHYS-EVANS; ECCLES ${ }^{42}$, em 2001, a expressão de VEGF-D em carcinomas espinocelulares de cabeça e pescoço foi significativamente menor do que nos tecidos normais utilizados como controle.

Outro fator de crescimento da família VEGF, conhecido como PIGF, apresenta $42 \%$ da sua seqüência de aminoácidos idênticos ao VEGF-A ${ }^{48}$. Ele se une com alta afinidade ao VEGFR-1, mas não ao VEGFR-2 (Tabela 1 e Figura 1). A expressão deste fator é típica na placenta ${ }^{39,48}$ e não é observada na maioria dos tecidos adultos normais ${ }^{39}$, entretanto, no artigo de revisão de Roskoski $^{48}, 2007$, o autor cita uma série de trabalhos nos quais as isoformas de PIGF são expressas tanto por células normais do coração, músculo esquelético, retina e pele, quanto por células malignas de mama, estômago, próstata e pulmão.

Além dos VEGFs conhecidos em humanos, outro fator de crescimento endotelial vascular também foi descrito na literatura, o VEGF-E, codificado por um Orf parapoxvirus. Este fator foi identificado no genoma de duas linhagens virais que afetam cabras, ovelhas e ocasionalmente humanos, nos quais as lesões são caracterizadas por extensa proliferação microvascular na pele ${ }^{14,48}$. Além disso, o VEGF-E estimula a quimiotaxia, proliferação e brotamento de células endoteliais em cultura ${ }^{48}$, por meio da sua atuação sobre o receptor VEGFR-2.

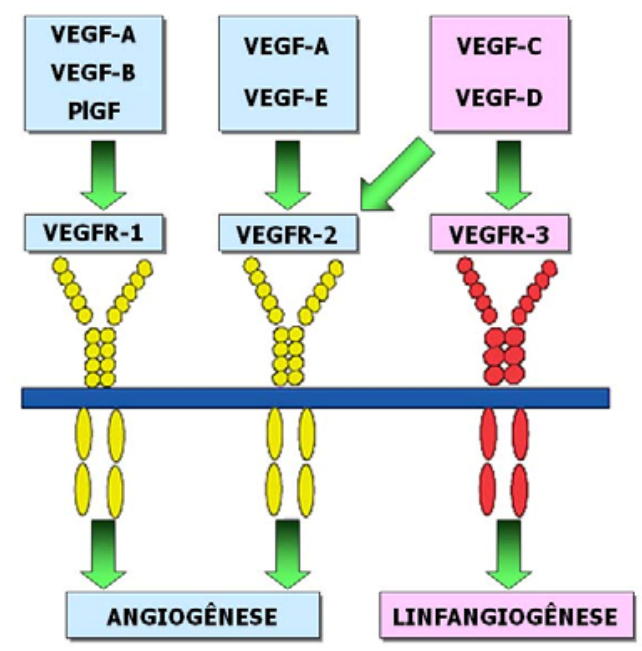

FIGURA 1 - VEGFs conhecidos e seus receptores correspondentes (VEGFRs) (adaptado de AL-RAWI; MANSEL; JIANG ${ }^{3}$, 2005). 
O VEGFR-3, receptor para VEGF-C e VEGF-D, é altamente expresso em angioblastos, veias e vasos linfáticos durante a vasculogênese embrionária, mas torna-se quase restrito ao endotélio linfático nos tecidos adultos normais ${ }^{27,53}$. No trabalho de OKAMOTO et al. ${ }^{43}$, em 2002, os autores correlacionaram à expressão imuno-histoquímica deste receptor em 59 pacientes portadores de carcinomas espinocelulares de língua com estádios clínicos I e II e concluíram que a imunopositividade para VEGFR-3 associada a uma espessura tumoral superior a $4 \mathrm{~mm}$ aumenta particularmente o risco destes pacientes desenvolverem metástase nos linfonodos regionais.

A disseminação metastática dos tumores epiteliais pode ocorrer via sistema sangüíneo ou linfático. A escolha da via de escape principal depende de particularidades da neoplasia maligna, bem como da rede vascular presente ao redor do tumor primário ${ }^{13,49}$. No câncer de mama, por exemplo, as células neoplásicas metastatizam preferencialmente via sistema linfático, devido à extensa rede de microvasos linfáticos da região ${ }^{13,49}$. A chegada de células tumorais aos linfonodos regionais consiste no indicador de prognóstico mais importante para os pacientes com câncer ${ }^{9,23,25,29,42,57}$. Porém, múltiplos passos são necessários para as células tumorais sofrerem metástase do seu sítio primário para os linfonodos regionais. Estes passos incluem o destacamento da célula da neoplasia primária, a invasão dos vasos linfáticos, o transporte através dos mesmos, a retenção nos linfonodos, bem como a sobrevivência e o crescimento tumoral dentro destes ${ }^{19}$.

Portanto, o estudo de fatores de crescimento associados a maior propensão de disseminação neoplásica via vasos linfáticos, como o VEGF-C, tem sido de grande valor na busca de marcadores moleculares que interfiram no prognóstico dos pacientes portadores de tumores sólidos malignos.

\section{1 - EXPRESSÃO DE VEGF-C EM TUMORES SÓLIDOS MALIGNOS}

O VEGF-C tem sido correlacionado a mestástases linfonodais em muitos pacientes portadores de carcinomas $7,9,19,23,28,34,35,36,37,42,54,56,57,60,64,65$, principalmente nos estádios iniciais ${ }^{23,64}$, pois numerosas células neoplásicas podem penetrar nos microvasos linfáticos, preferencialmente aos vasos 
sangüíneos, como resultado da linfangiogênese e dilatação destes vasos promovida pelo VEGF-C ao redor do tumor primário ${ }^{23}$.

Em 1999, TSURUSAKI et al. ${ }^{65}$, estudaram a expressão de VEGF-C em carcinoma de próstata humano e sua correlação com metástase linfonodal, observando que a expressão de RNAm para VEGF-C foi significativamente maior no grupo de comprometimento linfonodal positivo $(\mathrm{pN}+)$. Além disso, o número de vasos linfáticos imunomarcados com o anticorpo anti-VEGFR-3 foi maior no estroma ao redor das células neoplásicas positivas ao VEGF-C. Os autores sugeriram então que a expressão de VEGF-C, pelos carcinomas espinocelulares de próstata, relaciona-se com as metástases linfonodais.

Posteriormente, a expressão do VEGF-A (isoformas: 121, 165, 189, 206), VEGF-B, VEGF-C e VEGF-D em modelos clínicos e experimentais de carcinoma espinocelular de cabeça e pescoço foi determinada e correlacionada com parâmetros clinicopatológicos convencionais com particular referência às metástases linfonodais cervicais por O-CHAROENRAT; RHYS-EVANS; $E_{C C L E S}{ }^{42}$, em 2001. A expressão do RNAm dos VEGFs foi comparada em 14 linhagens de células de carcinomas espinocelulares de cabeça e pescoço (CECCP) com quatro culturas de queratinócitos normais e dez culturas de fibroblastos usando o RT-PCR semi-quantitativo. Os níveis de proteínas foram determinados por Western blot e por ELISA. Os autores então examinaram a expressão de VEGFs nos tecido de 54 pacientes incluindo epitélio normal $(n=32)$, CECs iniciais $(n=23)$, CECs primários avançados $(n=31)$ e metástases linfonodais ( $n=27)$. Níveis aumentados de VEGF-A (suas quatro isoformas) e de VEGF-C foram encontrados nas linhagens de células tumorais em comparação às células normais. A expressão de VEGF-D, entretanto, foi menor nas células dos CECCP. Os resultados mostraram ainda um aumento significativo na expressão das quatro isoformas de VEGF-A e de VEGF-C nos tumores em relação ao epitélio normal. Em contraste, os níveis de VEGF-D foram significantemente menores nos tumores e a expressão de VEGF-B mostrou-se similar em ambos os tecidos normal e maligno. A análise multivariada demonstrou que o modo de invasão infiltrativo e a expressão aumentada de VEGF-A (isoformas 121 e 165) e VEGF-C têm valor preditivo para a presença de metástase cervical. Verificaram também que a alta 
presença de VEGF-A (121 e 165) e de VEGF-C, bem como a baixa presença de VEGF-D foram características comuns nos CECCP. Os autores concluíram com base nestes resultados que os VEGFs -A e -C parecem exercer uma função vital no processo de metástase dos CECCP.

Também BEASLEY et al. ${ }^{9}$, em 2002, quantificaram o VEGF-C por meio da técnica de PCR em tempo real (real-time-PCR) em oito pacientes portadores de carcinomas espinocelulares de cabeça e pescoço (dois de boca, dois de orofaringe, um de laringe e três de hipofaringe). Além disso, os autores utilizaram a técnica imuno-histoquímica, com os anticorpos anti-LYVE-1, antiCD34 e anti-pKi67, em 70 pacientes portadores de carcinomas espinocelulares de cabeça e pescoço, no intuito de correlacionarem a densidade vascular linfática e o índice de proliferação dos espécimes tumorais com as variáveis clínicas e patológicas dos pacientes. As localizações dos 70 carcinomas espinocelulares utilizados na amostra eram a cavidade bucal $(n=31)$, a orofaringe $(n=23)$ e a laringe $(n=16)$. Vinte e seis tumores foram estadiados como T1 e T2, os outros 44 apresentavam estadiamento T3 e T4, sendo que 33 não apresentavam comprometimento linfonodal cervical no momento do exame clínico (N0) e 37 apresentavam linfonodos comprometidos no pescoço $(\mathrm{N}+)$. Todos os pacientes utilizados no estudo submeteram-se à cirurgia como tratamento inicial e alguns receberam radioterapia pós-operatória. Nos carcinomas da orofaginge, uma alta densidade de vasos linfáticos intratumorais foi associada com metástase linfonodal cervical $(p=0,027)$. A quantificação do VEGF-C por PCR em tempo real revelou maiores níveis de RNAm nos tumores analisados do que nos tecidos normais, mas sem uma correlação evidente com os vasos linfáticos intratumorais. Os resultados encontrados reforçaram as evidências de que a proliferação linfática pode ocorrer em cânceres humanos, contribuindo para a ocorrência de metástase linfonodal.

A expressão de VEGF-C e seu receptor VEGFR-3 foi investigada em carcinomas espinocelulares de cabeça e pescoço por RT-PCR semiquantitativo (quatro linhagens de células de CECCP de seis espécimes tumorais) e por imuno-histoquímica (18 pacientes portadores de CECCP) no trabalho de NEUCHRIST; EROVIC; HANDISURYA ${ }^{38}$, em 2003. A expressão da proteína VEGFR-3 foi confirmada por Western blot em quatro linhagens de células de 
CECCP de seis espécimes de CECCP. A análise semiquantitativa de RNAm para VEGF-C mostrou expressão em três das quatro linhagens de células de CECCP dos seis espécimes utilizados. A técnica imuno-histoquímica da estreptavidina-biotina-peroxidase foi realizada em 18 carcinomas espinocelulares de cabeça e pescoço para os seguintes anticorpos primários: policlonal de bode anti-VEGFR3 (R\&D, Minneapolis, MN), policlonal anti-VEGFC de coelho (Zymed, San Francisco, CA), monoclonal anti-CD34-FITC (Serotec, Oxford, UK) e monoclonal anti-Ki 67 (Zymed, San Francisco, CA). Após todas as análises os autores verificaram uma vasta expressão de VEGFC e VEGFR-3 pelas células dos carcinomas espinocelulares de cabeça e pescoço e sugeriram que esta expressão pode contribuir para predizer a ocorrência de metástases linfáticas nos pacientes com estes tumores.

Outros estudos como o de NAKAMURA et al. $^{34}$, em 2003, demonstraram que o VEGF-C exerce uma função crucial nas metástases linfonodais e sugeriram que ele pode ser um fator de prognóstico significativo para a sobrevida das pacientes com câncer de mama. Posteriormente, estes autores verificaram que a expressão de VEGF-C correlaciona-se positivamente com uma maior densidade de vasos linfáticos ao redor das células tumorais, bem como, com a ocorrência de metástases linfonodais sendo, portanto, associada a um pior prognóstico para as pacientes com câncer de mama.

A expressão de VEGF-C e seu receptor VEGFR-3 foi detectada pela técnica imuno-histoquímica da estreptavidina-biotina-peroxidase em 180 pacientes com carcinomas de pulmão por ARINAGA et al. ${ }^{7}$, em 2003. Os pacientes que exibiram marcação positiva para o anticorpo anti-VEGF-C demonstraram significativamente taxas menos favoráveis de sobrevida quando comparados com os pacientes que tinham marcação negativa para o mesmo anticorpo $(p=0,003)$. Todavia, as taxas de sobrevida dos pacientes que apresentavam imunomarcação positiva para o VEGFR-3 também foram significativamente menores quando comparadas com pacientes que apresentaram imunomarcação negativa do mesmo $(p<0,001)$. Pacientes com expressão imuno-histoquímica tanto para o VEGF-C quanto para o VEGFR-3 exibiram um prognóstico desfavorável. Os autores concluíram que a expressão 
de VEGF-C pode ser indicativa de taxas de sobrevida para pacientes com câncer de pulmão.

Os estudos do VEGF-C associados à linfangiogênese nos tumores malignos consistem em um tema insistentemente investigado nos últimos $\operatorname{anos}^{1,2,3,18,45,51,53,55,60,67}$. Tem sido sugerido ${ }^{19}$ que o VEGF-C secretado pelas células neoplásicas, estimula a expressão do seu receptor VEGFR-3 induzindo a dilatação dos vasos linfáticos pré-existentes ao redor do tumor primário, 0 que facilitaria a disseminação da célula maligna e o processo metastático, conforme ilustrado pela Figura 2.

Corroborando com os achados sobre linfangiogênese tumoral SU et al. ${ }^{61}$, em 2006, estudaram a ação do VEGF-C e seu receptor Flt-4, via promoção de linfangiogênese em animais, na ocorrência de metástase de adenocarcinoma de pulmão humano. Os autores evidenciaram que a função do mecanismo molecular envolvido no eixo VEGF-C/FIt-4, revelado por modelos in vitro e in vivo, aumentou a mobilidade e a invasividade das células cancerígenas contribuindo com suas metástases.

Maiores detalhes sobre a linfangiogênese tumoral e a ocorrência de metástases foram descritos nos artigos de revisão publicados por PEPPER et al. $^{45}$, 2003, HE; KARPANEN; ALITALO ${ }^{18}$, 2004, SAHARINEN et al. ${ }^{51}$, 2004, ALRAWI; MANSEL; JIANG ${ }^{3}, 2005$, SCHOPPMANN ${ }^{53}$, 2005, ACHEN; STACKER ${ }^{1}$, 2006, SHAYAN; ACHEN; STACKER ${ }^{55}, 2006$, VAN DER AUWERA et al. ${ }^{67}, 2006$ e SU et al. ${ }^{60}, 2007$. 


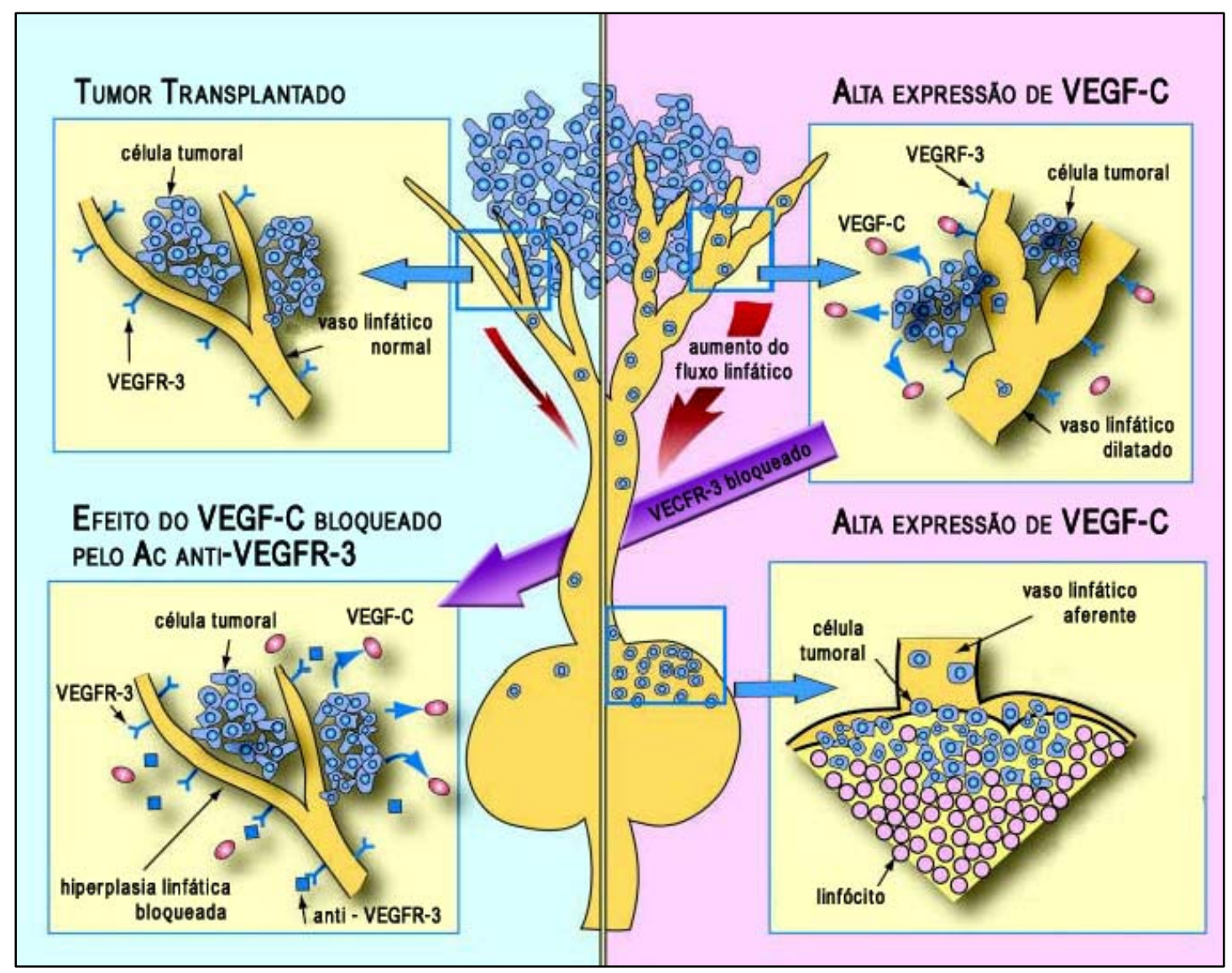

FIGURA 2 - O VEGF-C secretado pelas células tumorais estimula o VEGFR-3 expresso nas células endoteliais linfáticas e assim induz a hiperplasia nos vasos linfáticos peritumorais (em cima à direita). Um aumento da área de superfície linfática aumenta a oportunidade para a entrada da célula tumoral nos vasos linfáticos. O aumento do fluxo linfático também aumenta a disseminação de células tumorais aos linfonodos. Por outro lado, tumores transplantados não induziram uma forte hiperplasia linfática, embora o diâmetro linfático estivesse aumentado em comparação aos tecidos normais (em cima à esquerda). Um aumento do número de células tumorais foi entregue aos linfonodos cervicais dos camundongos portadores de tumores com alta expressão de VEGF-C (embaixo à direita). Chegam mais células neoplásicas aos linfonodos do que as que formarão metástase. As taxas de apoptose e de proliferação das células tumorais não estavam aumentadas nos linfonodos dos tumores com alta expressão de VEGF-C. O anticorpo anti-VEGFR-3 de bloqueio impede a atuação do VEGF-C evitando a hiperplasia dos vasos linfáticos e a disseminação de células tumorais para os linfonodos (abaixo à esquerda). O VEGF-C parece aumentar a ocorrência de metástase linfática pelo aumento da área de superfície dos vasos linfáticos e do fluxo linfático até o momento em que a célula neoplásica entra no vaso linfático (adaptado de HOSHIDA et al. $\left.{ }^{19}, 2006\right)$. 


\section{2 - EXPRESSÃO DE VEGF-C NO CARCINOMA ESPINOCELULAR DE BOCA}

Nos carcinomas espinocelulares de boca, a expressão de VEGF-C pelas células epiteliais malignas também tem sido correlacionada com metástases linfonodais ${ }^{23,28,36,37,54,56,64}$.

KISHIMOTO et al. $^{23}$, em 2003, investigaram a associação da expressão de VEGF-C com metástase linfonodal regional em pacientes portadores de carcinomas espinocelulares de boca, tratados no Departamento de Cirurgia Bucal e Maxilofacial do Hospital Universitário Odontológico de Okayama, Japão, entre os anos de 1985 e 1997. Foram utilizadas 62 biópsias, sendo 38 carcinomas com estádios T1 e T2 e 24 com estádios T3 e T4. Nenhum paciente foi submetido a radioterapia ou quimioterapia pré-operatória. Cortes microscópicos de $4 \mu \mathrm{m}$ de espessura foram obtidos e submetidos à técnica imuno-histoquímica para a detecção dos anticorpos: policlonal antiVEGF-C e monoclonal anti-CD31. A expressão citoplasmática de VEGF-C foi definida como negativa quando $0-25 \%$ das células malignas apresentavam-se imunomarcadas e como positiva quando mais de $25 \%$ das células malignas mostravam-se imunomarcadas. Para a determinação da densidade microvascular o número médio de vasos positivos para o anticorpo anti-CD31 foi obtido em cinco campos microscópicos randomizados com aumento de 200X. Nos estádios T1 e T2 $(n=38)$ a forte expressão de VEGF-C mostrou correlação com as metástases linfonodais $(p<0,001)$, quinze $(88,2 \%)$ dos 17 pacientes com comprometimento histopatológico dos linfonodos regionais $(\mathrm{pN}+)$ apresentaram uma expressão positiva para o VEGF-C e uma porcentagem menor de 28,6\% equivalente a seis dos 21 pacientes sem comprometimento cervical ( $\mathrm{pN}$-) também mostraram uma expressão positiva para o anticorpo avaliado. Entretanto, para os carcinomas espinocelulares em estádios avançados, T3 e T4, não houve correlação significativa entre a expressão de VEGF-C e a ocorrência de metástases em linfonodos regionais. Os espécimes com expressão positiva ao VEGF-C mostraram uma maior densidade microvascular sangüínea do que os espécimes com expressão negativa, embora não houvesse correlação estatística significante entre a expressão de VEGF-C e o aumento da densidade microvascular. A taxa de 
sobrevida específica por câncer foi menor para o grupo com expressão positiva de VEGF-C, entretanto o fator de prognóstico independente para a amostra estudada foi o comprometimento linfonodal regional. Em conclusão, os autores sugeriram que a expressão de VEGF-C em biópsias de carcinomas espinocelulares de boca pode ser usada como um fator preditivo de metástases linfonodais, particularmente nos estadiamentos precoces do CEC de boca, podendo se tornar um importante fator para a seleção do tratamento mais adequado a estes pacientes.

No estudo de SEDIVY et al. ${ }^{54}$, em 2003, 28 pacientes (vinte e dois homens e seis mulheres) portadores de carcinomas espinocelulares de boca e tratados no Departamento de Cirurgia Bucal e Maxilofacial de LKH Salzburg, Áustria, foram estudados. A média de idade dos pacientes foi de 52,93 anos variando de 26 a 76 anos. Todos os pacientes foram submetidos a ressecção cirúrgica e ao esvaziamento cervical supra-homo-hióideo ou radical modificado. Dezessete pacientes receberam radioterapia pós-operatória e um deles recebeu quimioterapia adjuvante. O tempo de seguimento variou de 6 a 222 meses. Espécimes do tumor e da ressecção da margem cirúrgica foram obtidos dos arquivos do Departamento de Patologia (LKH Salzburg, Áustria). O estadiamento e a graduação dos tumores foram feitos de acordo com as classificações da OMS e da UICC respectivamente. A amostra apresentava três carcinomas espinocelulares pT1, treze pT2, três pT3 e nove pT4, além disso, oito pacientes apresentaram comprometimento linfonodal metastático no momento da cirurgia (um paciente pN1, quatro pacientes pN2 e dois pacientes pN3). Quanto à localização vinte tumores localizavam-se no assoalho de boca, cinco no processo alveolar e os outros três na mucosa jugal, na língua e na loja amigdaliana. Os espécimes parafinados foram processados pelas técnicas de rotina e cortes de $3 \mu \mathrm{m}$ de espessura foram obtidos para as técnicas de HE e imuno-histoquímica. O anticorpo de coelho anti-podoplanina foi usado para marcar os vasos linfáticos e o anticorpo monoclonal anti-CD34 para a detecção dos vasos sangüíneos e a determinação da densidade microvascular. A expressão de VEGF-C, verificada pelo anticorpo policlonal de coelho antiVEGF-C, foi obtida quantificando-se a porcentagem de células malignas com imunomarcação positiva em três campos microscópicos (aumento de 400X). A 
porcentagem de células neoplásicas imunomarcadas foi utilizada para a classificação da expressão do anticorpo anti-VEGF-C em: fraca (< 30\%), moderada $(30 \%$ a $60 \%)$ ou forte $(>60 \%)$. Nenhuma diferença foi analisada com relação à intensidade da marcação imuno-histoquímica. A densidade microvascular linfática e a densidade microvascular sangüínea foram determinadas em um pequeno aumento (20X) sendo a área com uma alta densidade vascular (hot spot) localizada e o número de microvasos contados em três campos microscópicos. A expressão de VEGF-C foi significativamente correlacionada com uma elevada densidade de vasos linfáticos, metástases linfonodais e graduação histopatológica. Baseados nesses resultados concluíram que a expressão de VEGF-C nos carcinomas espinocelulares de boca desencadeia a linfangiogênese, e pode resultar num maior risco de metástases em linfonodos cervicais. Sugeriram então, que biópsias imunomarcadas com VEGF-C poderiam auxiliar na adequada indicação de pacientes ao esvaziamento cervical.

As expressões imuno-histoquímicas de furina e de VEGF-C, bem como a densidade microvascular em fragmentos de língua humana contendo epitélio normal, epitélio displásico e carcinoma espinocelular (CEC) foram investigadas por LÓPEZ DE CICCO et al. ${ }^{30}$, em 2004. A família PDGF/VEGF, incluindo o VEGF-C, consiste em um substrato da ação da enzima furinaconvertase. Quarenta e seis pacientes portadores de carcinoma espinocelular de língua foram submetidos à excisão cirúrgica no Centro de Câncer Fox Chase, Filadélfia, EUA. Os espécimes tumorais apresentavam displasia epitelial ( $n=21)$ e/ou carcinoma espinocelular invasivo $(n=44)$, bem como epitélio adjacente à lesão com padrão de normalidade ( $n=46)$. A amostra foi estudada quanto à expressão de furina, a expressão de VEGF-C e a densidade microvascular. Nos 46 espécimes da amostra, embebidos em parafina, a expressão do anticorpo primário anti-furina-convertase foi verificada por meio da técnica imuno-histoquímica da avidina-biotina-peroxidase. De um seleto grupo de 15 espécimes parafinados contendo epitélio normal, lesões precursoras e CEC invasivo, foram obtidos cortes microscópicos e após os procedimentos iniciais de rotina os anticorpos primários utilizados foram 0 policlonal anti-VEGF-C de coelho (Santa Cruz Biotechnology, Santa Cruz, CA, 
EUA) e o monoclonal de camundongo anti-fator-VIII-related antigen (Dako, Carpinteria, CA, EUA). A avaliação imuno-histoquímica semiquantitativa foi baseada na porcentagem de células imunomarcadas e classificada em 0 (nenhuma ou $<5 \%$ das células imunopositivas), I (5-50\% das células imunopositivas) ou II (>50\% das células imunopositivas). Os pesquisadores também analisaram o padrão de furina e VEGF-C por meio de Western blot em três linhagens celulares de CEC com diferentes graus de agressividade. As expressões de furina e de VEGF-C foram notadamente maiores na maioria de lesões cancerizáveis e nos CECs do que nos epitélios normais. Aproximadamente $60 \%$ e $100 \%$ dos epitélios normais mostraram baixas expressões de furina e de VEGF-C, respectivamente. Intensa imuno-marcação de furina e de VEGF-C foram detectadas em $80 \%$ e $100 \%$ de CECs, respectivamente. No presente estudo, os autores mostraram que a expressão de furina e de VEGF-C aumenta simultaneamente conforme a densidade microvascular numa série de lesões pré-invasivas e nos carcinomas espinocelulares de língua. Eles também encontraram um aumento significativo na densidade microvascular quando ambos, displasia e CEC foram comparados ao epitélio normal. Os achados mostraram que há uma forte associação entre a progressão de carcinomas espinocelulares de língua em humanos, a expressão de furina, a expressão de VEGF-C e a neovascularização. Os autores sugeriram então, que a furina pode promover angiogênese associada ao tumor por meio do aumento no processamento de VEGF-C.

Segundo SHINTANI et al. ${ }^{56}$, em 2004, o VEGF-A é conhecido por seu importante papel na angiogênese tumoral, entretanto se outros membros da família VEGF exercem alguma função na angiogênese tumoral e na metástase linfonodal ainda é amplamente desconhecido. Portanto, os autores tiveram por objetivo explorar a função dos membros da família VEGF (em especial, -A, -B, -C e -D) em carcinomas espinocelulares de boca. Eles avaliaram a expressão destes fatores por imuno-histoquímica, RT-PCR e Western blot. Exemplos de 98 CECs de boca foram obtidos de pacientes, sem tratamento prévio, do Departamento de Cirurgia Bucomaxilofacial, Ehime University School of Medicine (Ehime, Japão), entre os anos de 1991 e 2001. 
Quinze pacientes apresentavam estádio clínico I, 29 estádio II, 28 estádio III e 26 estádio IV, de acordo com a classificação $\mathrm{TNM}^{31,58}$. O grau de diferenciação tumoral foi determinado de acordo com o critério proposto pela OMS. Os tecidos previamente fixados em formalina tamponada a $10 \%$ e embebidos em parafina foram cortados com $4 \mu \mathrm{m}$ de espessura. Após desparafinização, hidratação e bloqueio da peroxidase endógena, as lâminas foram incubadas com os seguintes anticorpos primários: anti-CD31 humano monoclonal de rato, anti-VEGF -A, -B, -D policlonal de bode e anti-VEGF-C monoclonal de camundongo. Os tumores foram considerados positivos aos VEGFs quando mais de $80 \%$ das células neoplásicas manifestaram marcação citoplasmática para os anticorpos utilizados. Para determinar a densidade microvascular (MVD), cinco campos microscópicos com alta vascularidade foram selecionados. O número de capilares foi obtido em um microscópio óptico com um aumento de 200X e todos os membros da família VEGF foram expressos em diferentes níveis nos CECs de boca. A análise imuno-histoquímica dos fatores de crescimento e da densidade microvascular revelaram uma correlação entre a expressão de VEGF-A e a de VEGF-B com a angiogênese tumoral. Embora as expressões de VEGF-A e de VEGF-B tenham sido detectadas tanto em linfonodos comprometidos quanto nos não comprometidos pelo CEC, as expressões de VEGF-C e -D foram detectadas mais freqüentemente nos linfonodos comprometidos pelo tumor. Estes achados sugerem uma possível correlação entre o nível da expressão de VEGF-C e/ou VEGF-D e o desenvolvimento de disseminação tumoral linfática. Os autores concluíram que o VEGF-A e o VEGF-B podem induzir a angiogênese tumoral nos carcinomas espinocelulares de boca e que o VEGF-C e o VEGF-D podem induzir a linfangiogênese e parecem ser novos fatores preditivos para metástase linfonodal.

Também em 2004, TANIGAKI et al. ${ }^{64}$ investigaram por imunohistoquímica se as expressões de VEGF-A e de seu receptor Flt-1, bem como de VEGF-C e de seu receptor Flt-4 estão associadas com metástase regional, com metástase à distância e com o prognóstico de pacientes com carcinoma espinocelular de língua. Para o estudo os autores utilizaram espécimes de língua de 73 pacientes (58 homens e 15 mulheres) que foram tratados entre 
1992 e 2002 na University School of Medicine, da cidade de Yokohama, no Japão. Havia 21 pacientes com estágio clínico I, 15 com estágio II, 18 com estágio III e 19 com estágio IV. Quarenta e três pacientes eram N0, 11 N1 e 19 $\mathrm{N} 2$, de acordo com o sistema TNM ${ }^{31,58}$ definido pela UICC e os pacientes com metástase à distância foram excluídos antes da terapia. Todos os casos eram carcinomas espinocelulares que foram identificados histopatologicamente: 47 bem diferenciados, 23 moderadamente diferenciados e 3 pouco diferenciados. Para a técnica imuno-histoquímica, foram utilizados cortes microscópicos de 4 $\mu \mathrm{m}$ de espessura obtidos de espécimes previamente fixados em formalina $(10 \%)$ e incluídos em parafina. Após desparafinização, hidratação e bloqueio da peroxidase endógena foi realizada a recuperação. Os cortes microscópicos foram incubados com os seguintes anticorpos primários: anti-VEGF-A, antiVEGF-C, anti-FIt-1 e anti-Flt-4, para posterior visualização com a reação de diaminobenzina. Os resultados foram categorizados de acordo com o seguinte: a) $0-25 \%$ das células imunopositivas, considerou-se imunomarcação negativa, b) $>25 \%$ das células imunopositivas considerou-se imunomarcação positiva. Após a análise estatística, os resultados demonstraram que a expressão de VEGF-A associou-se com metástase à distância e que a expressão de VEGF-C correlacionou-se com a recorrência loco-regional e à distância. A análise multivariada revelou que as metástases linfonodais e a expressão de VEGF-C foram fatores independentes que influenciaram a taxa de sobrevida global. Em conclusão, os autores sugeriram que esta expressão pode ser um fator preditivo para a recorrência em linfonodos regionais e para o prognóstico dos pacientes com carcinoma espinocelular de língua. Entretanto, os autores reforçaram que a utilidade terapêutica da expressão do VEGF-C pelas células tumorais precisa ser melhor investigada.

Em 2005, usando 36 espécimes de carcinoma espinocelular de língua, induzidos por DMBA em hamster, e cinco animais normais como controle, NAKAYA et al. ${ }^{36}$ verificaram a densidade microvascular sangüínea e linfática, bem como a expressão imuno-histoquímica de VEGF-C. Quanto ao padrão de invasão tumoral os autores classificaram os tumores em graus: 1, 2, 3, 4C e 4D, do padrão menos agressivo para o mais agressivo. A imunomarcação do anticorpo anti-VEGF-C foi avaliada de acordo com a 
quantidade de células imunopositivas e a expressão nos espécimes foi classificada como baixa, moderada ou alta. A expressão de VEGF-C foi detectada em abundância no citoplasma das células malignas e em menor intensidade nas células endoteliais, entretanto não foi visualizada expressão imuno-histoquímica de VEGF-C no epitélio normal. Nos tumores menos invasivos a expressão de VEGF-C variou de baixa a moderada, enquanto numerosas células expressaram VEGF-C nos carcinomas espinocelulares mais invasivos. A microdensidade vascular sangüínea diminuiu com o aumento da invasividade tumoral, assim como a microdensidade vascular linfática para os graus 1, 2 e 3 . Os autores não encontraram correlação entre a microdensidade linfática e a expressão de VEGF-C $(p>0,05)$.

O estudo de $\mathrm{LI}$ et al. $^{28}$, em 2006, investigou a expressão do anticorpo anti-VEGF-C e de seu receptor Flt-4 (VEGFR-3) em 99 espécimes de carcinomas espinocelulares de língua e em 17 espécimes de lesões benignas de língua, por meio da técnica imuno-histoquímica da estreptavidina-biotinaperoxidase. As correlações da expressão de VEGF-C e Flt-4 com os parâmetros clínicos e o prognóstico dos pacientes foram analisadas e os autores encontraram que as taxas de imunomarcação positiva tanto para o VEGF-C quanto para o Flt-4 foram significativamente maiores nos tumores de língua do que nas lesões benignas. Além disso, a expressão imunopositiva de VEGF-C foi significativamente maior nos pacientes com metástase linfonodal cervical do que nos pacientes sem comprometimento do pescoço $(43,75 \%$ vs $20 \%, p<0,05)$ e significativamente menor nos estádios clínicos I e II do que nos estádios III e IV (TNM/UICC $\left.{ }^{31,58}\right)$ para os tumores malignos $(18,52 \%$ vs $41,67 \%$, $p<0,05)$. As taxas cumulativas de sobrevida dos pacientes com marcação imunopositiva de VEGF-C e de FIt-4, para cinco anos, foram significativamente menores do que para os pacientes com expressão negativa de ambos os anticorpos estudados. Portanto, os autores concluíram que os pacientes com alta expressão imuno-histoquímica de VEGF-C e Flt-4 apresentam um pior prognóstico.

Ainda em 2006, no intuito em definir o padrão de expressão dos fatores de crescimento endotelial vascular $-A$ e $-C$ em carcinomas espinocelulares de boca e sua correlação com variáveis clínico-patológicas, 
NAKAZATO et al. ${ }^{37}$ determinaram os níveis de expressão destes VEGFs em linhagens de células de carcinoma espinocelular de boca (HSC-2, HSC-3, HSC-4 e OSC-19) pelo método quantitativo de RT-PCR. Os autores examinaram a relação do VEGF-A e do VEGF-C com metástase linfonodal regional, metástase à distância e densidade microvascular intratumoral dos tumores transplantados para camundongos. Os autores verificaram que as linhagens de células HSC-2 e OSC-19 expressaram níveis significativamente maiores de VEGF-A e $-C$, correlacionando-se com presença de metástase linfonodal regional e alta densidade microvascular. Como conclusão os autores sugeriram que o VEGF-C pode ser um fator preditivo para metástase linfonodal.

Num estudo atual, publicado em 2007, WARBURTON e colaboradores $^{69}$ investigaram a expressão imuno-histoquímica de VEGF-C, VEGF-D e VEGFR-3 em carcinomas espinocelulares de língua e assoalho bucal de pacientes, com estádios clínicos iniciais I e II, submetidos à remoção cirúrgica do tumor primário como único tratamento inicial, na Faculdade de Odontologia da Universidade de Maryland, Baltimore, EUA. Os vinte e nove pacientes selecionados para a amostra não foram submetidos ao esvaziamento cervical eletivo ou à radioterapia. Cortes microscópicos de $5 \mu \mathrm{m}$ de espessura foram obtidos dos espécimes parafinados e após desparafinização e hidratação foram submetidos à técnica imuno-histoquímica da estreptavidina-biotinaperoxidase. Os anticorpos primários utilizados foram o anti-VEGF-C (Santa Cruz Biotechnology, Santa Cruz, CA; sc-1881), o anti-VEGFR-3 (Santa Cruz Biotechnology; sc-321) e o anti-VEGF-D (Santa Cruz Biotechnology; sc-7603). A imunomarcação foi classificada de acordo com a porcentagem de células com expressão positiva para os anticorpos analisados de acordo com os escores: 0 (0-5\% das células positivas), 1 (6-25\% das células positivas), 2 (26$50 \%$ das células positivas) ou 3 (51-100\% das células positivas). A intensidade da imunomarcação foi graduada como fraca, moderada ou forte. Nenhum dos parâmetros clínicos analisados mostrou correlação estatisticamente significativa com a ocorrência de metástase linfonodal regional. A maioria dos pacientes que apresentaram metástase regional cervical $(87,5 \%)$ mostraram alguma expressão de VEGF-C e esta porcentagem foi maior do que a 
encontrada nos pacientes que não desenvolveram metástase linfonodal no pescoço (57,9\%). Embora nenhum dos parâmetros estudados pelos autores tenha sido exclusivamente associado com metástase linfonodal, eles sugerem que a espessura, o pleomorfismo nuclear, o padrão de invasão, a queratinização, a expressão de VEGFR-3 e a expressão de VEGF-C em conjunto podem predizer o envolvimento linfonodal nos estádios iniciais do carcinoma espinocelular de boca.

De acordo com esta revisão de literatura, o VEGF-C parece constituir uma molécula de ligação entre a linfangiogênese e as metástases regionais em carcinomas espinocelulares de diferentes sítios anatômicos, incluindo aqueles localizados na boca. Entretanto, os autores reforçam que são necessárias outras investigações visando contribuir com a utilização deste fator de crescimento como adjuvante na estratégia terapêutica para a adequada indicação dos pacientes ao esvaziamento cervical. Principalmente nos estádios clínicos iniciais (l e II) do carcinoma espinocelular de boca, predizer a ocorrência de metátase linfonodal é de fundamental importância para aumentar as taxas de sobrevida dos pacientes com este tipo de neoplasia. 
3 - Proposição 


\section{3 - PROPOSIÇÃO}

O presente estudo teve por objetivos:

1) verificar, a partir da análise microscópica de carcinomas espinocelulares de boca, com estadiamento clínico I e II, localizados na língua e no assoalho de boca:

$\Rightarrow$ a expressão imuno-histoquímica do fator de crescimento endotelial vascular do tipo C (VEGF-C) pelas células malignas, nas regiões do front de invasão tumoral;

$\Rightarrow$ a correlação da expressão de VEGF-C na ocorrência de metástases em linfonodos cervicais, principalmente as ocultas, e no prognóstico dos pacientes.

2) contribuir para a identificação de fatores prognósticos em pacientes com carcinomas espinocelulares de língua e de assoalho bucal, com estadiamento clínico I e II, que poderiam reforçar a adequada indicação ao esvaziamento cervical. 
4 - Casuística e Métodos 


\section{4 - CASUÍSTICA E MÉTODOS}

\section{1 - POPULAÇÃO DE ESTUDO}

A população de estudo foi constituída por pacientes portadores de carcinoma espinocelular de boca, submetidos a tratamento no Departamento de Cirurgia de Cabeça e Pescoço e Otorrinolaringologia, do Centro de Tratamento e Pesquisa do Hospital do Câncer A. C. Camargo, São Paulo - SP, Brasil, no período de 1968 a 2001. Parte desta amostra foi previamente estudada por AMARAL et al. ${ }^{5}$, em 2004.

Os pacientes foram selecionados de acordo com os seguintes critérios de inclusão:

1) pacientes com carcinoma espinocelular, estadiamento clínico I ou II, localizados na língua ou no assoalho bucal, com diagnóstico confirmado por exame histopatológico;

2) pacientes submetidos à cirurgia como tratamento inicial;

3) prontuário com seguimento clínico completo;

4) fragmento de tumor suficiente para análise microscópica;

5) disponibilidade dos respectivos blocos de parafina.

Os critérios de exclusão utilizados foram:

1) presença de outros tumores primários simultâneos;

2) presença de metástase à distância no momento da admissão no hospital;

3) contra-indicação para a cirurgia (pacientes considerados inoperáveis);

4) pacientes submetidos à quimioterapia;

5) pacientes que recusaram o tratamento. 


\section{2 - REGISTRO DOS DADOS CLÍNICOS}

As informações clínicas dos pacientes e as informações da peça cirúrgica inicial foram obtidas por meio de consulta aos respectivos prontuários arquivados no Serviço de Arquivo Médico (SAME) do Hospital do Câncer A. C. Camargo e registradas em formulário próprio, para coleta de dados (APÊNDICE A). Estes registros incluíram a identificação e os dados demográficos dos pacientes, informações relativas à história clínica, exame loco-regional, cirurgia, radioterapia pós-operatória, informações da peça cirúrgica inicial e evolução do paciente, conforme os itens do formulário para coleta de dados. No caso dos pacientes vivos, a evolução clínica foi atualizada até novembro de 2006.

\section{3 - VARIÁVEIS DE ESTUDO}

As variáveis analisadas neste estudo referem-se aos dados demográficos relativos aos pacientes como a idade, o gênero (masculino ou feminino) e a raça (branca ou não branca).

Quanto à história clínica dos pacientes, pesquisou-se o tempo de história (em meses); o tabagismo (não fumante ou fumante) e o etilismo (não etilista ou etilista).

No exame locorregional, a localização do tumor primário foi registrada como sendo de 1-língua ou 2-assoalho de boca. As lesões foram descritas quanto a: extensão do tumor para outros sítios anatômicos; relação com a linha média (compromete ou não compromete); tipo da lesão (1-úlcerovegetante, 2-úlcero-infiltrativa ou 3-outra) e diâmetro aproximado da lesão (em centímetros).

A classificação clínica adotada pelo Centro de Tratamento e Pesquisa do Hospital do Câncer A. C. Camargo segue o sistema TNM/UICC ${ }^{31,58} \mathrm{e}$, portanto, os pacientes do estudo foram classificados pelo estádio clínico em I (T1NOMO) ou II (T2NOMO).

Quanto ao tratamento, registrou-se a data da cirurgia, a realização ou não de esvaziamento cervical (ipisilateral ou ipisilateral e contralateral 
simultâneos), a data da alta hospitalar, bem como os dados referentes à radioterapia pós-operatória, se foi realizada ou não e as datas de início de término do tratamento radioterápico nos pacientes em que se fez necessário.

O diagnóstico do tumor primário, referente ao laudo anatomopatológico (CEC I; CEC II; CEC III ou CEC SOE), serviu de base para o início da análise microscópica da peça cirúrgica.

A queratinização, o pleomorfismo nuclear, o número de mitoses, o padrão de invasão tumoral e o infiltrado inflamatório foram graduados de 1 a 4 , de acordo com o índice de graduação da malignidade de BRYNE et al. ${ }^{11}$ (Tabela 2).

A embolização vascular angiolinfática, a infiltração perineural, a infiltração muscular e a infiltração de glândulas salivares foram classificadas como ausentes ou presentes.

Informações sobre as margens cirúrgicas (0-livres; 1-presentes; 2comprometidas; 9-ignorado) e o número de linfonodos comprometidos e dissecados foram obtidos do laudo anatomopatológico da peça cirúrgica inicial. O comprometimento linfonodal cervical histopatológico $(\mathrm{pN})$ foi registrado como negativo ou positivo.

Quanto à evolução dos pacientes, registrou-se a ocorrência ou não de recidiva local, de metástase regional, de metástase à distância e de segundo tumor primário.

Com o objetivo de caracterização da amostra, registraram-se também a data da primeira recidiva, os locais de recidiva (0-não teve; 1-local; 2-pescoço ipsilateral; 3-pescoço contralateral; 4-pulmão; 5-osso; 6-fígado; 7outra à distância ou 8-recidiva em local ignorado), assim como a data do diagnóstico do segundo tumor primário e o local do segundo tumor primário.

A data e a situação do paciente na última informação objetiva de seguimento foram registradas. Para a variável situação o registro foi feito da seguinte forma: 1-vivo e sem evidência da doença (000); 2-vivo com câncer; 3morte por intercorrência cirúrgica $(\mathrm{MOCl})$; 4-morte decorrente do tumor primário (MOCA); 5-morte sem evidência de recidiva do tumor primário (MOASS) e 6perdido de vista (foram considerados perdidos de vista os pacientes com 
menos de cinco anos de seguimento e que deixaram de retornar por um período igual ao dobro pré-estabelecido). Pacientes assintomáticos que foram perdidos de vista, após cinco anos de seguimento, foram classificados como vivos e livres de doença (000).

\section{4 - ANÁLISE MICROSCÓPICA}

\subsection{1 - Graduação da Malignidade Tumoral}

A graduação da malignidade tumoral foi realizada utilizando-se 0 índice histopatológicos de malignidade proposto por BRYNE et al. ${ }^{11}$, 1989, que se baseia na análise de características morfológicas apresentadas pelas células na região do front de invasão tumoral. Consideramos como front de invasão tumoral, a porção mais invasiva visualizada no corte microscópico analisado.

Para a análise microscópica, a área do front de invasão tumoral de cada espécime foi percorrida e analisada por três examinadores (S.E.S.F, D.T.O e G.L.), sem o conhecimento prévio dos dados clínicos dos pacientes, utilizando-se um microscópio óptico binocular (Axioskop 2 Plus, ZEISS), contendo uma objetiva de 40X. Cortes microscópicos de $3 \mu \mathrm{m}$ de espessura foram obtidos a partir das peças cirúrgicas do tumor primário, que estavam arquivadas no Departamento de Anatomia Patológica do Hospital do Câncer A. C. Camargo. Os cortes foram corados pela técnica da Hematoxilina-Eosina (H.E.) e, posteriormente, analisados quanto à graduação da malignidade nas áreas mais invasivas, de acordo com o escore de malignidade de BRYNE et al. $^{11}$ (1989), apresentado na Tabela 2.

Para cada carcinoma espinocelular de boca o componente individual do sistema de graduação foi analisado e, posteriormente, somado em um escore final de malignidade, podendo variar de 5 a 20 pontos. Os espécimes tumorais foram então classificados como pouco agressivos (escore final $\leq 12$ pontos) ou muito agressivos (escore final $>12$ pontos). 
TABELA 2 - Graduação de malignidade do front de invasão tumoral de BRYNE et al. ${ }^{11}$.

\begin{tabular}{|c|c|c|c|c|}
\hline \multirow{2}{*}{$\begin{array}{l}\text { CARACTERÍSTICAS } \\
\text { MORFOLÓGICAS }\end{array}$} & \multicolumn{4}{|c|}{ ESCORES DE MALIGNIDADE } \\
\hline & 1 & 2 & 3 & 4 \\
\hline $\begin{array}{l}\text { Grau de } \\
\text { queratinização }\end{array}$ & $\begin{array}{c}\text { Intensa } \\
\text { (>50\% das } \\
\text { células) }\end{array}$ & $\begin{array}{c}\text { Moderada } \\
(20-50 \% \\
\text { das células })\end{array}$ & $\begin{array}{c}\text { Baixa } \\
\text { (5-20\% das } \\
\text { células) }\end{array}$ & $\begin{array}{c}\text { Ausente } \\
\text { (0-5\% das } \\
\text { células) }\end{array}$ \\
\hline $\begin{array}{l}\text { Polimorfismo } \\
\text { nuclear }\end{array}$ & $\begin{array}{c}\text { Discreto } \\
\text { (>75\% das } \\
\text { células } \\
\text { maduras) }\end{array}$ & $\begin{array}{c}\text { Moderado } \\
\text { (50-75\% } \\
\text { das células } \\
\text { maduras) }\end{array}$ & $\begin{array}{c}\text { Intenso } \\
(25-50 \% \\
\text { das células } \\
\text { maduras) }\end{array}$ & $\begin{array}{c}\text { Extremo } \\
(0-25 \% \text { das } \\
\text { células } \\
\text { maduras })\end{array}$ \\
\hline Número de mitoses & 0 a 1 & 2 a 3 & 4 a 5 & $>5$ \\
\hline Padrão de invasão & $\begin{array}{c}\text { Compressivo } \\
\text { e com } \\
\text { bordas bem } \\
\text { definidas }\end{array}$ & $\begin{array}{l}\text { Cordões } \\
\text { sólidos e } \\
\text { grossos de } \\
\text { células } \\
\text { tumorais }\end{array}$ & $\begin{array}{l}\text { Cordões } \\
\text { finos de } \\
\text { células } \\
\text { tumorais }\end{array}$ & $\begin{array}{c}\text { Células } \\
\text { tumorais } \\
\text { isoladas ou } \\
\text { dissociadas } \\
\text { em } \\
\text { pequenos } \\
\text { grupos }\end{array}$ \\
\hline $\begin{array}{l}\text { Resposta do } \\
\text { hospedeiro }\end{array}$ & Intensa & Moderada & Leve & Ausente \\
\hline
\end{tabular}

\subsection{2 - Técnica Imuno-Histoquímica}

A marcação imuno-histoquímica dos espécimes tumorais seguiu a técnica da estreptavidina-biotina-peroxidase, previamente padronizada no plano piloto, de acordo com o protocolo de reações utilizado no Setor de Imuno-histoquímica do Centro de Tratamento e Pesquisa da Fundação Antônio Prudente, São Paulo - SP e conforme os passos descritos a seguir:

$\Rightarrow$ Obtenção de cortes microscópicos de $3 \mu \mathrm{m}$ de espessura dos carcinomas espinocelulares fixados em formalina e incluídos em parafina;

$\Rightarrow$ Os cortes foram colocados em lâminas de vidro do tipo silanizadas (25 x $75 \times 1 \mathrm{~mm}$, Superfrost Plus, EASYPATH) para desparafinização e hidratação: estufa a $60^{\circ} \mathrm{C}$ por 24 horas; xilol a $60^{\circ} \mathrm{C}$ por 20 minutos; xilol a temperatura ambiente por 20 minutos; etanol a $100 \%$ 
por 30 segundos; etanol a $95 \%$ por 30 segundos; etanol a $70 \%$ por 30 segundos;

$\Rightarrow$ Lavagem das lâminas em água corrente e destilada;

$\Rightarrow$ A recuperação antigênica foi realizada por meio da incubação dos espécimes em solução de tampão citrato a $10 \mathrm{mM}$ e $\mathrm{pH} 6,0$. A solução foi fervida em panela de pressão (Eterna, NIGRO) destampada. Posteriormente, as lâminas foram mergulhadas e a panela lacrada com a válvula de segurança aberta. Após a saída do vapor saturado, a válvula de segurança foi abaixada e aguardou-se a pressurização total. Quatro minutos foram contados após este sinal;

$\Rightarrow$ Resfriamento da panela ainda fechada sob água corrente por 10 minutos. A seguir, a panela foi destampada e deixada por 10 minutos à temperatura ambiente;

$\Rightarrow$ Lavagem das lâminas em água corrente e destilada;

$\Rightarrow \mathrm{O}$ bloqueio da peroxidase endógena foi realizado com $\mathrm{H}_{2} \mathrm{O}_{2}$ a $3 \%$ (água oxigenada a 10 volumes), com 4 trocas de 5 minutos cada;

$\Rightarrow$ Lavagem em água corrente, água destilada e solução salina tamponada com fosfatos (PBS $=$ Phosphate Buffered Saline) a $10 \mathrm{mM}$ e $\mathrm{pH} 7,4$, por 5 minutos;

$\Rightarrow$ Realizou-se então a incubação com o anticorpo primário policlonal de bode anti-VEGF-C (C-20) (Santa Cruz Biotechnology, sc-1881, Santa Cruz, CA, EUA), no título pré-estabelecido de 1:100, diluído em tampão PBS contendo albumina bovina (BSA) a 1\% (Sigma, A9647, EUA) e azida sódica $\left(\mathrm{NaN}_{3}\right)$ a $0,1 \%$, por 18 horas a $4^{\circ} \mathrm{C} \mathrm{em}$ câmara úmida;

$\Rightarrow$ Lavagem das lâminas em tampão PBS com 3 trocas de 3 minutos cada;

$\Rightarrow$ Incubação com o anticorpo secundário biotinilado (Biotinylated antigoat Ig (HTL) made in rabbit, Vector BA-5000, Burlingame, CA, 
EUA), no título pré-estabelecido de 1:500, diluído em PBS, por 30 minutos a $37^{\circ} \mathrm{C}$;

$\Rightarrow$ Lavagem das lâminas em tampão PBS com 3 trocas de 3 minutos cada;

$\Rightarrow$ Procedeu-se então a incubação com o complexo - reagente $A$ (streptavidin) e reagente B (biotinylated peroxydase), ambos do kit StreptABCComplex/HRP Duet (mouse/rabbit) (Dako A/S, K0492, Dinamarca), no título pré-estabelecido de 1:200, diluído em PBS, por 30 minutos a $37^{\circ} \mathrm{C}$;

$\Rightarrow$ Lavagem das lâminas em tampão PBS com 3 trocas de 3 minutos cada;

$\Rightarrow$ O produto final da reação antígeno-anticorpo foi visualizado por meio da incubação das lâminas em solução substrato: 3,3' diaminobenzidine tetrahydrochloride (DAB) a 60 mg\% (Sigma, D5637, EUA); $1 \mathrm{~mL}$ de Dimetilsulfóxido (DMSO); $1 \mathrm{~mL}$ de $\mathrm{H}_{2} \mathrm{O}_{2}$ a $6 \%$ (água oxigenada a 20 volumes); $100 \mathrm{~mL}$ de PBS; por 5 minutos a $37^{\circ} \mathrm{C}$, ao abrigo da luz;

$\Rightarrow$ Visualização ao microscópio óptico, nas lâminas controles, do desenvolvimento de precipitado castanho dourado, como produto final da reação;

$\Rightarrow$ Lavagem em água corrente e água destilada por 3 minutos;

$\Rightarrow$ Os cortes foram contracorados com Hematoxilina de Harris por 1 minuto;

$\Rightarrow$ Lavagem em água corrente e destilada;

$\Rightarrow$ Imersão em água amoniacal (solução de hidróxido de amônio a $0,5 \%)$ por duas vezes;

$\Rightarrow$ Lavagem em água corrente e destilada;

$\Rightarrow$ Desidratação: etanol a $80 \%$ por 30 segundos; etanol a $95 \%$ por 30 segundos; etanol a $100 \%$ duas vezes por 30 segundos cada; xilol quatro vezes por 30 segundos cada; 
$\Rightarrow$ Montagem com a utilização de resina adesiva Entellan Neu (Merck, 1.07961, Alemanha) e lamínulas.

Um controle positivo e um controle negativo foram incluídos em cada série de colorações imuno-histoquímicas. Utilizou-se como controle positivo um espécime de placenta humana e como controle negativo um corte do mesmo tecido com a omissão do anticorpo primário. A presença de mucosa bucal com padrão de normalidade nas margens cirúrgicas dos carcinomas espinocelulares foi utilizada como controle imuno-histoquímico interno.

\subsection{3 - Avaliação Imuno-Histoquímica}

A avaliação da expressão imuno-histoquímica do anticorpo antiVEGF-C, nos carcinomas espinocelulares de língua e assoalho de boca, foi realizada por meio de um sistema computadorizado de captura de imagens na região do front de invasão tumoral. Aproximadamente 30 campos microscópicos para cada espécime tumoral (87 CECs) foram adquiridos a partir de uma câmera digital de alta resolução (Axiocam MRc, ZEISS) acoplada a um microscópio óptico binocular (Axioskop 2 Plus, ZEISS) contendo uma objetiva de 40X. A câmera apresentava-se conectada a um microcomputador (Pentium IV, INTEL) contendo um programa de aquisição e análise de imagens (Axiovision 4.5, ZEISS). Cada campo microscópico capturado pelo programa correspondia a uma área de 93.992,05 $\mu^{2}{ }^{2}$. A área percorrida na porção mais invasiva de cada espécime tumoral está discriminada no APÊNDICE B.

O número de campos microscópicos por carcinoma espinocelular variou de 11 a 35 e estes foram obtidos sequencialmente na região do front de invasão tumoral, tomando-se o cuidado de não deixar nenhuma célula repetida por campo.

Cada campo microscópico capturado foi previamente padronizado no programa para microcomputador Axiovision 4.5 (ZEISS) a fim de evitar diferenças na intensidade da expressão do anticorpo anti-VEGF-C. Inicialmente, para cada lâmina a ser utilizada, procedeu-se o ajuste através dos seguintes procedimentos: 
$\Rightarrow$ Antes do posicionamento da lâmina, na janela de visualização (tecla Live ativada), realizou-se a padronização do fundo branco através da tecla White balance;

$\Rightarrow \mathrm{Na}$ paleta General, procedeu-se a melhor distribuição de sombras com a tecla Shading Correction;

$\Rightarrow$ Posteriormente, a lâmina foi posicionada no microscópio e o front de invasão tumoral localizado com as objetivas de 2,5X (FIGURA 3A), 5X e 10X, respectivamente.

Os procedimentos a seguir foram realizados para cada campo microscópico, sem a necessidade de remoção da lâmina:

$\Rightarrow$ Com a objetiva de 40X posicionada, na paleta Adjust, a tecla Measure foi utilizada para determinar o tempo de exposição (em milésimos de segundo), de acordo com a intensidade de luz emitida pelo microscópio óptico;

$\Rightarrow$ A imagem visualizada apresentava-se com um aumento original de 252X. Este valor foi obtido multiplicando-se o aumento da objetiva (40X), pelo aumento da ocular (10X) e pelo aumento do adaptador $(0,63 X)$ que acopla o microscópio à câmera;

$\Rightarrow$ A fim de padronizar a intensidade de luz a tecla OverExp foi ativada. Quando esta tecla está ativada, áreas vermelhas surgem onde a intensidade de luz está muito alta, ou seja, a imagem encontra-se "estourada". Esta intensidade pode ser controlada de duas formas, reduzindo-se o tempo de exposição ou diminuindo-se a emissão de luz pelo microscópio. Porém, a fim de tornar o ajuste da imagem o mais objetivo possível, o tempo de exposição foi considerado ideal quando pequenos pontos vermelhos eram visualizados nas áreas claras da imagem;

$\Rightarrow$ Na paleta Adjust, a tecla Interactive foi acionada para possibilitar a identificação de um ponto branco da imagem, padronizando o branco (ao olho humano) e juntamente o ajuste automático de cores pelo programa; 
$\Rightarrow$ O último ajuste realizado foi o foco, através da tecla Restart focus bar, que é visualizada na janela aberta sobre a figura após um clique no botão direito do mouse. Esta tecla facilita a padronização do foco independentemente de divergências do olho humano;

$\Rightarrow$ Após todo o ajuste da imagem, o campo microscópico foi capturado pela tecla Snap (FIGURA 3B) e salvado em arquivo próprio com a extensão "zvi”. Esta extensão é própria do programa Axiovision 4.5 (ZEISS) e possibilita alterações posteriores na imagem, bem como, por exemplo, a realização de contagens e medições;

$\Rightarrow$ Após a aquisição, a imagem foi visualizada em toda tela do monitor e então a expressão de VEGF-C pelas células neoplásicas pôde ser analisada.

Para a aquisição dos campos microscópicos realizou-se uma "varredura" seqüencial do front de invasão tumoral, tomando-se o cuidado de não deixar nenhuma célula repetida por campo. 

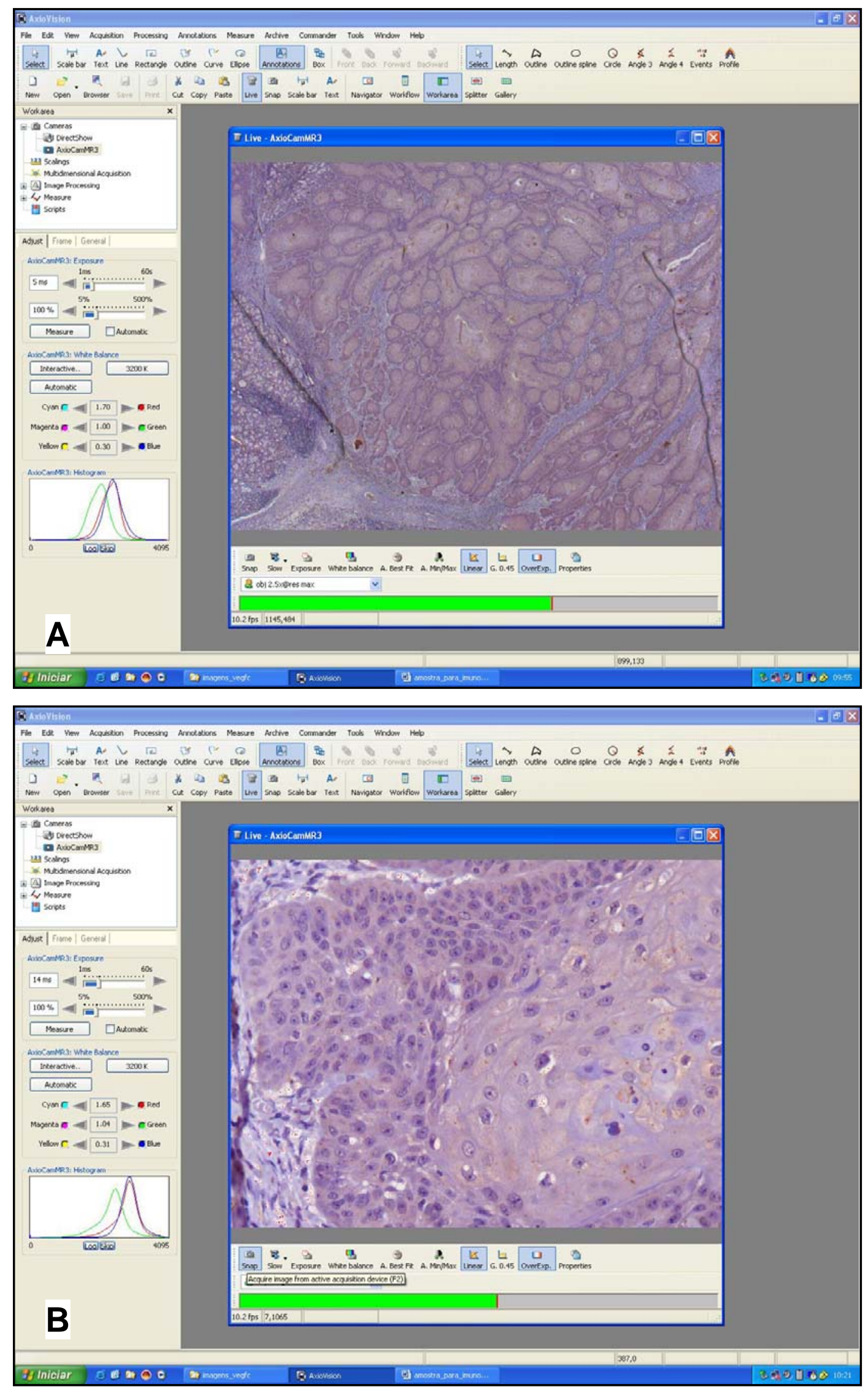

FIGURA 3 - Localização do front de invasão tumoral com a objetiva de 2,5X em A e aquisição da imagem com a tecla Snap em B no programa Axiovision 4.5 (ZEISS). 
Por se tratar de um anticorpo citoplasmático, a expressão do VEGFC pelas células epiteliais malignas, foi avaliada por um método semiquantitativo de escores, baseado na soma da proporção e da intensidade das células tumorais com imunomarcação positiva, conforme previamente descrito por SOINI et al. ${ }^{59}$, porém com modificações na avaliação dos escores finais.

Para cada campo microscópico adquirido a porcentagem de células com imunomarcação positiva foi avaliada e classificada em um dos cinco escores abaixo:

0 = ausência de células tumorais imunopositivas

1 = menos de $25 \%$ de células tumorais imunopositivas

$2=25 \%$ a $50 \%$ de células tumorais imunopositivas

$3=51 \%$ a $75 \%$ de células tumorais imunopositivas

$4=$ mais de $75 \%$ de células tumorais imunopositivas

Posteriormente a intensidade da imunomarcação citoplasmática foi avaliada e classificada em um dos cinco escores abaixo:

0 = ausência de imunomarcação

1 = imunomarcação fraca

2 = imunomarcação moderada

3 = imunomarcação forte

4 = imunomarcação intensa

- Por fim, a soma dos escores, baseada na extensão e na intensidade, foi classificada em três grupos:

0 (escore 0$)$ = ausência de imunomarcação

1 (escores de 1 a 5) = imunomarcação fraca

$2($ escores 6 a 8$)=$ imunomarcação forte 


\section{5 - ANÁLISE ESTATÍSTICA}

As análises estatísticas foram realizadas utilizando-se o programa estatístico para microcomputador SPSS for Windows versão 10.0 (SPSS Inc., Chicago, IL, EUA).

Para a verificação das médias da idade e do tempo de história clínica utilizou-se o teste $t$ de Student.

A associação da expressão imuno-histoquímica do anticorpo antiVEGF-C com as variáveis demográficas, clínicas e microscópicas foi avaliada pelo teste qui-quadrado ou o teste exato de Fisher, com um nível de significância de $5 \%(\rho \leq 0,05)$.

Para a análise da sobrevida global utilizou-se o tempo de seguimento, em meses, entre a data da cirurgia do tumor primário e o óbito do paciente, independente da causa da morte, ou a data da última informação objetiva de seguimento.

Quanto à sobrevida livre de doença considerou-se para sua análise o tempo em meses transcorrido entre a data da remoção cirúrgica do tumor primário e o aparecimento de recidiva tumoral (local, regional ou à distância) ou até a data da última informação objetiva registrada no prontuário médico.

O tempo decorrido, em meses, entre a cirurgia do tumor primário e o óbito em decorrência específica deste tumor foi utilizado para a análise da sobrevida específica por câncer. Para os casos censurados considerou-se a data da última informação objetiva de seguimento.

Para as análises das sobrevidas global, livre de doença e específica foram considerados "não censurados" os pacientes que não apresentaram um evento de interesse (óbito para a sobrevida global, recorrência do tumor primário para a sobrevida livre de doença e óbito pelo tumor primário para a sobrevida específica por câncer). Os casos considerados "censurados" foram aqueles em que até a data da última informação objetiva de seguimento não ocorreu nenhum evento de interesse.

As análises das sobrevidas global, livre de doença e específica por câncer foram feitas pelo estimador produto-limite de Kaplan-Meier. A 
comparação entre as curvas de sobrevida foi realizada pelo teste log-rank, com o nível de significância igual a 5\%.

\section{6 - AQUISIÇÃO DAS FOTOMICROGRAFIAS}

As fotomicrografias apresentadas neste trabalho foram obtidas por meio do mesmo sistema de aquisição e análise de imagens (Axiovision 4.5, ZEISS) utilizado para a avaliação imuno-histoquímica.

\section{7 - COMISSÃO DE ÉTICA EM PESQUISA (CEP)}

Esta pesquisa foi aprovada pela Comissão de Ética em Pesquisa (CEP) do Centro de Tratamento e Pesquisa do Hospital do Câncer A. C. Camargo, em reunião de 29 de novembro de 2005, sob o n746/05 (ANEXO A). 


\section{5 - Resultados}




\section{5 - RESULTADOS}

\section{1 - CASUÍSTICA}

Após o levantamento dos pacientes portadores de carcinoma espinocelular de boca, submetidos a tratamento junto ao Departamento de Cirurgia de Cabeça e Pescoço e Otorrinolaringologia do Centro de Tratamento e Pesquisa do Hospital do Câncer A. C. Camargo, São Paulo - SP, Brasil, no período de 1968 a 2001, foram aplicados os critérios de inclusão do presente estudo e selecionados 87 pacientes com carcinoma espinocelular de língua e assoalho de boca, estádios clínicos I e II, para a realização da pesquisa.

\section{2 - CARACTERIZAÇÃO DEMOGRÁFICA E CLÍNICA DA POPULAÇÃO DE ESTUDO}

A análise dos 87 pacientes com carcinoma espinocelular de língua ou assoalho de boca revelou um predomínio de pacientes do gênero masculino $(78,2 \%)$ e da raça branca $(92,0 \%)$, conforme descrito na Tabela 3.

A idade mínima obtida na época do diagnóstico foi de 35 anos e a máxima de 89 anos (idade média 59,36 anos e desvio padrão 10,91). A maioria dos pacientes apresentava idade menor ou igual a 59 anos $(51,7 \%)$, como pode ser visualizado na Tabela 3

A história clínica dos pacientes revelou que $82,8 \%$ destes eram tabagistas e $75,9 \%$ eram etilistas. A maioria dos pacientes $(73,6 \%)$ apresentou, simultaneamente, ambos os fatores de risco, tabaco e álcool, para o carcinoma espinocelular de boca (Tabela 3).

$\mathrm{Na}$ amostra estudada, os locais acometidos pelo carcinoma espinocelular foram a língua $(69 \%)$ e o assoalho de boca $(31 \%)$, conforme elucidado pela Tabela 4. Em 62,1\% dos espécimes, o tumor apresentava-se restrito ao seu local de origem, enquanto em alguns pacientes $(37,9 \%)$ a lesão estendia-se para outras áreas anatômicas adjacentes (Tabela 4), como gengiva, rebordo alveolar e loja amigdaliana. De acordo com as anotações dos 
respectivos prontuários médicos, em alguns pacientes o carcinoma espinocelular apresentava sua porção principal (maior diâmetro) localizada na língua com extensão adjacente para o assoalho bucal, em outros ocorria o inverso, a porção principal da neoplasia maligna localizava-se no assoalho de boca com extensão para a língua.

TABELA 3 - Distribuição de freqüência dos pacientes acometidos pelo carcinoma espinocelular de boca, segundo as características demográficas e os fatores de risco (tabaco e álcool). Hospital do Câncer A. C. Camargo, São Paulo, 1968 a 2001.

\section{Variável \\ Gênero} $\mathrm{N}^{\circ}$ de pacientes

$\%$

Masculino

68

78,2

Feminino

19

21,8

Raça

Branca

80

92,0

Não Branca

7

8,0

Idade

$\leq 59$ anos
$>59$ anos

45

51,7

42

48,3

Tabagismo

Não 9

10,3

Sim

Desconhecido

6

6,9

\section{Etilismo}

Não

15

17,2

Sim

66

75,9

Desconhecido

6

6,9

Tabagismo + etilismo

\begin{tabular}{lcc} 
Não & 17 & 19,5 \\
Sim & 64 & 73,6 \\
Desconhecido & 6 & 6,9 \\
\hline TOTAL & $\mathbf{8 7}$ & $\mathbf{1 0 0 , 0}$ \\
\hline \hline
\end{tabular}


No momento do exame clínico do paciente, $62,1 \%$ das neoplasias malignas apresentavam aspecto úlcero-infiltrativo e outras $(31 \%$ dos carcinomas espinocelulares) úlcero-vegetante. Em alguns pacientes o tumor mostrava-se com ambos os aspectos clínicos, úlcero-vegetante e infiltrativo. Em um paciente foi observado um aspecto nodular vegetante (Tabela 4).

Dentre as características clínicas analisadas a relação da neoplasia maligna com a linha média do paciente também foi levantada, porém em uma grande porcentagem $(44,8 \%)$ dos prontuários médicos esta informação estava ausente. Em 32,2\% dos pacientes, o carcinoma espinocelular de língua ou assoalho bucal respeitava a linha média, mas em 23,0\% o tumor comprometia a mesma (Tabela 4).

Em relação ao estadiamento clínico $\mathrm{T}$, no momento do diagnóstico, $32,2 \%$ dos pacientes apresentavam carcinomas espinocelulares de boca com diâmetro igual ou inferior a dois centímetros, classificados como T1 e 67,8\% dos pacientes apresentavam tumores com diâmetro entre dois e quatro centímetros, classificados como T2, conforme os critérios de estadiamento clínico do sistema TNM, definidos pela UICC ${ }^{31,58}$. Verificou-se que nenhum destes pacientes apresentou linfonodos regionais clinicamente palpáveis no momento do exame físico (N0), como pode ser observado na Tabela 4.

O menor tempo de duração dos carcinomas espinocelulares, de acordo com a informação dos pacientes, foi de 15 dias (relato de dois pacientes) e o maior de 60 meses (tempo médio 5,94 meses e desvio padrão 8,02), tendo a maioria dos pacientes $(72,2 \%)$ procurado o Hospital do Câncer A. C. Camargo, São Paulo, nos seis primeiros meses de surgimento do tumor, conforme descrito na Tabela 4. 
TABELA 4 - Distribuição de freqüência dos pacientes acometidos pelo carcinoma espinocelular de boca, segundo as características clínicas e a história clínica. Hospital do Câncer A. C. Camargo, São Paulo, 1968 a 2001.

\begin{tabular}{lll}
\hline Variável & $N^{\circ}$ de pacientes & $\%$ \\
\hline
\end{tabular}

\section{Localização da lesão}

Língua

60

69,0

Assoalho de boca

27

31,0

Extensão da lesão

Restrita ao local de origem

54

62,1

Extensão anatômica adjacente

33

37,9

Aspecto da lesão

Úlcero-vegetante

27

31,0

Úlcero-infiltrativa

54

62,1

Outro

6

6,9

Relação com a linha média

Não compromete

Compromete

20

23,0

Desconhecido

39

44,8

Estadiamento T

T1

28

32,2

T2

59

67,8

\section{Estadiamento $\mathbf{N}$}

NO

87

100,0

Tempo de história clínica

\begin{tabular}{ccc}
$\leq 6$ meses & 63 & 72,2 \\
$>6$ meses & 20 & 23,2 \\
Desconhecido & 4 & 4,6 \\
\hline TOTAL & $\mathbf{8 7}$ & $\mathbf{1 0 0 , 0}$ \\
\hline
\end{tabular}

De acordo com os critérios de inclusão dos pacientes no estudo, $100 \%$ foram submetidos à cirurgia como tratamento inicial do carcinoma espinocelular de língua ou assoalho de boca. Em 63,2\% destes pacientes foi realizado esvaziamento cervical ipsilateral e em 10,4\% o esvaziamento cervical bilateral, ou seja, ipsilateral e contralateral simultaneamente. Dos oitenta e sete 
pacientes com carcinoma espinocelular de boca e estadiamento clínico inicial, vinte e três $(26,4 \%)$ não foram submetidos à dissecação linfonodal do pescoço (Tabela 5).

Ainda com relação ao tratamento, $21,8 \%$ dos pacientes foram submetidos à radioterapia pós-operatória adjuvante, entretanto, na maioria $(78,2 \%)$ este tipo de tratamento não foi utilizado, em concordância ao que mostra a Tabela 5. Nenhum dos pacientes da amostra foi submetido à quimioterapia pré ou pós-operatória, conforme os critérios de inclusão previamente estabelecidos.

Durante a evolução clínica, a ocorrência de recidiva local e metástase regional foi observada em $17,2 \%$ e $13,8 \%$ dos pacientes com carcinoma espinocelular de boca, respectivamente (Tabela 5). Três pacientes apresentaram recidiva local e metástase regional simultaneamente. Na grande maioria dos pacientes desta casuística $(97,7 \%)$ não foi detectado metástase à distância. Apenas dois pacientes apresentaram comprometimento metastático durante o seguimento clínico, sendo um no pulmão e outro no fígado.

A maioria dos pacientes da amostra estudada não desenvolveu uma segunda neoplasia primária no período de seguimento avaliado, todavia, constatou-se um segundo tumor primário em vinte e sete $(31,0 \%)$ dos pacientes com carcinoma espinocelular de boca (Tabela 5).

\section{3 - ANÁLISE MICROSCÓPICA}

Os cortes microscópicos obtidos a partir das peças cirúrgicas do tumor primário, que estavam arquivadas no Departamento de Anatomia Patológica do Hospital do Câncer A. C. Camargo, foram analisados em H.E. (FIGURAS 4, 5 e 6) quanto à graduação da malignidade no front de invasão tumoral, quanto à embolização vascular e quanto às infiltrações perineural, muscular e glandular. Além disso, analisou-se, microscopicamente, a expressão de VEGF-C pelas células malignas utilizando-se a técnica imunohistoquímica (FIGURAS 7 e 8). 
TABELA 5 - Distribuição de freqüência dos pacientes acometidos pelo carcinoma espinocelular de boca, segundo o tratamento e a evolução clínica. Hospital do Câncer A. C. Camargo, São Paulo, 1968 a 2001.

Variável $N^{\circ}$ de pacientes

$\%$

\section{Esvaziamento cervical}

Ipsilateral 55

63,2

Bilateral

9

10,4

Sem esvaziamento

23

26,4

Radioterapia adjuvante

Não

Sim

Recidiva local

Não

Sim

Metástase regional

Não

Sim

Metástase à distância

Não

Sim

Segundo tumor primário

\begin{tabular}{rcc} 
Não & 60 & 69,0 \\
Sim & 27 & 31,0 \\
\hline TOTAL & $\mathbf{8 7}$ & $\mathbf{1 0 0 , 0}$ \\
\hline
\end{tabular}

\subsection{1 - Graduação da Malignidade Tumoral}

As características morfológicas analisadas para a graduação da malignidade na região do front de invasão tumoral foram: o grau de queratinização, o polimorfismo nuclear, o número de mitoses, o padrão de invasão tumoral e a resposta do hospedeiro frente ao tumor (APÊNDICE C), conforme a graduação histopatológica de malignidade proposta por BRYNE et al. ${ }^{11}, 1989$. Os resultados obtidos e a distribuição de freqüência dos carcinomas espinocelulares de boca, segundo as características microscópicas analisadas, podem ser visualizados na Tabela 6. 
A maioria dos carcinomas espinocelulares de boca analisados consistia em tumores bem a moderadamente diferenciados caracterizados microscopicamente por intensa (Figura 4A) a moderada queratinização, discreto a moderado polimorfismo nuclear, zero a três figuras de mitoses (Figura 5A) por campo microscópico e intenso a moderado infiltrado inflamatório mononuclear. O padrão de invasão caracterizado por cordões sólidos/grossos de células neoplásicas (Figura 4A) foi o mais freqüentemente observado (Tabela 6).

TABELA 6 - Distribuição de freqüência dos 87 carcinomas espinocelulares de boca, segundo o sistema de graduação de malignidade, do front de invasão tumoral, de BRYNE et al. ${ }^{11}$ Hospital do Câncer A. C. Camargo, São Paulo, 1968 a 2001.

\begin{tabular}{|c|c|c|c|c|}
\hline \multirow{2}{*}{$\begin{array}{l}\text { CARACTERÍSTICAS } \\
\text { MORFOLÓGICAS }\end{array}$} & \multicolumn{4}{|c|}{ ESCORES DE MALIGNIDADE } \\
\hline & 1 & 2 & 3 & 4 \\
\hline $\begin{array}{l}\text { Grau de } \\
\text { queratinização }\end{array}$ & $\begin{array}{c}25 \\
(28,7 \%)\end{array}$ & $\begin{array}{c}27 \\
(31,0 \%)\end{array}$ & $\begin{array}{c}24 \\
(27,6 \%)\end{array}$ & $\begin{array}{c}11 \\
(12,6 \%)\end{array}$ \\
\hline $\begin{array}{l}\text { Polimorfismo } \\
\text { nuclear }\end{array}$ & $\begin{array}{c}35 \\
(40,2 \%)\end{array}$ & $\begin{array}{c}31 \\
(35,6 \%)\end{array}$ & $\begin{array}{c}18 \\
(20,7 \%)\end{array}$ & $\begin{array}{c}3 \\
(3,4 \%)\end{array}$ \\
\hline Número de mitoses & $\begin{array}{c}15 \\
(17,2 \%)\end{array}$ & $\begin{array}{c}50 \\
(57,5 \%)\end{array}$ & $\begin{array}{c}21 \\
(24,1 \%)\end{array}$ & $\begin{array}{c}1 \\
(1,1 \%)\end{array}$ \\
\hline Padrão de invasão & $\begin{array}{c}13 \\
(14,9 \%)\end{array}$ & $\begin{array}{c}44 \\
(50,6 \%)\end{array}$ & $\begin{array}{c}29 \\
(33,3 \%)\end{array}$ & $\begin{array}{c}1 \\
(1,1 \%)\end{array}$ \\
\hline $\begin{array}{l}\text { Resposta do } \\
\text { hospedeiro }\end{array}$ & $\begin{array}{c}38 \\
(43,7 \%)\end{array}$ & $\begin{array}{c}36 \\
(41,4 \%)\end{array}$ & $\begin{array}{c}13 \\
(14,9 \%)\end{array}$ & $\begin{array}{c}0 \\
(0,0 \%)\end{array}$ \\
\hline
\end{tabular}

A variação do escore final de malignidade dos carcinomas espinocelulares de boca foi de 6 a 16 pontos. A maior parte da amostra $(79,3 \%)$ consistia de tumores bem a moderadamente diferenciados, ou seja, pouco agressivos, como descrito na Tabela 7. 
TABELA 7 - Distribuição de freqüência dos carcinomas espinocelulares de boca, segundo a graduação de malignidade tumoral. Hospital do Câncer A. C. Camargo, São Paulo, 1968 a 2001.

\begin{tabular}{llc}
\hline \hline Graduação de malignidade & $\mathbf{N}^{\circ}$ & $\%$ \\
\hline Pouco agressivo $(\leq 12)$ & 69 & 79,3 \\
Muito agressivo $(>12)$ & 18 & 20,7 \\
\hline TOTAL & $\mathbf{8 7}$ & $\mathbf{1 0 0 , 0}$ \\
\hline \hline
\end{tabular}

$\mathrm{N}^{\circ}$ : número de carcinomas espinocelulares de língua e assoalho de boca

Quanto às características histopatológicas de infiltração tumoral a maioria dos pacientes não apresentou embolização vascular $(59,8 \%)$, dos que apresentaram, 26,4\% eram embolizações linfáticas e $11,5 \%$ eram do tipo sangüínea, sendo que dois pacientes $(2,6 \%)$ apresentaram embolização angiolinfática. A infiltração perineural (Figura 6) mostrou-se presente em 50,6\% dos espécimes observados e $81,6 \%$ dos carcinomas espinocelulares analisados apresentaram infiltração muscular (Figura 5B). Somente 33,3\% dos tumores apresentavam infiltração de glândula salivar contra 66,7\% sem este tipo de infiltração (Tabela 8).

A grande maioria das peças cirúrgicas removidas dos pacientes não apresentava comprometimento das margens (96,6\%), porém em três pacientes $(3,4 \%)$ as margens estavam comprometidas pelo carcinoma espinocelular.

Dos oitenta e sete pacientes, $73,6 \%$ foram submetidos ao esvaziamento cervical, quatorze deles $(16,1 \%)$ apresentaram comprometimento linfonodal cervical, comprovado pela análise histopatológica $(\mathrm{pN}+)$, sendo que um destes pacientes apresentou comprometimento bilateral. A maioria dos pacientes $(57,5 \%)$ submetidos ao esvaziamento cervical eletivo estava livre de metástase regional, conforme o exame histopatológico (pN0), o que pode ser observado na Tabela 8.

$\mathrm{Na}$ amostra estudada 64 pacientes foram submetidos ao esvaziamento cervical eletivo e destes $21,9 \%$ apresentaram metástases ocultas nos linfonodos cervicais $(\mathrm{pN}+)$. 
TABELA 8 - Distribuição de freqüência dos carcinomas espinocelulares de boca, segundo as características histopatológicas e o comprometimento linfonodal. Hospital do Câncer A. C. Camargo, São Paulo, 1968 a 2001.

\begin{tabular}{lll}
\hline \hline Variável & $\mathrm{N}^{\circ}$ & $\%$ \\
\hline
\end{tabular}

\section{Embolização vascular}

Linfática

Sangüínea

Ambas

Ausente
23

10

2

52

43

44

Presente

Ausente

16

71

Presente
18,4

Infiltração de glândula salivar

Ausente

58

29

Presente

\section{Margens cirúrgicas}

Livres

Comprometidas

\section{Esvaziamento cervical}

pNO

$\mathrm{pN}+$

Sem esvaziamento
84

3

50

14

23
26,4

11,5

2,3

59,8

\section{TOTAL}

50,6

No: número de carcinomas espinocelulares de língua e assoalho de boca; pN0: ausência de comprometimento linfonodal cervical histopatológico; $\mathrm{pN}+$ : presença de comprometimento linfonodal cervical histopatológico. 

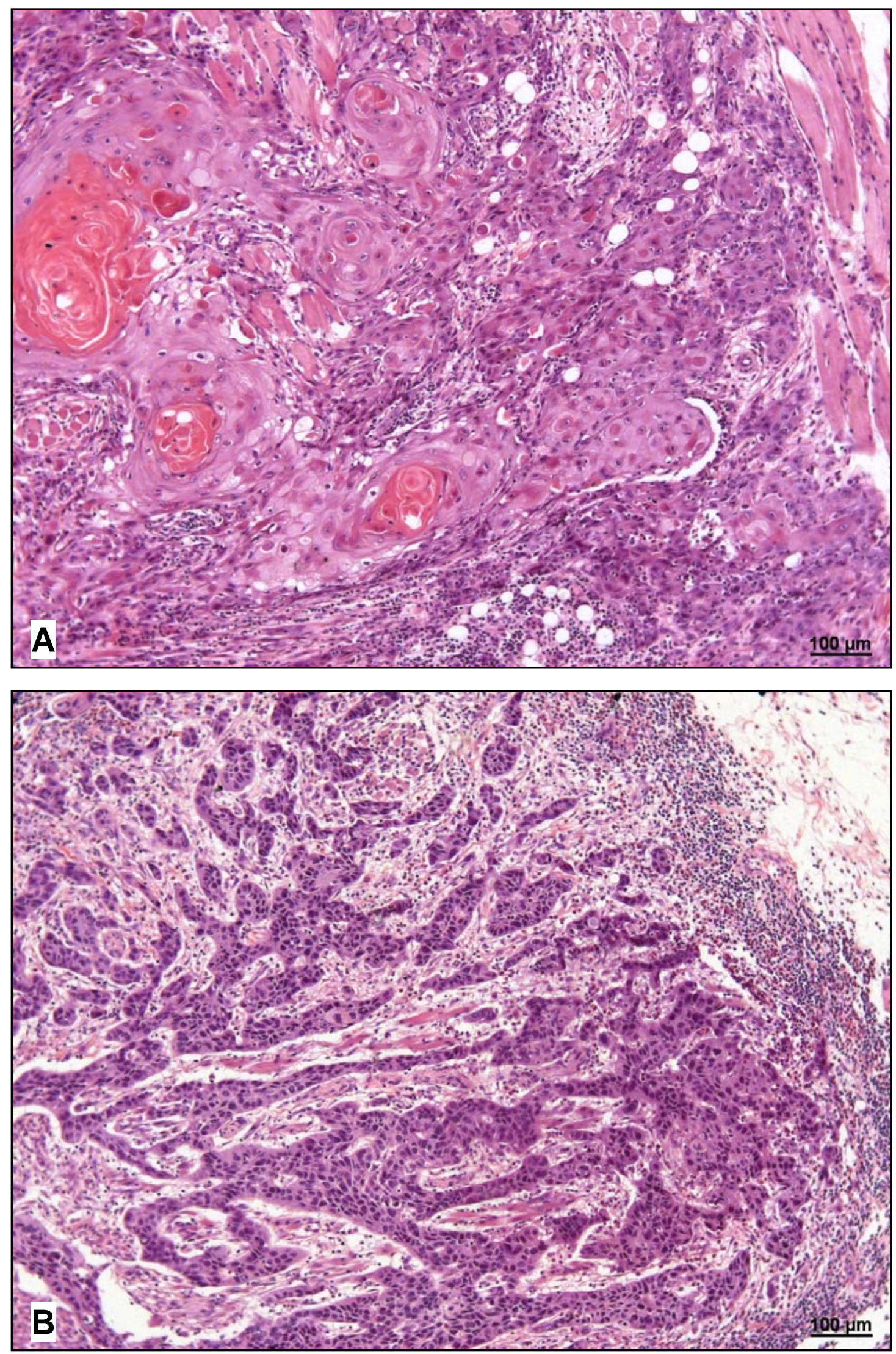

Figura 4 - Carcinoma espinocelular de boca com intensa queratinização e padrão de invasão em cordões grossos (A). Em B, observar CEC de boca pouco queratinizado e com padrão de invasão em cordões finos. (HE, aumento original de $63 \mathrm{X}$ em A e B). 

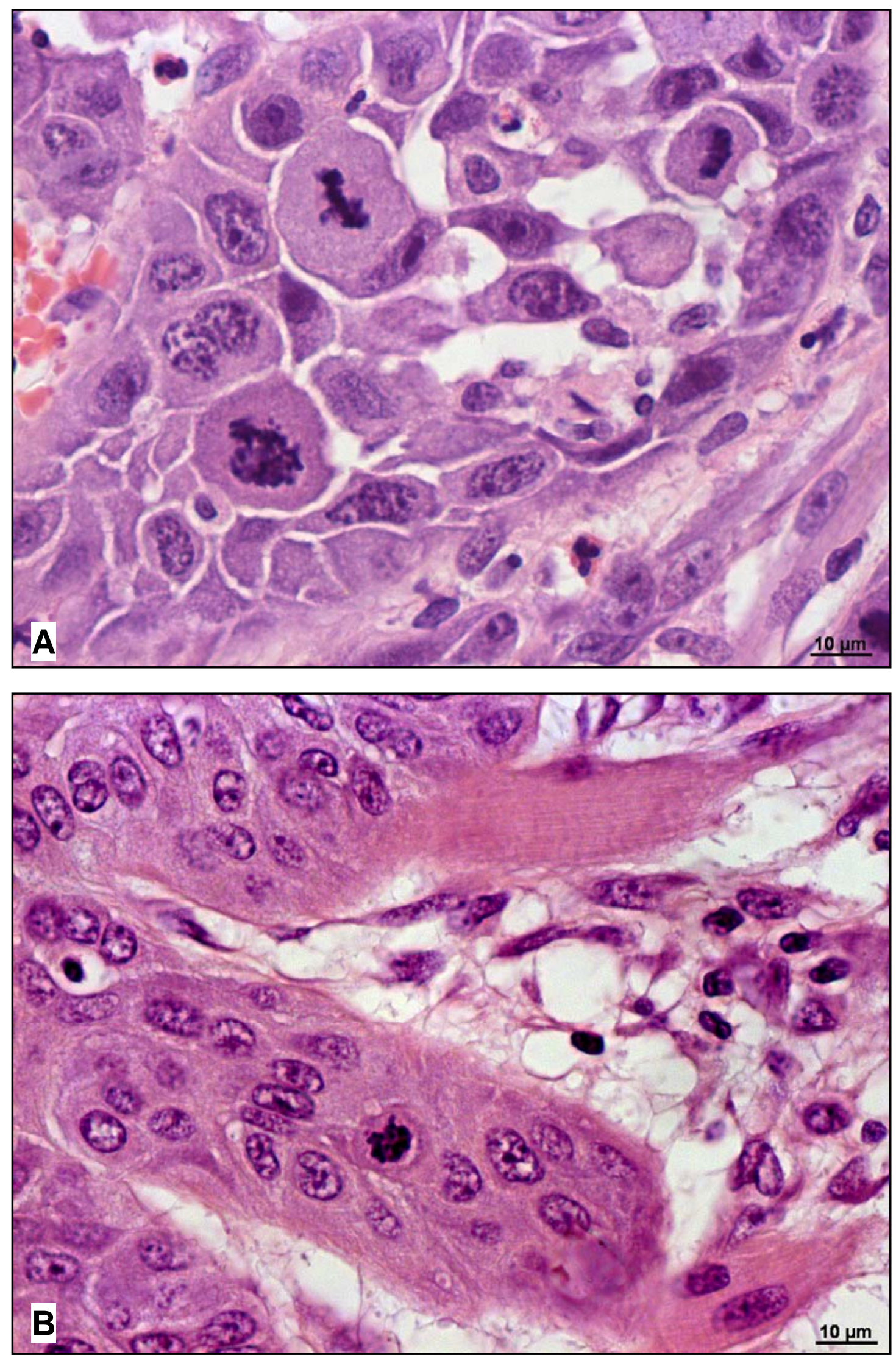

Figura 5 - Algumas figuras de mitose do carcinoma espinocelular de boca (A). Em B, observar a infiltração muscular do CEC de boca. (HE, aumento original de $630 \mathrm{X}$ em $\mathrm{A}$ e B). 

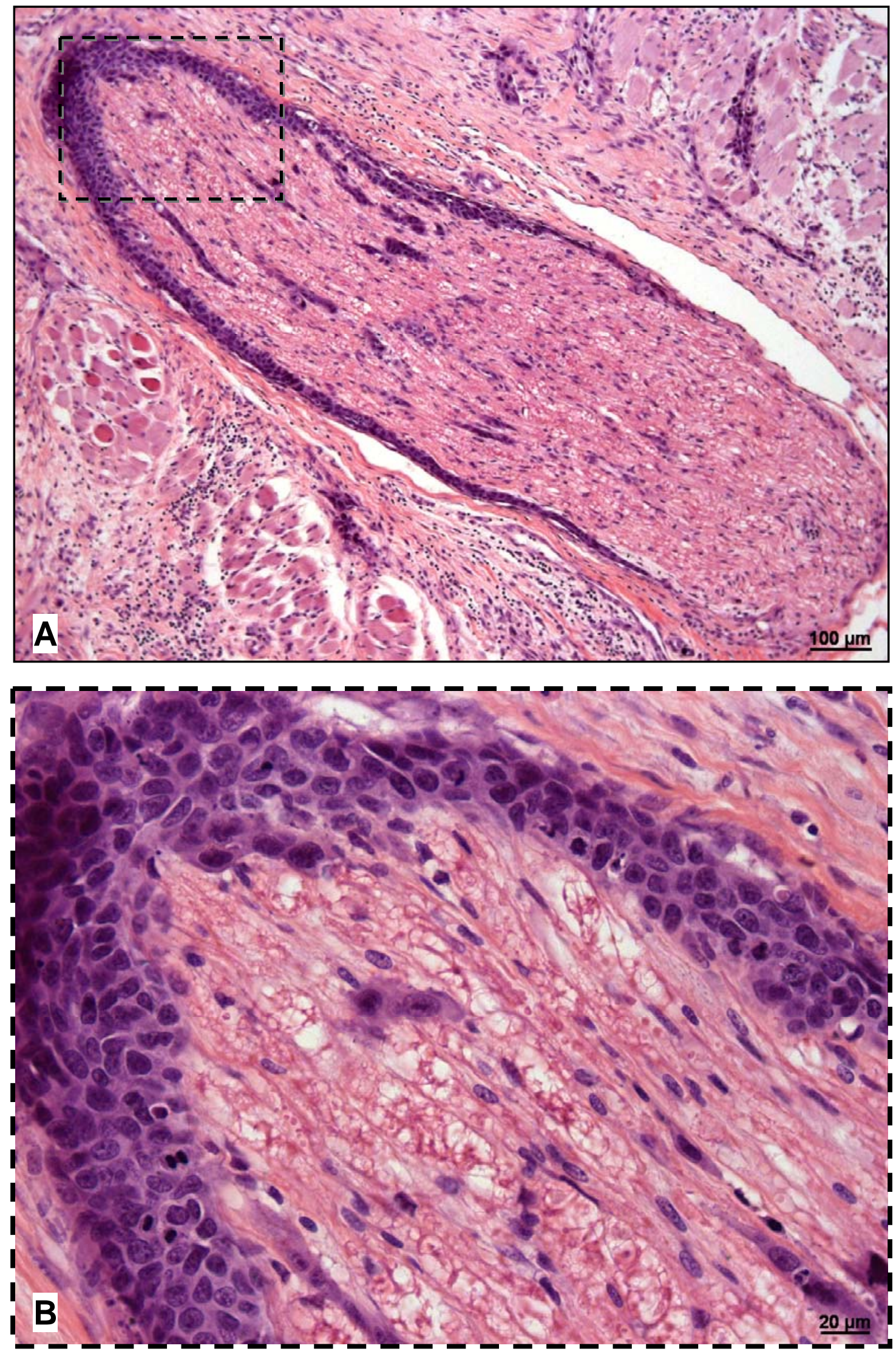

Figura 6 - Infiltração perineural do CEC de boca (A). Observar no detalhe (B) a presença de cordões finos de células neoplásicas circundando e permeando as células neurais. (HE, aumento original de $63 \mathrm{X}$ em A e de $252 X$ em B). 


\subsection{2 - Avaliação Imuno-Histoquímica}

A expressão citoplasmática do anticorpo anti-VEGF-C nos carcinomas espinocelulares de língua e assoalho de boca, não mostrou correlação com as principais variáveis demográficas e clínicas (Tabela 9) e com a evolução clínica (recidiva local e metástase regional) e as variáveis microscópicas de infiltração neoplásica (Tabela 10), incluindo embolização angiolinfática e infiltrações perineural, muscular e de glândula salivar.

A associação entre o comprometimento linfonodal cervical histopatológico (metástase oculta) e a expressão citoplasmática do anticorpo anti-VEGF-C nos carcinomas espinocelulares de boca, está distribuída na Tabela 11.

Sessenta e quatro pacientes com carcinomas espinocelulares de boca foram submetidos ao esvaziamento cervical eletivo e, destes, a maioria apresentou uma forte expressão citoplasmática do anticorpo anti-VEGF-C (84,0\% pN0 e $85,7 \%$ pN+).

Não foi verificada associação estatisticamente significativa $(p=0,876)$ entre a expressão imuno-histoquímica do anticorpo anti-VEGF-C (fraco ou forte) pelas células malignas e o comprometimento linfonodal cervical histopatológico (metástase oculta) dos pacientes com CEC de boca, conforme a Tabela 11.

Quando observada a distribuição da expressão citoplasmática do anticorpo anti-VEGF-C nos carcinomas espinocelulares de boca em relação à graduação de malignidade, determinada no front de invasão tumoral conforme proposto por BRYNE et al. ${ }^{11}$, em 1989, pode-se constatar que, independente do índice de malignidade, os tumores pouco ou muito agressivos apresentaram uma forte expressão imuno-histoquímica de VEGF-C (Tabela 12).

Estatisticamente não foi observada diferença significativa $(p=0,406)$ entre a expressão de VEGF-C pelas células malignas e a graduação de malignidade tumoral (Tabela 12).

Os padrões de expressão imuno-histoquímica do VEGF-C pelas células neoplásicas podem ser observados nas Figuras 7 e 8. 
TABELA 9 - Distribuição da expressão imuno-histoquímica do anticorpo antiVEGF-C nos carcinomas espinocelulares de boca, segundo alg variáveis demográficas e clínicas. Hospital do Câncer A. C. Camargo, São Paulo, 1968 a 2001.

\begin{tabular}{|c|c|c|c|c|c|}
\hline \multirow{3}{*}{$\begin{array}{l}\text { Variável } \\
\text { Gênero }\end{array}$} & \multicolumn{4}{|c|}{ VEGF-C } & \multirow{3}{*}{$p$} \\
\hline & \multicolumn{2}{|c|}{ fraco } & \multicolumn{2}{|c|}{ forte } & \\
\hline & $\mathbf{N}^{\circ}$ & $\%$ & $\mathbf{N}^{\circ}$ & $\%$ & \\
\hline Masculino & 16 & 76,2 & 52 & 78,8 & \multirow{2}{*}{0,802} \\
\hline Feminino & 5 & 23,8 & 14 & 21,2 & \\
\hline \multicolumn{6}{|l|}{ Raça } \\
\hline Branca & 20 & 95,2 & 60 & 90,9 & \multirow{2}{*}{0,525} \\
\hline Não branca & 1 & 4,8 & 6 & 9,1 & \\
\hline \multicolumn{6}{|l|}{ Idade } \\
\hline$\leq 59$ anos & 10 & 47,6 & 35 & 53,0 & \multirow{2}{*}{0,666} \\
\hline$>59$ anos & 11 & 52,4 & 31 & 47,0 & \\
\hline \multicolumn{6}{|l|}{ Tabagismo } \\
\hline Não & 3 & 15,0 & 6 & 9,8 & \multirow{2}{*}{0,524} \\
\hline Sim & 17 & 85,0 & 55 & 90,2 & \\
\hline \multicolumn{6}{|l|}{ Etilismo $^{\#}$} \\
\hline Não & 4 & 20,0 & 11 & 18,0 & \multirow{2}{*}{0,844} \\
\hline Sim & 16 & 80,0 & 50 & 82,0 & \\
\hline \multicolumn{6}{|c|}{ Tabagismo + Etilismo } \\
\hline Não & 4 & 20,0 & 13 & 21,3 & \multirow{2}{*}{0,901} \\
\hline Sim & 16 & 80,0 & 48 & 78,7 & \\
\hline \multicolumn{6}{|l|}{ Local do tumor } \\
\hline Língua & 16 & 76,2 & 44 & 66,7 & \multirow{2}{*}{0,411} \\
\hline Assoalho & 5 & 23,8 & 22 & 33,3 & \\
\hline \multicolumn{6}{|l|}{ Estadiamento T } \\
\hline $\mathrm{T} 1$ & 10 & 47,6 & 18 & 27,3 & \multirow{2}{*}{0,082} \\
\hline $\mathrm{T} 2$ & 11 & 52,4 & 48 & 72,7 & \\
\hline TOTAL & 21 & 100,0 & 66 & 100,0 & \\
\hline
\end{tabular}

$p$ : nível descritivo do teste qui-quadrado; $\mathrm{N}^{\circ}$ : número de carcinomas espinocelulares de língua e assoalho de boca; *: excluídos os pacientes com informação desconhecida. 
TABELA 10 -Distribuição da expressão imuno-histoquímica do anticorpo antiVEGF-C nos carcinomas espinocelulares de boca, segundo a evolução clínica e as variáveis microscópicas de infiltração neoplásica. Hospital do Câncer A. C. Camargo, São Paulo, 1968 a 2001.

\begin{tabular}{|c|c|c|c|c|c|}
\hline \multirow{3}{*}{$\begin{array}{l}\text { Variável } \\
\text { Recidiva local }\end{array}$} & \multicolumn{4}{|c|}{ VEGF-C } & \multirow{3}{*}{$p$} \\
\hline & \multicolumn{2}{|c|}{ fraco } & \multicolumn{2}{|c|}{ forte } & \\
\hline & $\mathbf{N}^{\circ}$ & $\%$ & $\mathbf{N}^{\mathbf{o}}$ & $\%$ & \\
\hline Ausente & 19 & 90,5 & 53 & 80,3 & תסת \\
\hline Presente & 2 & 9,5 & 13 & 19,7 & 0,202 \\
\hline
\end{tabular}

Metástase regional

$\begin{array}{lccccc}\text { Ausente } & 17 & 81,0 & 56 & 84,8 & 0,672 \\ \text { Presente } & 4 & 19,0 & 10 & 15,2 & \end{array}$

Embolização linfática

$\begin{array}{lccccc}\text { Ausente } & 16 & 76,2 & 46 & 69,7 & 0,567 \\ \text { Presente } & 5 & 23,8 & 20 & 30,3 & \end{array}$

\section{Embolização sangüínea}

$\begin{array}{lccccc}\text { Ausente } & 19 & 90,5 & 56 & 84,8 & 0,515 \\ \text { Presente } & 2 & 9,5 & 10 & 15,2 & \end{array}$

Infiltração perineural

$\begin{array}{lccccc}\text { Ausente } & 9 & 42,9 & 34 & 51,5 & 0,489 \\ \text { Presente } & 12 & 57,1 & 32 & 48,5 & \end{array}$

Infiltração muscular

$\begin{array}{lccccc}\text { Ausente } & 3 & 14,3 & 13 & 19,7 & 0,577 \\ \text { Presente } & 18 & 85,7 & 53 & 80,3 & \end{array}$

Infiltração glandular

\begin{tabular}{cccccc} 
Ausente & 16 & 76,2 & 42 & 63,6 & 0,288 \\
Presente & 5 & 23,8 & 24 & 36,4 & \\
\hline TOTAL & $\mathbf{2 1}$ & $\mathbf{1 0 0 , 0}$ & $\mathbf{6 6}$ & $\mathbf{1 0 0 , 0}$ & \\
\hline \hline
\end{tabular}

$p$ : nível descritivo do teste qui-quadrado; $\mathrm{N}^{0}$ : número de carcinomas espinocelulares de língua e assoalho de boca. 
TABELA 11 -Distribuição da expressão imuno-histoquímica do anticorpo antiVEGF-C nos carcinomas espinocelulares de boca, segundo o comprometimento linfonodal cervical histopatológico. Hospital do Câncer A. C. Camargo, São Paulo, 1968 a 2001.

\begin{tabular}{|c|c|c|c|c|c|c|c|}
\hline \multirow{3}{*}{$\begin{array}{l}\text { Variável } \\
\text { Comprometimento } \\
\text { linfonodal }^{\#}\end{array}$} & \multicolumn{4}{|c|}{ VEGF-C } & \multirow{2}{*}{\multicolumn{2}{|c|}{ Total }} & \multirow{3}{*}{$p$} \\
\hline & \multicolumn{2}{|c|}{ fraco } & \multicolumn{2}{|c|}{ forte } & & & \\
\hline & $\mathbf{N}^{\circ}$ & $\%$ & $\mathbf{N}^{\circ}$ & $\%$ & $\mathbf{N}^{\circ}$ & $\%$ & \\
\hline pNo & 8 & 16,0 & 42 & 84,0 & 50 & 100 & \\
\hline $\mathrm{pN}+$ & 2 & 14,3 & 12 & 85,7 & 14 & 100 & \\
\hline
\end{tabular}

$\overline{p: \text { nível descritivo do teste qui-quadrado; } \mathrm{N}^{0}: \text { número de }} \overline{\overline{\text { carcinomas espinocelulares de língua }}} \overline{\overline{ }} \overline{\overline{ }} \overline{\overline{\text { and }}}$ e assoalho de boca; pN0: ausência de comprometimento linfonodal cervical histopatológico; $\mathrm{pN+:}$ presença de comprometimento linfonodal cervical histopatológico; \#: excluídos os pacientes não submetidos ao esvaziamento cervical.

TABELA 12 -Distribuição da expressão imuno-histoquímica do anticorpo antiVEGF-C nos carcinomas espinocelulares de boca, segundo a graduação de malignidade tumoral. Hospital do Câncer A. C. Camargo, São Paulo, 1968 a 2001.

\begin{tabular}{|c|c|c|c|c|c|c|c|}
\hline \multirow{3}{*}{$\begin{array}{l}\text { Variável } \\
\begin{array}{l}\text { Graduação de } \\
\text { malignidade }\end{array}\end{array}$} & \multicolumn{4}{|c|}{ VEGF-C } & \multirow{2}{*}{\multicolumn{2}{|c|}{ Total }} & \multirow{3}{*}{$p$} \\
\hline & \multicolumn{2}{|c|}{ fraco } & \multicolumn{2}{|c|}{ forte } & & & \\
\hline & $\mathbf{N}^{\circ}$ & $\%$ & $\mathbf{N}^{\mathbf{O}}$ & $\%$ & $N^{0}$ & $\%$ & \\
\hline Pouco agressivo & 18 & 26,1 & 51 & 73,9 & 69 & 100 & \\
\hline Muito agressivo & 3 & 16,7 & 15 & 83,3 & 18 & 100 & \\
\hline
\end{tabular}

$\overline{p: \text { nível descritivo do teste qui-quadrado; } \mathrm{N}^{0} \text { : número de }} \overline{\overline{\text { carcinomas espinocelulares de língua }}}$ e assoalho de boca. 

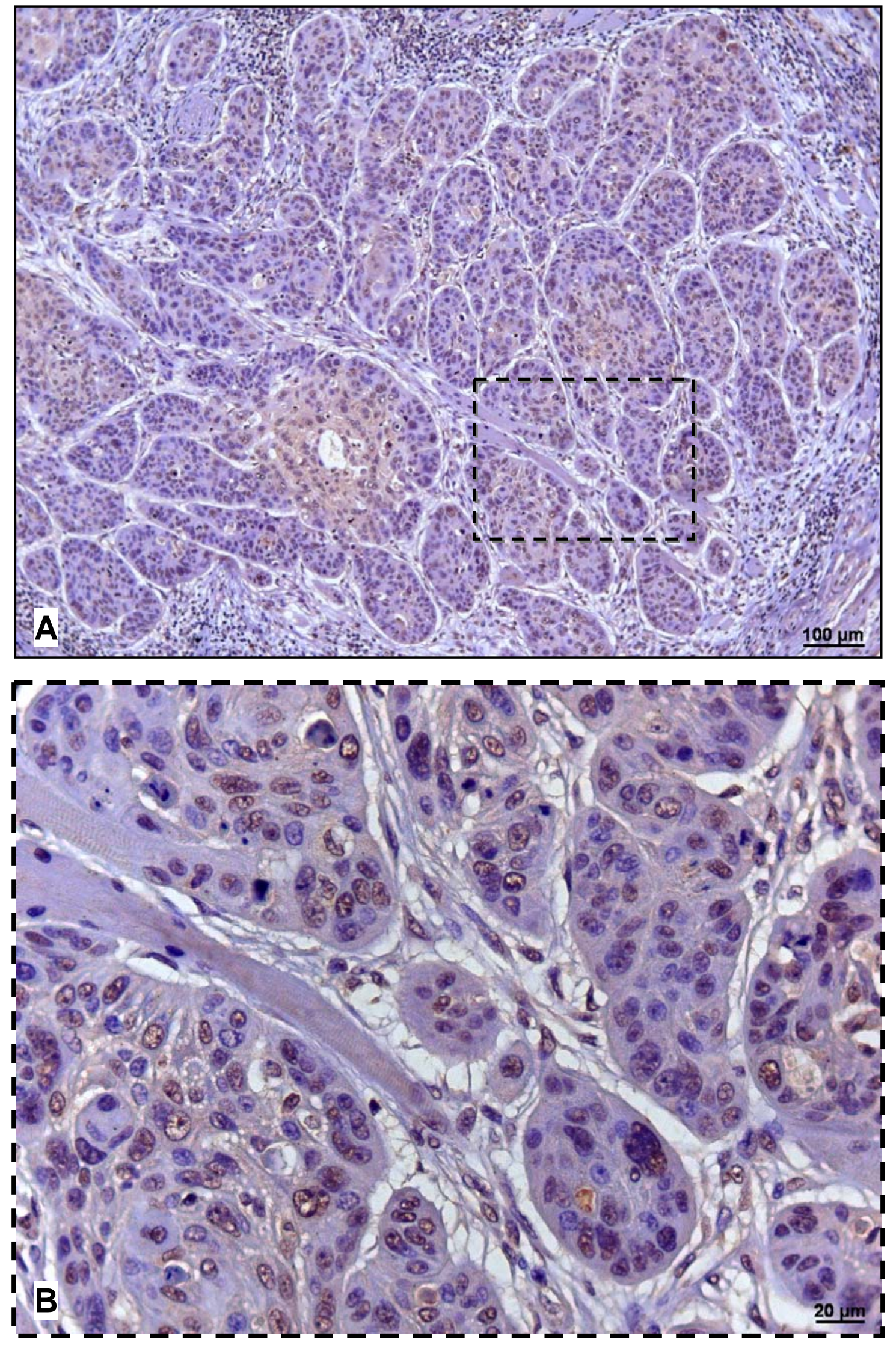

Figura 7 - Expressão imuno-histoquímica fraca do anticorpo anti-VEGF-C no CEC de boca $(A)$. Em $B$, observar o detalhe da área neoplásica demarcada em A. (IHQ, aumento original de 63X em A e de 252X em B). 

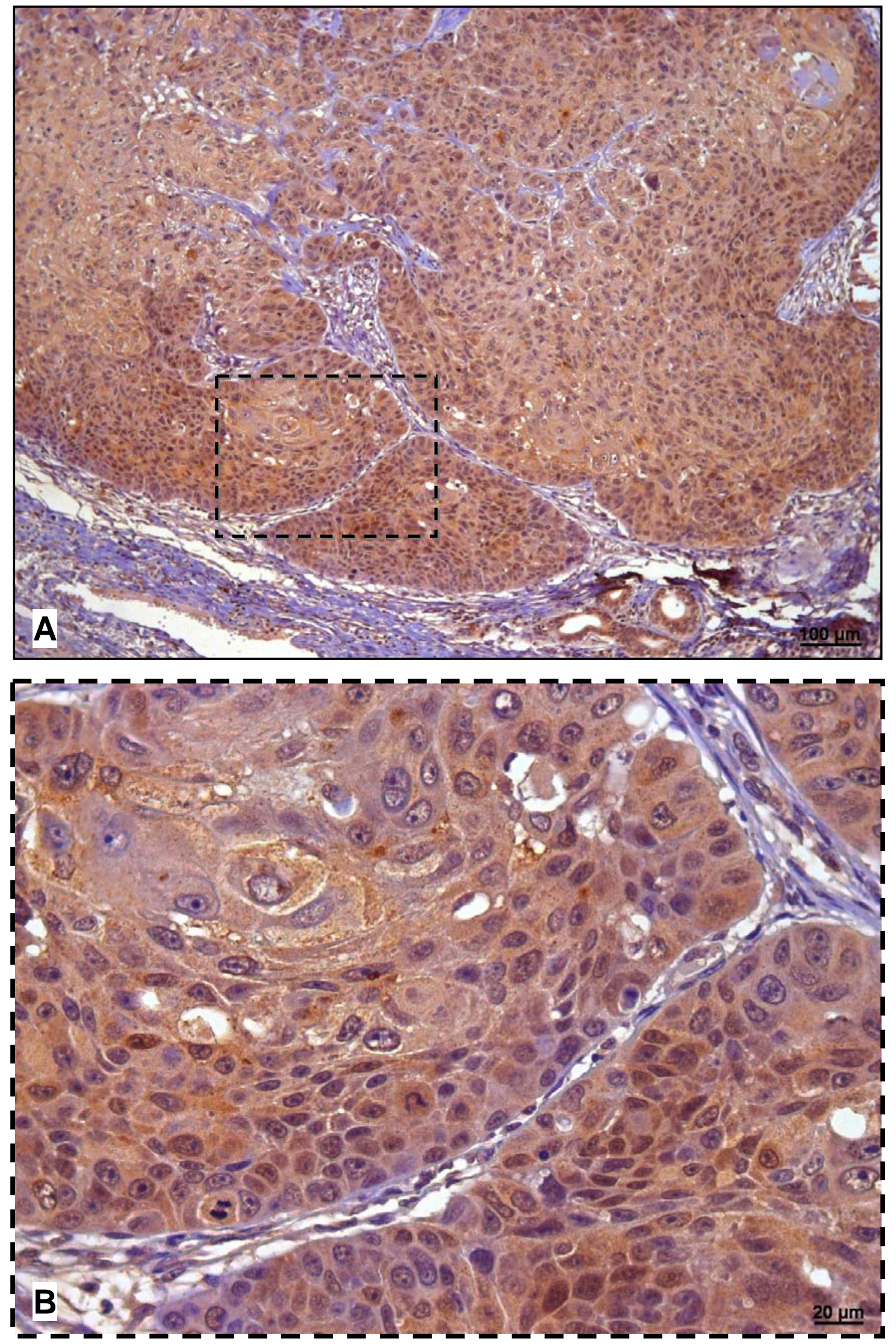

Figura 8 - Expressão imuno-histoquímica forte do anticorpo anti-VEGF-C no CEC de boca $(A)$. Em $B$, detalhe da área demarcada em $A$ mostrando células neoplásicas fortemente coradas pelo VEGF-C. (IHQ, aumento original de 63X em A e de 252X em B). 


\section{4 - ANÁLISE DE SOBREVIDA}

O período de seguimento clínico dos 87 pacientes com carcinoma espinocelular de língua e assoalho de boca, estádios I e II, variou de 5,43 a 272,14 meses (média 82,2 meses, desvio padrão 63,14). Ao final do período de seguimento, trinta e três pacientes $(37,9 \%)$ estavam vivos e sem evidência de recidiva da doença, dezenove pacientes $(21,8 \%)$ tiveram morte decorrente da recorrência do tumor primário (local, regional ou à distância), vinte e oito pacientes $(32,2 \%)$ morreram por outras causas não relacionadas ao tumor e sete $(8,0 \%)$ apresentavam menos de cinco anos de seguimento sendo, portanto, considerados perdidos de vista.

As probabilidades das sobrevidas global, livre de doença e específica por câncer acumuladas no período de cinco e dez anos com relação a expressão de VEGF-C, foram calculadas pelo estimador produto-limite de Kaplan-Meier. A comparação entre as curvas de sobrevida foi realizada pelo teste log-rank com o nível de significância igual a 5\%.

Não se detectou diferença estatística entre as probabilidades de sobrevidas global, livre de doença e específica por câncer com relação a expressão do anticorpo anti-VEGF-C. As Tabelas 13 e 14, bem como as Figuras 9, 10 e 11, apresentam as probabilidades de sobrevidas global, livre de doença e específica por câncer acumuladas em cinco e dez anos.

TABELA 13 -Distribuição da expressão imuno-histoquímica do anticorpo antiVEGF-C nos carcinomas espinocelulares de boca, conforme as sobrevidas global e livre de doença para cinco e dez anos. Hospital do Câncer A. C. Camargo, São Paulo, 1968 a 2001.

\begin{tabular}{ccccccc}
\hline \hline & \multicolumn{3}{c}{ Sobrevida global } & \multicolumn{3}{c}{ Sobrevida livre de doença } \\
Variável & $\begin{array}{c}\mathbf{5} \text { anos } \\
\mathbf{( \% )}\end{array}$ & $\begin{array}{c}\mathbf{1 0} \text { anos } \\
\mathbf{( \% )}\end{array}$ & $\boldsymbol{p}$ & $\begin{array}{c}\mathbf{5} \text { anos } \\
\mathbf{( \% )}\end{array}$ & $\begin{array}{c}\mathbf{1 0} \text { anos } \\
\mathbf{( \% )}\end{array}$ & $\boldsymbol{p}$ \\
\hline VEGF-C & & & & & & \\
fraco & 63,2 & 52,6 & & 6,682 & 64,9 & 6,975 \\
forte & 62,3 & 45,5 & & 65,5 & 65,5 & \\
\hline \hline
\end{tabular}

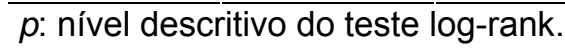


TABELA 14 -Distribuição da expressão imuno-histoquímica do anticorpo antiVEGF-C nos carcinomas espinocelulares de boca, conforme a sobrevida específica por câncer para cinco e dez anos. Hospital do Câncer A. C. Camargo, São Paulo, 1968 a 2001.

\begin{tabular}{cccc}
\hline \hline & \multicolumn{3}{c}{ Sobrevida específica por câncer } \\
Variável & $\begin{array}{c}\mathbf{5} \text { anos } \\
\mathbf{( \% )}\end{array}$ & $\begin{array}{c}\mathbf{1 0} \text { anos } \\
\mathbf{( \% )}\end{array}$ & $\boldsymbol{p}$ \\
\hline VEGF-C & & & \\
fraco & 82,4 & 82,4 & 0,379 \\
forte & 74,5 & 71,4 & 0 \\
\hline \hline
\end{tabular}

p: nível descritivo do teste log-rank.

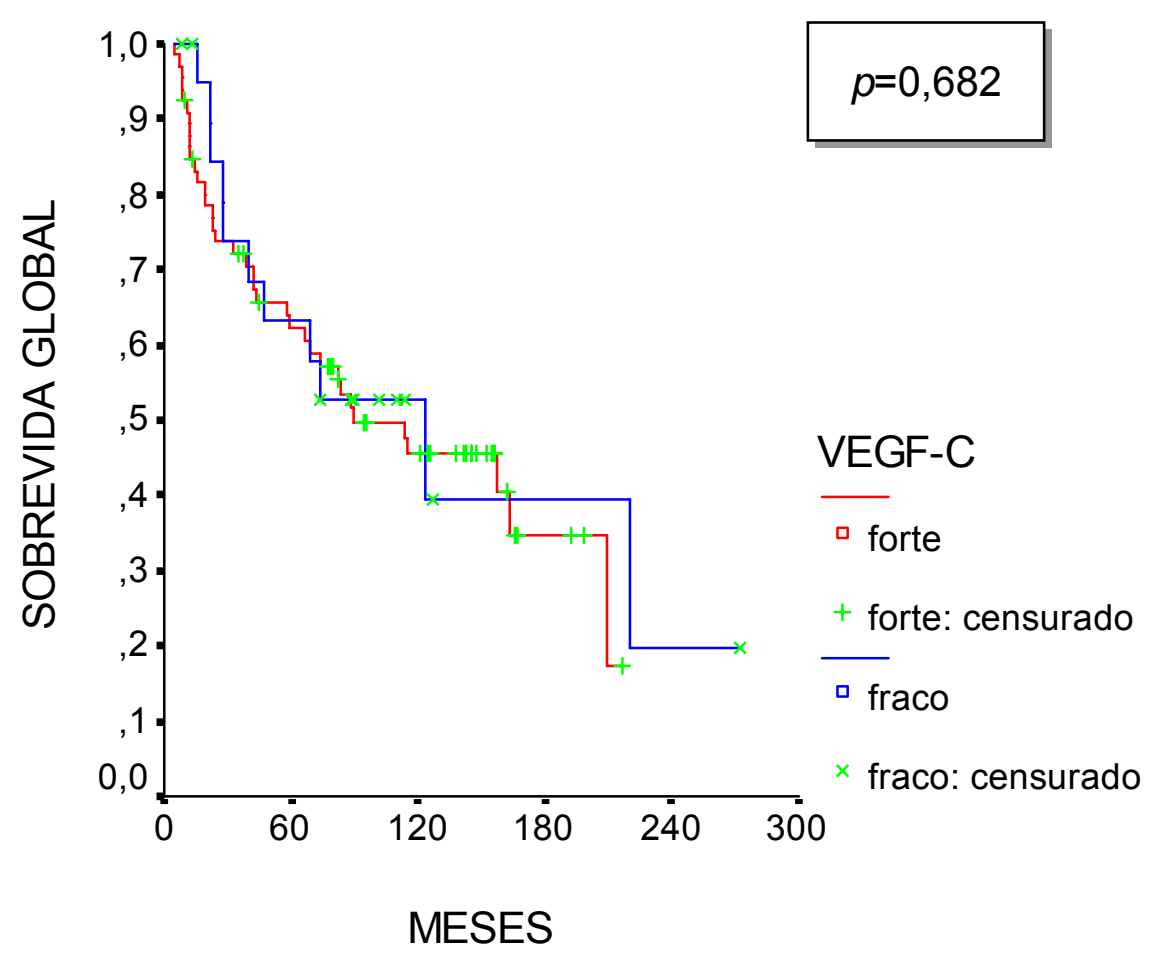

FIGURA 9- Sobrevida global dos pacientes com carcinoma espinocelular de boca de acordo com a expressão de VEGF-C. Porcentagem de sobrevida acumulada pela técnica de Kaplan-Meier. 


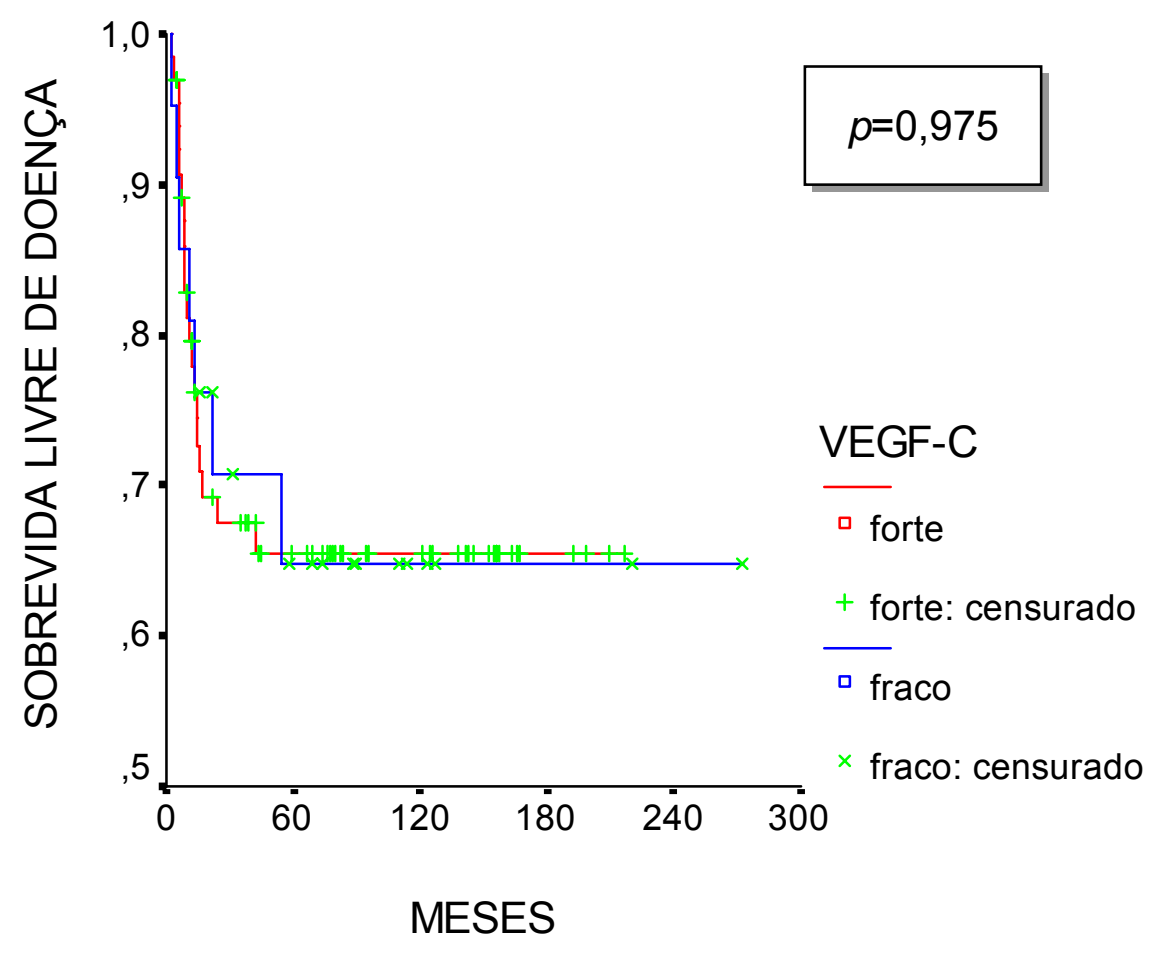

FIGURA 10-Sobrevida livre de doença dos pacientes com carcinoma espinocelular de boca de acordo com a expressão de VEGF-C. Porcentagem de sobrevida acumulada pela técnica de KaplanMeier.

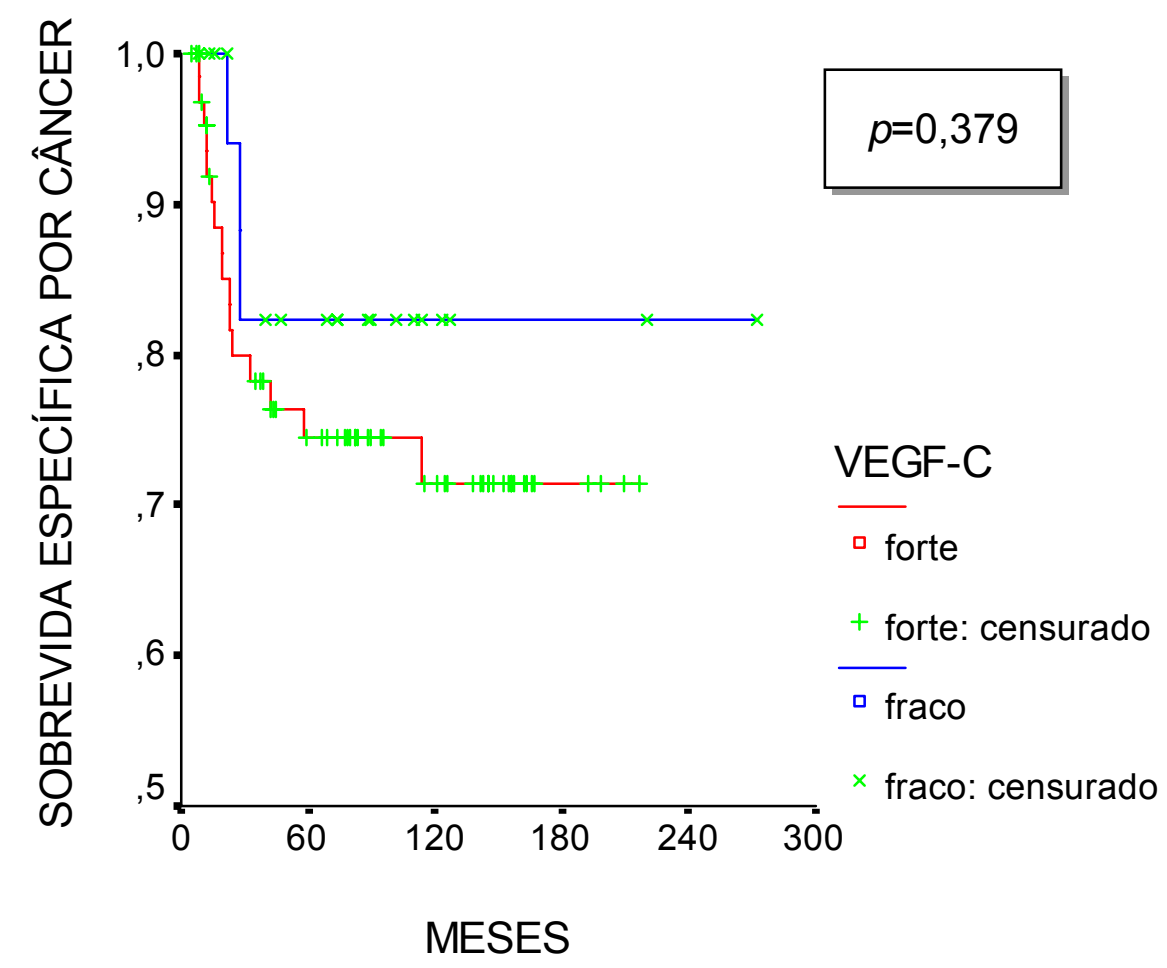

FIGURA 11-Sobrevida específica dos pacientes com carcinoma espinocelular de boca de acordo com a expressão de VEGF-C. Porcentagem de sobrevida acumulada pela técnica de Kaplan-Meier. 
Ao analisarmos a sobrevida global acumulada em cinco e dez anos com relação ao comprometimento linfonodal cervical, dos 64 pacientes com CEC de boca e submetidos ao esvaziamento eletivo do pescoço detectamos uma diferença estatisticamente significativa $(p=0,030)$ entre os grupos pN0 e pN+ (metástase oculta), como elucidado na Tabela 15 e Figura 12.

TABELA 15 -Distribuição do comprometimento linfonodal cervical histopatológico nos pacientes com carcinoma espinocelular de boca, conforme a sobrevida global para cinco e dez anos. Hospital do Câncer A. C. Camargo, São Paulo, 1968 a 2001.

\begin{tabular}{|c|c|c|c|}
\hline \multirow[b]{2}{*}{ Variável } & \multicolumn{3}{|c|}{ Sobrevida global } \\
\hline & $\begin{array}{c}5 \text { anos } \\
(\%)\end{array}$ & $\begin{array}{c}10 \text { anos } \\
(\%)\end{array}$ & $p$ \\
\hline \multicolumn{4}{|c|}{$\begin{array}{l}\text { Comprometimento } \\
\text { linfonodal }\end{array}$} \\
\hline pNo & 67,3 & 57,5 & \multirow{2}{*}{0,030} \\
\hline $\mathrm{pN}+$ & 50,0 & 28,6 & \\
\hline
\end{tabular}

p: nível descritivo do teste log-rank.

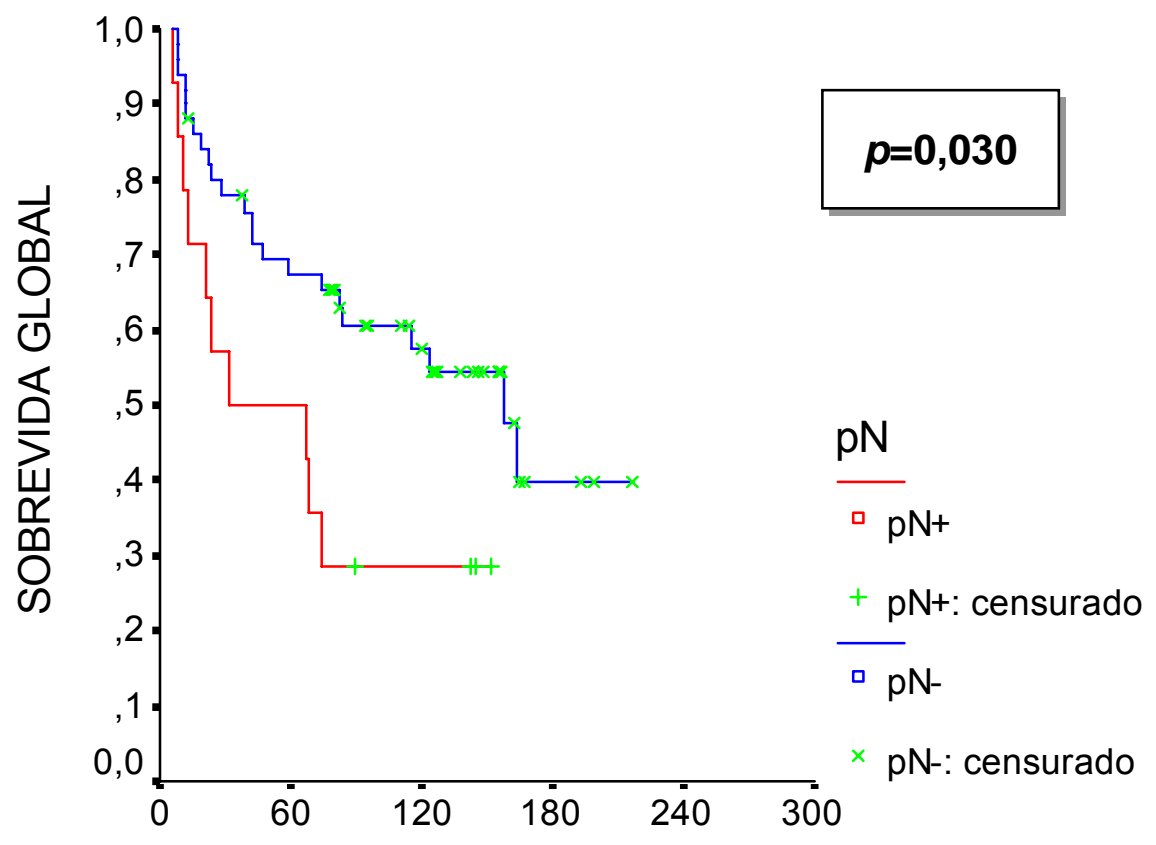

\section{MESES}

FIGURA 12-Sobrevida global dos pacientes com carcinoma espinocelular de boca de acordo com o comprometimento linfonodal cervical histopatológico. Porcentagem de sobrevida acumulada pela técnica de Kaplan-Meier. 
6 - Discussão 


\section{6 - DISCUSSÃO}

Desde as promissoras pesquisas realizadas por FOLKMAN $^{16}$ e seus colaboradores na década de setenta determinando que o crescimento e a progressão dos tumores sólidos malignos são dependentes da angiogênese, houve um incremento na busca por fatores indutores e inibidores da formação de novos microvasos sangüíneos. Além de suportar as necessidades metabólicas tumorais, os novos vasos sangüíneos servem como uma rota de escape para as células do tumor primário se disseminarem e formarem metástases ${ }^{20}$.

Com os avanços nos estudos sobre angiogênese, muitos mediadores químicos deste processo foram descobertos, destacando-se dentre estes a família VEGF, com suas diversas isoformas, algumas potentes estimuladoras não somente da angiogênese, mas também da linfangiogênese.

Nas últimas décadas, dois subtipos da família VEGF, o VEGF-C e o VEGF-D, vêm ganhando destaque na literatura como fatores de crescimento linfangiogênicos. Nos tumores sólidos malignos, como o carcinoma espinocelular, estes fatores de crescimento estão sendo associados à formação de novos vasos linfáticos e à dilatação dos pré-existentes ao atuarem sobre o receptor VEGFR-3, presente principalmente no endotélio linfático ${ }^{1,2,3,18,45,51,53,55,60,67}$.

A forte expressão de VEGF-C pelas células malignas em câncer de mama, próstata e pulmão tem sido estudada e associada ao crescimento tumoral, as metástases linfonodais e ao prognóstico dos pacientes ${ }^{7,34,35,57,65}$. Particularmente, nos carcinomas espinocelulares de cabeça e pescoço, incluindo os de boca, a forte expressão de VEGF-C vêm sendo correlacionada às metástases nos linfonodos regionais, sugerindo que esta expressão poderia contribuir na identificação de tumores com maior potencial para causar metástases linfáticas ${ }^{9,23,28,37,38,42,54,56,64,69}$. 
A ocorrência de metástase nos linfonodos cervicais permanece como um importante fator de prognóstico para os CECs de língua e assoalho de boca $23,54,56,64,69$. Entretanto, as metástases linfonodais ocultas e as micrometástases ainda são de difícil diagnóstico, mesmo com a padronização dos exames clínicos e os avanços dos métodos imaginológicos ${ }^{69}$.

Partindo da premissa de que a expressão do anticorpo anti-VEGF-C, em carcinomas espinocelulares de pacientes clinicamente N0, pudesse ser correlacionada à ocorrência de metástase oculta linfonodal $(\mathrm{pN}+)$, este fator de crescimento linfangiogênico poderia se tornar um marcador de considerável valor na identificação dos tumores com maior potencial de disseminação metastática. Com base nestas informações, o presente estudo foi idealizado visando correlacionar a expressão imuno-histoquímica do VEGF-C pelas células neoplásicas do CEC de boca, nos estádios clínicos I (T1NOM0) e II (T2NOM0), com a ocorrência de metástase oculta nos linfonodos cervicais $(\mathrm{pN}+)$ e com o prognóstico dos pacientes.

De acordo com AMARAL et al. ${ }^{5}$, 2004; KISHIMOTO et al. ${ }^{23}$, 2003; OKAMOTO et al. ${ }^{43}, 2002$ e TANIGAKI et al. ${ }^{64}$, 2004, a detecção de fatores preditivos para as metástases, principalmente aquelas ocultas nos linfonodos regionais, como proposto em nosso estudo, apresenta grande valor para aumentar as taxas de sobrevida dos pacientes, em particular, nos estádios clinicamente precoces do CEC de boca, podendo reduzir a morbidade provocada pelo esvaziamento cervical eletivo em muitos pacientes que se apresentam pNO ao exame histopatológico.

Inicialmente, a seleção da amostra foi feita com base em 176 pacientes portadores de carcinoma espinocelular de língua ou de assoalho de boca e submetidos ao tratamento no Departamento de Cirurgia de Cabeça e Pescoço e Otorrinolaringologia, do Centro de Tratamento e Pesquisa do Hospital do Câncer A. C. Camargo, São Paulo, no período de 1968 a 2001. Entretanto, após a aplicação dos critérios de inclusão e exclusão da amostra, foram selecionados 87 espécimes tumorais. 
A análise foi restrita aos CECs localizados na língua e no assoalho de boca, pois além de constituírem os sítios anatômicos mais acometidos por esta neoplasia, estas regiões são amplamente vascularizadas, favorecendo a disseminação metástatica ${ }^{13}$. Os CECs de língua e de assoalho bucal apresentam alto potencial de invasão e de comprometimento linfonodal cervical, o que prejudica o controle loco-regional da doença e interfere diretamente no prognóstico dos pacientes ${ }^{5,43}$.

Os dados clínicos e demográficos de nossa casuística revelaram um padrão já conhecido do câncer de boca no Brasil, ou seja, a maioria dos pacientes acometidos pelo carcinoma espinocelular foram homens da raça branca, com idades entre a quarta e a nona décadas de vida (Tabela 3). Este perfil assemelha-se a outros trabalhos na literatura como o de KISHIMOTO et al. $^{23}$, 2003; SEDIVY et al. ${ }^{54}$, 2003; TANIGAKI et al. ${ }^{64}$, 2004 e WARBURTON et al. ${ }^{69}, 2007$, com exceção da variável raça que não foi levantada pelos autores.

Os principais agentes etiológicos envolvidos com o câncer de boca, relacionados ao consumo de álcool e tabaco, também foram identificados, respectivamente, em $75,9 \%$ e $82,8 \%$ dos pacientes estudados (Tabela 3 ). A maioria dos pacientes desta amostra, aproximadamente $73,6 \%$, era tabagista e etilista simultaneamente (Tabela 3), reforçando que o sinergismo destes dois fatores potencializa o risco relativo para o desenvolvimento do carcinoma espinocelular na cavidade bucal ${ }^{26}$.

Quanto às características clínicas das 87 neoplasias analisadas (aproximadamente dois terços localizadas na língua e um terço no assoalho de boca), a maioria apresentava diâmetro entre dois e quatro centímetros (T2), aspecto úlcero-infiltrativo e encontravam-se restritas ao seu sítio anatômico de origem (Tabela 4). Provavelmente, o estadiamento clínico precoce (T1N0MO e T2NOM0) destas lesões se deva ao pequeno tempo de história clínica relatado pelos pacientes, pois $72,2 \%$ destes procuraram o Centro de Tratamento e Pesquisa do Hospital do Câncer A. C. Camargo, São Paulo, nos seis primeiros meses de surgimento do tumor primário (Tabela 4). 
Mesmo todos os pacientes sendo clinicamente estadiados como N0, 73,6\% foram submetidos ao esvaziamento cervical eletivo (Tabela 5) e destes, quatorze $(16,1 \%$ da amostragem) apresentaram metástases em linfonodos regionais $(\mathrm{pN}+)$ confirmadas pelo exame histopatológico (metástases ocultas). Se analisarmos a ocorrência de metástases ocultas somente nos 64 pacientes com CEC de boca submetidos ao esvaziamento linfonodal eletivo do pescoço, excluindo-se os pacientes não esvaziados, vamos constatar que a freqüência de metástase oculta aumenta para 21,9\%, sendo próxima àquelas encontradas por AMARAL et al. $^{5}(23,1 \%)$ e OKAMOTO et al. ${ }^{43}(23,7 \%)$, porém inferior à prevalência encontrada por RUSSOLO et al. ${ }^{50}(34,4 \%)$ e por BYERS et al. ${ }^{12}$ (45,0\%), em pacientes com CEC de boca.

Com relação ao tratamento dos 87 pacientes com CEC de língua e assoalho bucal, além da remoção cirúrgica inicial, 21,8\% foram submetidos à radioterapia pós-operatória adjuvante. Dos 14 indivíduos com metástase linfonodal oculta $(\mathrm{pN}+)$, a maioria, 12 pacientes, recebeu tratamento complementar radioterápico pós-operatório. De acordo com o protocolo de tratamento para CEC de boca adotado pelo Hospital A. C. Camargo, os pacientes de nossa amostra foram submetidos ao tratamento radioterápico adjuvante também por outras indicações ${ }^{47}$, incluindo margens cirúrgicas exíguas ou comprometidas, embolização vascular neoplásica e infiltração perineural.

Quando analisamos a evolução clínica dos indivíduos portadores de CEC encontramos uma freqüência de 17,2\% de recidiva local, 13,8\% de metástase regional e 2,3\% de metástase à distância. Estas taxas estão dentro dos valores esperados para os carcinomas espinocelulares de cabeça e pescoço, entretanto, estas frequências são muito variáveis nos diferentes estudos encontrados na literatura, pois geralmente as casuísticas ${ }^{54,64}$ incluem CECs com estadiamentos clínicos de T1 a T4, em diferentes sítios anatômicos e com protocolos de tratamento distintos.

Para uma melhor caracterização microscópica dos 87 carcinomas espinocelulares de língua e assoalho de boca, a graduação histopatológica de malignidade foi determinada pelo sistema proposto por BRYNE et al. ${ }^{11}$ que 
avalia o grau de queratinização, o polimorfismo nuclear, o número de mitoses, o padrão de invasão tumoral e a resposta do hospedeiro ao tumor, definida pela intensidade do infiltrado inflamatório mononuclear. A região do front de invasão nos CECs de boca foi selecionada para todas as análises microscópicas buscando sempre a porção mais profunda e representativa do fragmento tumoral. Esta região foi escolhida porque a morfologia das células malignas na porção mais invasiva do tumor, quase sempre, difere das partes mais superficiais, por apresentarem uma menor diferenciação das células neoplásicas e por conterem informações com maior valor prognóstico quando comparadas às demais áreas tumorais ${ }^{8,10,62}$.

De acordo com o índice de malignidade de BRYNE et al. ${ }^{11}$, 1989, a maioria dos carcinomas espinocelulares de boca $(79,3 \%)$ analisados foram classificados como tumores bem a moderadamente diferenciados e pouco agressivos (Tabela 7). Este perfil histopatológico para carcinomas espinocelulares da região de língua e assoalho de boca também tem sido descrito por outros autores ${ }^{23,44,56,64}$.

Como os carcinomas espinocelulares do presente trabalho eram de pequenas dimensões, com margens cirúrgicas livres (Tabela 8) e estádios clínicos iniciais, em $59,8 \%$ destes tumores de boca não foi observada a presença de embolização vascular por meio do microscópio óptico. Entretanto, as infiltrações perineural (50,6\%) e muscular (81,6\%) foram, microscopicamente, detectadas em mais da metade dos espécimes neoplásicos refletindo o potencial local de invasão tumoral (Tabela 8). A freqüência de infiltração perineural encontrada nesta casuística foi semelhante à observada por AMARAL et al. ${ }^{5}, 2004$, (48,2\%), porém bem maior do que a encontrada por LIM et al. ${ }^{29}$, 2004, (12,5\%), ambos em CECs de boca com estádios clínicos I e II.

No presente estudo, realizamos a análise da expressão imunohistoquímica do VEGF-C, no front de invasão dos 87 CECs de boca, utilizando o sistema semiquantitativo de escores proposto por SOINI et al. ${ }^{59}$, em 2001 , com uma pequena modificação na classificação do escore final. A escolha deste sistema de escores foi feita no intuito de minimizarmos a subjetividade da 
avaliação imuno-histoquímica, ao associar a porcentagem e a intensidade de células neoplásicas imunomarcadas, permitindo assim sua reprodução e comparação com os resultados de futuras pesquisas.

Nos trabalhos realizados por KISHIMOTO et al. ${ }^{23}$, 2003; SEDIVY et al. ${ }^{54}$, 2003; LÓPEZ DE CICCO et al. $^{30}$, 2004; SHINTANI et al. ${ }^{56}$, 2004 e TANIGAKI et al. ${ }^{64}$, 2004, foram utilizados diferentes sistemas de escores subjetivos e sem critérios pré-estabelecidos para determinar a porcentagem de células malignas imunomarcadas, pelo anticorpo anti-VEGF-C, nos CECs de boca. Deve ser ressaltado ainda, que estes autores avaliam a expressão do VEGF-C ou em um pequeno número de campos microscópicos ${ }^{54}$ ou percorrendo o tumor sem especificar a área analisada e o aumento microscópico utilizado. Mesmo encontrando resultados semelhantes ${ }^{23,54,30,56,64}$ com relação à expressão positiva de VEGF-C e às metástases linfonodais em carcinomas espinocelulares de boca, esta diversidade de sistemas de avaliação imuno-histoquímica pode levar a resultados tendenciosos, não refletindo o real comportamento biológico do tumor e dificultando a comparação entre os diversos estudos.

Em nossa casuística, ao analisarmos os pacientes com CEC de boca, que foram submetidos ao esvaziamento cervical eletivo, verificamos que a maioria apresentava uma forte expressão de VEGF-C, incluindo os pNO e aqueles com metástase oculta $(\mathrm{pN}+)$, bem como os pacientes que apresentaram metástase regional durante o seguimento clínico. Contrariamente aos resultados de KISHIMOTO et al. ${ }^{23}$, 2003; SEDIVY et al. ${ }^{54}$, 2003; SHINTANI et al. ${ }^{56}, 2004$; TANIGAKI, et al. ${ }^{64}, 2004$ e LI et al. ${ }^{28}, 2006$, não houve em nossa amostra correlação estatística entre o comprometimento linfonodal e a expressão imuno-histoquímica do VEGF-C pelas células malignas. Entretanto, os autores acima não investigaram a presença de metastáses ocultas em CECs de boca e a maioria destes incluíram no estudo estadiamentos clínicos de I a IV. Também não verificamos nenhuma correlação estatisticamente significativa entre a expressão de VEGF-C nos CECs de boca e as principais variáveis demográficas e clínicas relacionadas à evolução tumoral (recidiva local e metástase regional). 
Embora conflitantes com a literatura $23,28,54,56,64$ nossos resultados sugerem que a análise isolada do VEGF-C pelas células neoplásicas do CEC de boca, parece não influenciar diretamente a disseminação metastática linfonodal destes tumores malignos em estádios clínicos iniciais (I e II). Talvez nesta fase inicial, os fatores de crescimento angiogênicos, como o VEGF-C, exerçam um papel preponderante sobre os vasos sangüíneos visando muito mais suprir as necessidades metabólicas tumorais e permitir seu crescimento do que formar vias de disseminação metastática.

Sabemos que as taxas de metastáses linfonodais ocultas associadas aos CECs de língua e assoalho de boca, como demonstrado neste trabalho e em outros trabalhos ${ }^{5,12,43,50}$, são relativamente altas (>20\%) e devido a isso o esvaziamento cervical eletivo tem sido preconizado no tratamento destas neoplasias malignas. Mesmo ampliando os conhecimentos a respeito dos fatores de crescimento e dos receptores celulares necessários para a célula neoplásica metastatizar, este mecanismo ainda não está completamente esclarecido.

Embora a expressão positiva de fatores de crescimento linfangiogênicos, como o VEGF-C, nos CECs de cabeça e pescoço continue sendo associada a um aumento na densidade microvascular e à ocorrência de metástases em linfonodos regionais ${ }^{9,23,30}$, não se têm certeza se as células malignas utilizam o vasos linfáticos intratumorais neoformados para sua disseminação metastática ${ }^{51,55}$. Recentemente, a constatação de que o receptor VEGFR-3, para VEGF-C, nos tecidos adultos normais são expressos predominantemente no endotélio linfático ${ }^{27,53}$ modificou as teorias relacionadas às vias de disseminação metastática dos tumores sólidos malignos como o carcinoma espinocelular.

No passado, acreditava-se que a metástase linfática consistia em um processo passivo, no qual as células tumorais eram drenadas e atingiam os linfonodos através dos vasos linfáticos locais pré-existentes. A identificação de biomarcadores específicos para vasos linfáticos modificou este conceito, sugerindo que a linfangiogênese no interior ou na periferia dos tumores poderia ser induzida pelas células tumorais aumentando ou facilitando a disseminação 
metastática regional ${ }^{1}$. Entretanto, existe atualmente pouca evidência de que os vasos linfáticos podem proliferar nos diferentes tipos de câncer humano ${ }^{51}$. Talvez a hipótese mais consistente seja a de que VEGF-C secretado pelas células neoplásicas, estimula a expressão do seu receptor VEGFR-3 induzindo a dilatação dos vasos linfáticos peritumorais pré-existentes no tumor primário, o que facilitaria a entrada da célula maligna nestes vasos e o processo de metástase linfonodal ${ }^{19,51}$. Esta teoria claramente descrita por HOSHIDA et al. ${ }^{19}$ está ilustrada na Figura 2.

Em relação ao prognóstico, a expressão de VEGF-C pelas células malignas não influenciou as probabilidades de sobrevida global, livre de doença e específica (Tabelas 13, 14 e Figuras 9, 10, 11) dos pacientes com CECs de língua e assoalho de boca analisados. O principal fator de prognóstico estatisticamente significativo que influenciou diretamente a taxa de sobrevida global foi o comprometimento linfonodal, ou seja, a detecção das metástases ocultas (Tabela 15 e Figura 12). A sobrevida global acumulada em 5 e 10 anos foi de $67,3 \%$ e $57,5 \%$ para os pacientes pNO e de $50 \%$ e $28,6 \%$ para aqueles $\mathrm{pN}+$ sendo estas diferenças estatisticamente significativas $(p=0,030)$.

Estes resultados reforçam as afirmativas de que a detecção de metástase oculta linfonodal apresenta grande valor para aumentar as taxas de sobrevida dos pacientes $5,12,24,43,50$, em particular, nos estádios clínicos iniciais do CEC de boca. Portanto, o esvaziamento cervical eletivo permanece como uma intervenção terapêutica recomendada no tratamento destes pacientes. Todavia, a busca de fatores preditivos para metástases ocultas regionais do CEC de boca deve continuar sendo incrementada, visando reduzir a morbidade provocada pelo esvaziamento cervical eletivo em muitos pacientes que se apresentam como pNO ao exame histopatológico.

Mesmo sem obtermos nesta casuística uma correlação entre a expressão isolada de VEGF-C nos CECs de boca com as metástases ocultas e com o prognóstico dos pacientes, os fatores de crescimento linfangiogênicos, como o VEGF-C e seu receptor VEGFR-3, precisam continuar sendo investigados, pois no futuro podem se tornar alvos terapêuticos importantes contra a disseminação metastática do câncer de boca. 
7 - Conclusões 


\section{7 - CONCLUSÕES}

Analisando-se a expressão imuno-histoquímica do anticorpo antiVEGF-C pelas células malignas dos 87 pacientes com carcinomas espinocelulares, estadiamento clínico I e II, localizados na língua ou no assoalho de boca, verificamos que:

$\Rightarrow$ a maioria dos espécimes tumorais exibiram uma forte expressão do fator de crescimento endotelial vascular do tipo C (VEGF-C) na região do front de invasão tumoral;

$\Rightarrow$ nenhuma associação significativa foi observada entre a expressão de VEGF-C e as principais variáveis demográficas, clínicas, microscópicas e o índice histopatológico de malignidade tumoral;

$\Rightarrow$ não houve uma correlação estatisticamente significativa entre a expressão de VEGF-C e a ocorrência de metástases ocultas nos linfonodos cervicais $(p=0,876)$;

$\Rightarrow$ a expressão de VEGF-C não se mostrou um fator de prognóstico significativo, pois não influenciou as taxas de sobrevidas global, livre de doença e específica por câncer acumuladas em cinco e dez anos.

Detectamos ainda, que o único fator de prognóstico significativo para a sobrevida global dos pacientes com CEC de língua e assoalho de boca, clinicamente estadiados como NO e submetidos ao esvaziamento cervical eletivo, foi o comprometimento linfonodal cervical $(p=0,030)$ comprovado por exame histopatológico (metástase linfonodal oculta).

Concluímos que a expressão imuno-histoquímica isolada de VEGFC nas células malignas não influenciou a evolução clínica e o prognóstico dos pacientes com CEC de língua e assoalho de boca nos estádios iniciais (I e II) e, portanto, o esvaziamento cervical eletivo permanece como uma intervenção terapêutica recomendada no tratamento destes pacientes. 
Referências Bibliográficas 


\section{REFERÊNCIAS BIBLIOGRÁFICAS*}

1. ACHEN, M.G.; STACKER, S.A. Tumor lymphangiogenesis and metastatic spread - new players begin to emerge. Int. J. Cancer, v.119, p.1755-1760, 2006.

2. ACHEN, M.G.;MANN, G.B.; STACKER, S.A. Targeting lymphangiogenesis to prevent tumour metastasis. British J. Cancer, v.94, p.1355-60, 2006.

3. AL-RAWI, M.A.; MANSEL, R.E., JIANG, W.G. Molecular and cellular mechanisms of lymphangiogenesis. EJSO, v.31, p.117-121, 2005.

4. AMAR, Ali et al. Esvaziamento cervical seletivo no tratamento do carcinoma epidermóide do andar inferior da boca. Rev. Col. Bras. Cir., Rio de Janeiro, v.32, n.6, p.321-4, 2005.

5. AMARAL, T.M.P. et al. Predictive factors of occult metastasis and prognosis of clinical stages I and II squamous cell carcinoma of the tongue and floor of the mouth. Oral Oncol., v.40, n.8, p.780-6, 2004.

6. ARAP, M.A.; PASQUALINI, R.; ARAP, W. Mecanismos de metástase e angiogênese. In: FERREIRA, C.G.; ROCHA, J.C. Oncologia molecular. São Paulo, Atheneu, 2004. Cap.9, p.97-103.

7. ARINAGA, M et al.. Clinical significance of vascular endothelial growth factor $\mathrm{C}$ and vascular endothelial growth factor receptor 3 in patients with nonsmall cell lung carcinoma. Cancer, v.97, n.2, p.457-64, 2003.

8. BÀNKFALVI, A.; PIFFKÒ, J. Prognostic and predictive factors in oral cancer: the role of invasive tumor front. J. Oral Path. Med., v.29, n.7, p.291-8, Aug. 2000.

9. BEASLEY, N.J.P. et al. Intratumoral lymphangiogenesis and lymph node metastasis in head and neck cancer. Cancer Res., v.62, p.1315-1320, 2002.

10. BRYNE, M. Is the invasive front of an oral carcinoma the most important area for prognostication? Oral Dis., v. 4, n.2, p.70-7, 1998.

11.BRYNE, M. et al. New malignancy grading is a better prognostic indicator than Broders'grading in oral squamous cell carcinoma. J. Oral Pathol. Med., v.18, n.8, p.432-7, 1989.

12.BYERS, R.M. et al. Can we detect or predict the presence of occult nodal metastases in patients with squamous carcinoma of the oral tongue? Head Neck, v.20, n.2, p.138-44, Mar. 1998.

13.COTRAN, R.S.; KUMAR, V.; COLLINS, T. Neoplasia. In: Robbins Pathologic basis of disease. 6.ed. Philadelphia, WB Saunders, 1999. Cap.9, p.260-327.

\footnotetext{
* Normas recomendadas para uso no âmbito da Universidade de São Paulo, com base no documento Associação Brasileira de Normas Técnicas - ABNT NBR 6023/Ago. 2002.
} 
14.FERRARA, N.; DAVIS-SMYTH, T. The biology of vascular endothelial growth factor. Endocr. Rev., v.18, n.1, p.4-25, Feb. 1997.

15. FOLKMAN, J. Angiogenesis in cancer, vascular, rheumatoid and other disease. Nat. Med., 1:27-31, 1995.

16. FOLKMAN, J. Tumor angiogenesis: therapeutic implications. N. Engl. J. Med. v.285, n.21, p.1182-6, Nov. 1971.

17. FOLKMAN, J. What is the evidence that tumours are angiogenesis dependent? J. Natl. Cancer Inst., v.82, p.4-6, 1990.

18. HE, Y.; KARPANEN, T.; ALITALO, K. Role of lymphangiogenic factors in tumor metastasis. Biochim Biophys Acta, v.1654, n.1, p.3-12, Mar. 2004.

19. HOSHIDA, T. et al. Imaging steps of lymphatic metastasis reveals that vascular endothelial growth factor- $C$ increases metastasis by increasing delivery of cancer cells to lymph nodes: therapeutic implications. Cancer Res., v.66, n.16, p. 8065-75. Aug. 2006.

20.JAKÓBISIAK, M.; LASEK, W.; GOLAB, J. Natural mechanisms protecting against cancer. Immunol Lett., v.90, n.2-3, p.103-22, Dec. 2003.

21.JOHNSTONE, S.; LOGAN, R.M. The role of vascular endothelial growth factor (VEGF) in oral dysplasia and oral squamous cell carcinoma. Oral Oncol., v.42, p.337-42, 2006.

22. JOUKOV, V. et al. Proteolytic processing regulates receptor specificity and activity of VEGF-C. EMBO J., v.16, n.13, p.3898-911, Jul. 1997.

23. KISHIMOTO, K. et al. Expression of vascular endothelial growth factor-C predicts regional lymph node metastasis in early oral squamous cell carcinoma. Oral Oncol., v.39, n.4, p.391-6, Jun. 2003.

24. KOWALSKI, L.P. et al. Squamous cell carcinoma of the tongue: a review of 629 patients treated at a single institution. South-Am. J. Cancer., v.1, p. 245-54, 1997.

25.KOWALSKI, L.P.; MEDINA, J.E. Nodal metastases: predictive factors. Otolaryngol. Clin. North Am., v.31, n.4, p.621-37, Aug. 1998.

26. KOWALSKI, L.P.; NISHIMOTO, I.N. Epidemiologia do câncer de boca. In: PARISE JUNIOR, O. Câncer de boca: aspectos básicos e terapêuticos. São Paulo, Sarvier, 2000. Cap.1, p.3-11.

27. KUKK, E. et al. VEGF-C receptor binding, and pattern of expression with VEGFR-3 suggests a role in lymphatic vascular development. Development, v.122, n.12, p.3829-37, Dec. 1996.

28. LI, Q.L. et al. Expression and clinical significance of VEGF-C and Flt-4 in tongue squamous cell carcinoma. Ai Zheng., v.25, n.2, p.235-40, Feb. 2006.

29. LIM, S.C. et al. Predictive markers for late cervical metastasis in stage I and II invasive squamous cell carcinoma of the oral tongue. Clin. Cancer Res., v.10, p.166-72, Jan. 2004. 
30. LOPEZ DE CICCO, R. et al. Simultaneous expression of furin and vascular endothelial growth factor in human oral tongue squamous cell carcinoma progression. Clin. Cancer Res., v.10, n.13, p.4480-8, Jul. 2004.

31. MINISTÉRIO DA SAÚDE; SECRETARIA DE ATENÇÃO À SAÚDE; INSTITUTO NACIONAL DE CÂNCER. Tumores da cabeça e do pescoço. In: malignos. 6.ed. Rio de Janeiro, INCA, 2004. p.21-8.

32. MINISTÉRIO DA SAÚDE; SECRETARIA DE ATENÇÃO À SAÚDE; INSTITUTO NACIONAL DE CÂNCER; COORDENAÇÃO DE PREVENÇÃO E VIGILÂNCIA. Estimativa 2006: incidência de câncer no Brasil. Rio de Janeiro, INCA, 2005.

33. MORIYAMA, M. et al. Immunohistochemical study of tumour angiogenesis in oral squamous cell carcinoma. Oral Oncol., v.33, n.5, p.369-74, 1997.

34. NAKAMURA, $Y$. et al. Clinicopathological significance of vascular endothelial growth factor- $C$ in breast carcinoma with long-term follow-up. Mod. Pathol., v.16, n.4, p.309-14, 2003.

35. NAKAMURA, Y. et al.. Lymph vessel density correlates with nodal status, VEGF-C expression, and prognosis in breast cancer. Breast Cancer Res. Treat., v.91, n.2, p.125-32, 2005.

36. NAKAYA, $H$. et al. Influences of angiogenesis and lymphangiogenesis on cancerous invasion in experimentally induced tongue carcinoma. J. Oral Pathol. Med., v.34, n.2, p.87-92, Feb. 2005.

37. NAKAZATO, T. et al. Expression level of vascular endothelial growth factor$C$ and $-A$ in cultured human oral squamous cell carcinoma correlates respectively with lymphatic metastasis and angiogenesis when transplanted into nude mouse oral cavity. Oncol. Rep., v.15, n.4, p.82530, Apr. 2006.

38. NEUCHRIST, C.; EROVIC, B.M.; HANDISURYA, A. et al. Vascular endothelial growth factor $\mathrm{C}$ and vascular endothelial growth factor receptor 3 expression in squamous cell carcinomas of the head and neck. Head Neck, v.25, n.6, p.464-74, Jun. 2003.

39. NICOSIA, R.F. What is the role of vascular endothelial growth factor-related molecules in tumor angiogenesis? Am. J. Pathol., v.153, n.1, p.11-6, July 1998.

40.NÖR, J.E. et al. Vascular endothelial growth factor (VEGF)-mediated angiogenesis is associated with enhanced endothelial cell survival and induction of Bcl-2 expression. Am. J. Pathol., v.154, n.2, p.375-384, 1999.

41. NÖR, J.E.; POLVERINI, P.J. Role of endothelial cell survival and death signals in angiogenesis. Angiogenesis, v.3, n.2, p.101-16, 1999.

42. O-CHAROENRAT, P.; RHYS-EVANS, P.; ECCLES, S.A. Expression of vascular endothelial growth factor family members in head and neck squamous cell carcinoma correlates with lymph node metastasis. Cancer, v.92, n.3, p.556-68, 2001. 
43. OKAMOTO, M. et al. Prediction of delayed neck metastasis in patients with stage I/II squamous cell carcinoma of the tongue. J. Oral Pathol. Med. v.31, n.4, p.227-33, Apr. 2002.

44. OLIVEIRA, D.T. Correlação histopatológica da eosinofilia tecidual associada a tumores com o índice de malignidade em carcinomas espinocelulares de boca. Bauru, 2003. 89p. Tese (Livre Docência) Faculdade de Odontologia de Bauru, Universidade de São Paulo.

45. PEPPER, M.S. et al. Lymphangiogenesis and tumor metastasis. Cell Tissue Res., v.314, p.167-77, 2003.

46. POLVERINI, P.J.; LEIBOVICH, S.J. Induction of neovascularization in vivo and endothelial proliferation in vitro by tumor-associated macrophages. Lab Invest., v.51, n.6, p.635-42, 1984.

47. RAPOPORT, A. et al. Rastreamento, diagnóstico e tratamento do câncer de boca. São Paulo: Associação Médica Brasileira, Conselho Federal de Medicina, 2001. 12 p. Disponível em: $<$ http://www.projetodiretrizes.org.br/projeto_diretrizes/023.pdf>. Acesso em: 27 mar. 2007.

48. ROSKOSKI JR, R. Vascular endothelial growth factor (VEGF) signaling in tumor progression, Crit. Rev. Oncol./Hematol., 2007. In press.

49. RUBIN, E.; FARBER, J.L. Neoplasia. In:

Patologia. 3.ed. Rio de Janeiro, Guanabara Koogan, 2002. Cap.5, p.163-5.

50.RUSSOLO, M. et al. Prognostic indicators of occult metastases in oral cancer. Laryngoscope, v.112, p.1320-23, 2002.

51.SAHARINEN, P. et al. Lymphatic vasculature: development, molecular regulation and role in tumor metastasis and inflammation. Trends Immunol., v.25, p.387-95, 2004.

52. SCHIMMING, R. et al. Angiogenic factors in squamous cell carcinoma of the oral cavity: do they have prognostic relevance? J. Craniomaxillofac. Surg., v.32, n.3, p.176-81, 2004.

53. SCHOPPMANN, S.F. Lymphangiogenesis, inflammation and metastasis. Anticancer Res., v.25, p.4503-12, 2005.

54.SEDIVY, R. et al. Expression of vascular endothelial growth factor-C correlates with the lymphatic microvessel density and the nodal status in oral squamous cell cancer. J. Oral Pathol. Med., v.32, n.8, p.455-60, Sep. 2003.

55.SHAYAN, R.; ACHEN, M.G.; STACKER, S.A. Lymphatic vessels in cancer metastasis: bridging the gaps. Carcinogenesis, v.27, p.1729-38, 2006.

56. SHINTANI, S. et al. Expression of vascular entothelial growth factor A, B, C and $D$ in oral squamous cell carcinoma. Oral Oncol., v.40, n.1, p.13-20, Jan. 2004.

57.SKOBE, $M$. et al. Induction of tumor lymphangiogenesis by VEGF-C promotes breast cancer metastasis. Nat. Med., v.7, n.2, p.192-8, 2001.

58. SOBIN, L.H.; WITTEKIND, Ch. TNM: classification of malignant tumors. 6.ed. New York, John Wiley \& Sons, INC., 2002. 
59. SOINI, Y. et al. Endothelial nitric oxide synthase is strongly expressed in malignant mesothelioma but does not associate with vascular density or the expression of VEGF, Flk1 or Flt1. Histopathology, v.39, n.9, p.17986, 2001.

60. SU, J.L. et al. The role of the VEGF-C/VEGFR-3 axis in cancer progression. British Journal of Cancer, v.96, n.4, p.541-5, 2007.

61. SU, J.L. et al. The VEGF-C/FIt-4 axis promotes invasion and metastasis of cancer cells. Cancer Cell, v.9, n.3, p.209-23, Mar. 2006.

62. SUDBO, et al. Prognostic value of gragh theory-based tissue architecture analysis in carcinomas of the tongue. Lab. Invest., v.80, n.12, p.1881-9, Dec. 2000.

63. TAE, K. et al. Expression of vascular endothelial growth factor and microvessel density in head and neck tumorigenesis. Clin. Cancer Res., v.6, n.7, p.2821-8, July 2000.

64. TANIGAKI, Y. et al. The expression of vascular endothelial growth factor $-A$ and $-\mathrm{C}$, and receptors 1 and 3: Correlation with lymph node metastasis and prognosis in tongue squamous cell carcinoma. Inter. J. Mol. Med., v.14, n.3, p.389-95, Sep. 2004.

65. TSURUSAKI, T. et al. Vascular endothelial growth factor-C expression in human prostatic carcinoma and its relationship to lymph node metastasis. Br. J. Cancer., v.80, p.309-13, 1999.

66. UEHARA, M. et al. Expression of vascular endothelial growth factor and prognosis of oral squamous cell carcinoma. Oral Oncol., v.40, n.3, p.321-5, 2004.

67. VAN DER AUWERA, I. et al. First international consensus on the methodology of lymphangiogenesis quantification in solid human tumours. British J. Cancer, v.95, p.1611-25, 2006.

68. VEIKKOLA, T. et al. Regulation of angiogenesis via vascular endothelial growth factor receptors. Cancer Res., v.60, n.2, p.203-12, 2000.

69. WARBURTON, G. et al. Histopathological and lymphangiogenic parameters in relation to lymph node metastasis in early stage oral squamous cell carcinoma. J. Oral Maxilofac. Surg., v.65, p.475-84, 2007. 
Apêndices 
APÊNDICE A - Formulário utilizado para a coleta dos dados clínicos e microscópicos relativos aos pacientes com carcinoma espinocelular de língua e assoalho de boca, estádios clínicos I e II.

\section{Faculdade de Odontologia de Bauru - USP}

Departamento de Estomatologia - Área de Patologia

\section{Fundação Antônio Prudente / Hospital do Câncer A. C. Camargo}

Departamento de Anatomia Patológica

Departamento de Cirurgia de Cabeça e Pescoço e Otorrinolaringologia

“Expressão imuno-histoquímica de VEGF-C em pacientes portadores de carcinoma espinocelular de língua e assoalho de boca com estádios clínicos I e II"

Simone Eloiza Sita Faustino; Dra. Denise Tostes Oliveira;

Dr. Gilles Landman; Dr. Luiz Paulo Kowalski

I. Identificação e dados demográficos:

1. Número no estudo:

2. RGH:

3. Idade: anos

4. Gênero: $\square$ 1-masculino $\square$ 2-feminino

5. Raça: $\square$ 1-branca $\square$ 2-não branca

II. História clínica:

6. Tempo de história: meses (999 se desconhecido)

7. Tabagismo: $\square$ 0-não $\square$ 1-sim $\square$ 9-desc.

8. Etilismo: $\square$ 0-não $\square$ 1-sim $\square$ 9-desc.

III. Exame loco-regional:

9. Local do tumor: $\square$ 1-língua $\square$ 2-assoalho

10. Extensão do tumor: $\square$ 0-não $\square$ 1-língua $\square$ 2-assoalho $\square$ 3-gengiva $\square$ 4-retromolar 5-lábio $\square$ 6-jugal $\square$ 7-palato $\square$ 8-loja amigdaliana

11. Linha média: $\square$ 0-não compromete $\square$ 1-compromete $\square$ 9- desc.

12. Tipo de lesão: $\square$ 1-úlcero-vegetante $\square$ 2-úlcero-infiltrativa $\square$ 3-outra

13. Diâmetro aproximado da lesão: $\mathrm{cm}$

14. Estádio T (UICC 2002): $\square$ 1-T1 $\square$ 2-T2

15. Estádio N (UICC 2002): $\square$ 0-NO

IV. Cirurgia:

16. Data da cirurgia: 
17. Esvaz. cervical ipsilateral: $\square$ 0-não $\square$ 1-sim

18. Esvaz. cervical contral. (simult.): $\square$ 0-não $\square$ 1-sim

19. Data da alta hospitalar:

1

\section{Radioterapia pós-operatória:}

20. $\square$ 0-não $\square$ 1-sim

21. Data do início _________ (em branco se não fez)

22. Data do final: _________ (em branco se não fez)

\section{Análise microscópica:}

23. Número do AP:

24. Anatomopatológico do tumor primário: $\square$ 1-CEC I $\square$ 2-CEC II $\square$ 3-CEC III $\square$ 4-CEC SOE

25. Embolização vascular: $\square$ 0-não $\square$ 1-linfática $\square$ 2-sangüínea $\square$ 3-ambas $\square$ 9-ignorado

26. Infiltração perineural: $\square$ 0-não $\square$ 1-presente $\square$ 9-ignorado

27. Infiltração muscular: $\square$ 0-não $\square$ 1-presente $\square$ 9-ignorado

28. Infiltração óssea: $\square$ 0-não $\square$ 1-presente $\square$ 9-ignorado

29. Infiltração de glândulas salivares: $\square$ 0-não $\square$ 1-presente $\square$ 9-ignorado

30. Margens: $\square$ 0-livres $\square$ 1-presentes $\square$ 2-comprometidas $\square$ 9-ignorado

31. Número de linfonodos comprometidos ipsilaterais: (99 se não esv.)

32. Número de linfonodos dissecados ipsilaterais: (999 se não esv.)

33. Número de linfonodos comprometidos contralaterais: (99 se não esv.)

34. Número de linfonodos dissecados contralaterais: (999 se não esv.)

35. pN: $\square$ 0-negativo $\square$ 1-positivo $\square$ 9-sem esvaziamento cervical

\section{Evolução:}

36. Data da primeira recidiva: (em branco se não teve)

37. Locais de recidiva: $\square$ 0-não teve $\square$ 1-local $\square$ 2-pescoço ipsi $\square$ 3-pescoço contra $\square$ 4-pulmão $\square$ 5-osso $\square$ 6-fígado $\square$ 7-outra à distância recidiva, local ignorado

38. Data do diagnóstico do segundo tumor primário: (em branco se não teve)

39. Local do segundo tumor primário: (0 se não teve)

40. Data da última informação objetiva de seguimento:

41. Situação na última informação de seguimento: $\square$ 1-vivo 000

2-vivo com CA $\square$ 3-MOCI $\square$ 4MOCA $\square$ 5-MOASS $\square$ 6- perdido de vista (definição: pacientes com menos de 5 anos de seguimento e que deixaram de retornar por um período igual ao dobro estipulado. Pacientes assintomáticos perdidos após 5 anos devem ser classificados como vivo 000). 
APÊNDICE B - Número de campos e área percorrida no front de invasão para cada espécime de carcinoma espinocelular de boca.

\begin{tabular}{|c|c|c|}
\hline AP & Número de campos & $\begin{array}{l}\text { Área percorrida } \\
\text { por tumor em } \mu^{2}{ }^{2}\end{array}$ \\
\hline 70567 & 15 & 1409880,75 \\
\hline 71357 & 30 & 2819761,5 \\
\hline 78978 & 20 & 1879841 \\
\hline 117248 & 32 & 3007745,6 \\
\hline 134527 & 30 & 2819761,5 \\
\hline 156239 & 29 & 2725769,45 \\
\hline 163313 & 30 & 2819761,5 \\
\hline 164029 & 30 & 2819761,5 \\
\hline 167304 & 30 & 2819761,5 \\
\hline 171975 & 30 & 2819761,5 \\
\hline 172387 & 30 & 2819761,5 \\
\hline 173517 & 30 & 2819761,5 \\
\hline 174999 & 30 & 2819761,5 \\
\hline 176398 & 31 & 2913753,55 \\
\hline 182901 & 30 & 2819761,5 \\
\hline 183893 & 30 & 2819761,5 \\
\hline 184445 & 30 & 2819761,5 \\
\hline 191655 & 25 & 2349801,25 \\
\hline 192051 & 31 & 2913753,55 \\
\hline 193902 & 30 & 2819761,5 \\
\hline 197625 & 31 & 2913753,55 \\
\hline 199964 & 30 & 2819761,5 \\
\hline 205823 & 30 & 2819761,5 \\
\hline 208171 & 35 & 3289721,75 \\
\hline 212281 & 20 & 1879841 \\
\hline 213349 & 30 & 2819761,5 \\
\hline 215876 & 30 & 2819761,5 \\
\hline 219814 & 32 & 3007745,6 \\
\hline 220134 & 31 & 2913753,55 \\
\hline 220397 & 30 & 2819761,5 \\
\hline 226731 & 30 & 2819761,5 \\
\hline 234629 & 33 & 3101737,65 \\
\hline 237750 & 30 & 2819761,5 \\
\hline 239820 & 31 & 2913753,55 \\
\hline 241054 & 30 & 2819761,5 \\
\hline 248361 & 30 & 2819761,5 \\
\hline 250066 & 30 & 2819761,5 \\
\hline 250727 & 30 & 2819761,5 \\
\hline 253269 & 30 & 2819761,5 \\
\hline 260507 & 30 & 2819761,5 \\
\hline 261263 & 11 & 1033912,55 \\
\hline 266258 & 30 & 2819761,5 \\
\hline 266544 & 31 & 2913753,55 \\
\hline 267743 & 30 & 2819761,5 \\
\hline 267909 & 30 & 2819761,5 \\
\hline 269507 & 32 & 3007745,6 \\
\hline 270796 & 29 & 2725769,45 \\
\hline 274313 & 31 & 2913753,55 \\
\hline 274623 & 31 & 2913753,55 \\
\hline 274883 & 30 & 2819761,5 \\
\hline
\end{tabular}




\begin{tabular}{|c|c|c|}
\hline AP & Número de campos & $\begin{array}{c}\text { Área percorrida } \\
\text { por tumor } \mathrm{em} \boldsymbol{\mu m}^{2}\end{array}$ \\
\hline 276513 & 30 & 2819761,5 \\
\hline 276638 & 30 & 2819761,5 \\
\hline 289318 & 32 & 3007745,6 \\
\hline 296926 & 30 & 2819761,5 \\
\hline 297161 & 30 & 2819761,5 \\
\hline 298324 & 27 & 2537785,35 \\
\hline 301072 & 30 & 2819761,5 \\
\hline 301980 & 24 & 2255809,2 \\
\hline 301981 & 32 & 3007745,6 \\
\hline 302499 & 30 & 2819761,5 \\
\hline 302639 & 30 & 2819761,5 \\
\hline 304202 & 30 & 2819761,5 \\
\hline 304670 & 29 & 2725769,45 \\
\hline 304729 & 31 & 2913753,55 \\
\hline 308169 & 35 & 3289721,75 \\
\hline 311851 & 30 & 2819761,5 \\
\hline 317987 & 30 & 2819761,5 \\
\hline 319819 & 30 & 2819761,5 \\
\hline 331888 & 30 & 2819761,5 \\
\hline 334555 & 22 & 2067825,1 \\
\hline 335104 & 24 & 2255809,2 \\
\hline 339503 & 19 & 1785848,95 \\
\hline 340116 & 35 & 3289721,75 \\
\hline B97-00046 & 30 & 2819761,5 \\
\hline B97-00083 & 33 & 3101737,65 \\
\hline B97-04249 & 30 & 2819761,5 \\
\hline B97-07794 & 30 & 2819761,5 \\
\hline B98-00536 & 32 & 3007745,6 \\
\hline B98-00949 & 33 & 3101737,65 \\
\hline B98-03202 & 33 & 3101737,65 \\
\hline B98-09097 & 30 & 2819761,5 \\
\hline B98-09393 & 30 & 2819761,5 \\
\hline B99-06383 & 30 & 2819761,5 \\
\hline BAO-03757 & 30 & 2819761,5 \\
\hline BA0-04244 & 30 & 2819761,5 \\
\hline BA0-05770 & 35 & 3289721,75 \\
\hline \multirow[t]{2}{*}{ BA1-08966 } & 30 & 2819761,5 \\
\hline & MODA $=\mathbf{3 0}$ & ÁREA TOTAL $=241277592,4 \mu \mathrm{m}^{2}$ \\
\hline
\end{tabular}

AP: número de registro do exame anatomo-patológico do paciente 
APÊNDICE C - Distribuição dos escores de malignidade nos 87 carcinomas espinocelulares de boca, segundo o índice de malignidade, do front de invasão tumoral, de BRYNE et al. ${ }^{11}$. Hospital do Câncer A. C. Camargo, São Paulo, 1968 a 2001.

\begin{tabular}{|c|c|c|c|c|c|c|}
\hline \multirow{2}{*}{ AP } & \multicolumn{5}{|c|}{ CARACTERÍSTICAS MORFOLÓGICAS } & \multirow{2}{*}{$\mathbf{s}$} \\
\hline & $\mathbf{Q}$ & PN & M & PI & $\mathbf{R H}$ & \\
\hline 70567 & 1 & 2 & 2 & 2 & 2 & 9 \\
\hline 71357 & 2 & 1 & 2 & 1 & 1 & 7 \\
\hline 78978 & 1 & 2 & 2 & 3 & 1 & 9 \\
\hline 117248 & 1 & 1 & 2 & 4 & 1 & 9 \\
\hline 134527 & 3 & 3 & 3 & 3 & 1 & 13 \\
\hline 156239 & 1 & 1 & 1 & 2 & 1 & 6 \\
\hline 163313 & 3 & 2 & 2 & 3 & 2 & 12 \\
\hline 164029 & 1 & 2 & 1 & 2 & 3 & 9 \\
\hline 167304 & 1 & 1 & 1 & 1 & 2 & 6 \\
\hline 171975 & 2 & 1 & 2 & 2 & 1 & 8 \\
\hline 172387 & 1 & 2 & 2 & 2 & 1 & 8 \\
\hline 173517 & 1 & 2 & 2 & 2 & 2 & 9 \\
\hline 174999 & 3 & 2 & 2 & 3 & 3 & 13 \\
\hline 176398 & 1 & 1 & 2 & 2 & 3 & 9 \\
\hline 182901 & 4 & 3 & 3 & 3 & 1 & 14 \\
\hline 183893 & 3 & 1 & 2 & 2 & 1 & 9 \\
\hline 184445 & 1 & 1 & 1 & 3 & 2 & 8 \\
\hline 191655 & 2 & 2 & 3 & 3 & 3 & 13 \\
\hline 192051 & 1 & 3 & 1 & 3 & 2 & 10 \\
\hline 193902 & 1 & 1 & 1 & 1 & 2 & 6 \\
\hline 197625 & 1 & 1 & 1 & 1 & 2 & 6 \\
\hline 199964 & 3 & 3 & 3 & 3 & 1 & 13 \\
\hline 205823 & 4 & 4 & 2 & 1 & 2 & 13 \\
\hline 208171 & 2 & 3 & 2 & 2 & 1 & 10 \\
\hline 212281 & 3 & 1 & 3 & 2 & 1 & 10 \\
\hline 213349 & 3 & 3 & 2 & 2 & 3 & 13 \\
\hline 215876 & 1 & 1 & 3 & 2 & 1 & 8 \\
\hline 219814 & 3 & 3 & 3 & 2 & 2 & 13 \\
\hline 220134 & 3 & 1 & 2 & 2 & 1 & 9 \\
\hline 220397 & 2 & 1 & 2 & 2 & 1 & 8 \\
\hline 226731 & 1 & 1 & 3 & 1 & 1 & 7 \\
\hline 234629 & 3 & 1 & 2 & 2 & 2 & 10 \\
\hline 237750 & 2 & 2 & 3 & 1 & 1 & 9 \\
\hline 239820 & 1 & 1 & 2 & 2 & 3 & 9 \\
\hline 241054 & 1 & 1 & 2 & 2 & 1 & 7 \\
\hline 248361 & 2 & 2 & 2 & 3 & 2 & 11 \\
\hline 250066 & 3 & 2 & 2 & 3 & 2 & 12 \\
\hline 250727 & 4 & 3 & 2 & 3 & 3 & 15 \\
\hline 253269 & 2 & 3 & 3 & 3 & 1 & 12 \\
\hline 260507 & 3 & 3 & 3 & 3 & 3 & 15 \\
\hline 261263 & 3 & 2 & 3 & 1 & 1 & 10 \\
\hline 266258 & 2 & 1 & 2 & 2 & 1 & 8 \\
\hline 266544 & 2 & 1 & 2 & 2 & 2 & 9 \\
\hline 267743 & 2 & 1 & 2 & 2 & 1 & 8 \\
\hline
\end{tabular}




\begin{tabular}{|c|c|c|c|c|c|c|}
\hline \multirow{2}{*}{ AP } & \multicolumn{5}{|c|}{ CARACTERÍSTICAS MORFOLÓGICAS } & \multirow{2}{*}{$\mathbf{S}$} \\
\hline & $\mathbf{Q}$ & PN & M & $\mathbf{P I}$ & RH & \\
\hline 267909 & 1 & 1 & 2 & 1 & 1 & 6 \\
\hline 269507 & 2 & 2 & 2 & 2 & 1 & 9 \\
\hline 270796 & 1 & 1 & 2 & 2 & 2 & 8 \\
\hline 274313 & 4 & 3 & 2 & 3 & 2 & 14 \\
\hline 274623 & 2 & 1 & 3 & 1 & 2 & 9 \\
\hline 274883 & 2 & 1 & 3 & 2 & 1 & 9 \\
\hline 276513 & 2 & 2 & 3 & 2 & 1 & 10 \\
\hline 276638 & 4 & 3 & 2 & 3 & 2 & 14 \\
\hline 289318 & 3 & 1 & 3 & 1 & 2 & 10 \\
\hline 296926 & 2 & 2 & 2 & 3 & 2 & 11 \\
\hline 297161 & 3 & 2 & 2 & 3 & 2 & 12 \\
\hline 298324 & 3 & 1 & 1 & 1 & 2 & 8 \\
\hline 301072 & 2 & 2 & 3 & 2 & 2 & 11 \\
\hline 301980 & 3 & 2 & 2 & 2 & 1 & 10 \\
\hline 301981 & 2 & 1 & 1 & 2 & 1 & 7 \\
\hline 302499 & 3 & 3 & 2 & 3 & 1 & 12 \\
\hline 302639 & 4 & 4 & 2 & 3 & 3 & 16 \\
\hline 304202 & 3 & 1 & 1 & 2 & 1 & 8 \\
\hline 304670 & 2 & 1 & 2 & 2 & 1 & 8 \\
\hline 304729 & 2 & 1 & 2 & 3 & 3 & 11 \\
\hline 308169 & 2 & 3 & 2 & 2 & 1 & 10 \\
\hline 311851 & 2 & 2 & 1 & 2 & 3 & 10 \\
\hline 317987 & 2 & 2 & 2 & 2 & 1 & 9 \\
\hline 319819 & 2 & 2 & 2 & 2 & 2 & 10 \\
\hline 331888 & 3 & 2 & 2 & 3 & 2 & 12 \\
\hline 334555 & 4 & 1 & 1 & 1 & 2 & 9 \\
\hline 335104 & 2 & 3 & 1 & 2 & 2 & 10 \\
\hline 339503 & 4 & 4 & 2 & 2 & 1 & 13 \\
\hline 340116 & 2 & 2 & 2 & 2 & 2 & 10 \\
\hline B97-00046 & 1 & 2 & 2 & 3 & 2 & 10 \\
\hline B97-00083 & 3 & 3 & 4 & 3 & 1 & 14 \\
\hline B97-04249 & 1 & 2 & 2 & 3 & 2 & 10 \\
\hline B97-07794 & 1 & 3 & 3 & 3 & 2 & 12 \\
\hline B98-00536 & 1 & 1 & 3 & 2 & 2 & 9 \\
\hline B98-00949 & 1 & 1 & 1 & 2 & 3 & 8 \\
\hline B98-03202 & 4 & 2 & 1 & 3 & 2 & 12 \\
\hline B98-09097 & 4 & 2 & 3 & 3 & 3 & 15 \\
\hline B98-09393 & 4 & 2 & 3 & 2 & 2 & 13 \\
\hline B99-06383 & 3 & 2 & 2 & 2 & 1 & 10 \\
\hline BA0-03757 & 3 & 3 & 2 & 3 & 2 & 13 \\
\hline BA0-04244 & 1 & 2 & 2 & 2 & 1 & 8 \\
\hline BA0-05770 & 2 & 1 & 2 & 2 & 2 & 9 \\
\hline BA1-08966 & 3 & 2 & 2 & 2 & 1 & 10 \\
\hline
\end{tabular}


Anexo 
ANEXO A - $\quad$ Aprovação da Comissão de Ética em Pesquisa do Centro de Tratamento e Pesquisa do Hospital do Câncer A. C. Camargo

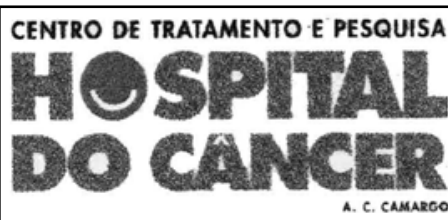

São Paulo, 30 de novembro de 2005.

À

Dra. Simone Eloiza Sita Faustino

Ref.: Projeto de Pesquisa n. 0 746/05

"Influência do VEGF-C e da densidade de vasos linfáticos nas metástases linfonodais e no prognóstico de pacientes com carcinoma espinocelular de boca".

Prezada Doutora:

Seu projeto de pesquisa, acima mencionado, foi apreciado pela Comissão de Ética em Pesquisa (CEP) do Hospital do Câncer em sua reunião de 29/11/2005. Os membros desta comissão aprovaram a realização deste estudo.

Informações a respeito do andamento do referido projeto deverão ser encaminhadas à secretaria do CEP dentro de 12 meses.

Atenciosamente,

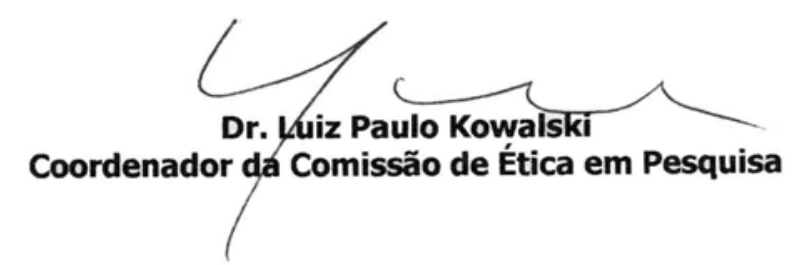

c.c

Orientadora: Profa. Dra. Denise Tostes Oliveira

Colaboradores: Dr. Luiz Paulo Kowalski / Dr. Gilles Landman 